\title{
COMPORTAMENTO DO ÓLEO DE SOJA REFINADO UTILIZADO EM FRITURA DE IMERSÃO EM RESTAURANTE UNIVERSITÁRIO
}

ROSENEIDE CRISTINA FERRAZ CELLA

Nutricionista

Orientadora: Prof ${ }^{\mathrm{a}}$. Dr ${ }^{\mathrm{a}}$. MARISA APARECIDA BISMARA REGITANO D'ARCE

\begin{abstract}
Dissertação apresentada à Escola Superior de Agricultura "Luiz de Queiroz", Universidade de São Paulo, para obtenção do título de Mestre em Ciências, Área de concentração: Ciência e Tecnologia de Alimentos.
\end{abstract}

PIRACICABA

Estado de São Paulo - Brasil

Setembro - 2000 
ERRATA

ROSENEIDE CRISTINA FERRAZ CELLA. Comportamento do óleo de soja refinado utilizado em fritura de imersão em restaurante universitário.

\begin{tabular}{|c|c|c|c|c|}
\hline p. & item & linha & onde se lê & leia-se \\
\hline $\mathrm{i}$ & 3.2 .1 .1 & Vigésima terceira & 28 & 29 \\
\hline ii & 5 & Vigésima segunda & 67 & 66 \\
\hline ii & $\begin{array}{l}\text { Referências } \\
\text { bibliográficas }\end{array}$ & Vigésima terceira & 68 & 67 \\
\hline vii & Resumo & $\begin{array}{l}\text { segunda, oitava e } \\
\text { décima sétima }\end{array}$ & $\begin{array}{l}\ldots \text {... teste de aceitabilida- } \\
\text { de... }\end{array}$ & ... teste hedônico... \\
\hline 19 & 2.5 & $\begin{array}{l}\text { Décima e décima } \\
\text { primeira }\end{array}$ & 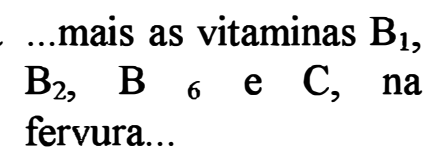 & $\begin{array}{l}\ldots \text { mais as vitaminas } B_{1} \\
B_{2}, B_{6} \text { e } C \text {, do que na } \\
\text { fervura ... }\end{array}$ \\
\hline 22 & 2.7 & Quinta & $\begin{array}{l}\text {.. por preferência ou } \\
\text { gosto por um item } \\
\text { especifico do alimento. }\end{array}$ & $\begin{array}{lll}\ldots \text { por } & \text { preferência } & \text { ou } \\
\text { gosto } & \text { global } & \mathrm{do} \\
\text { alimento. } & & \end{array}$ \\
\hline
\end{tabular}

$28 \quad 3.1 .3 \quad$ Vigésima quarta e através do teste de através do teste vigésima quinta aceitabilidade, ... hedônico (Peryan \&

31 3.3.1 Décima nona $\quad$ Teste de aceitabilidade $\quad \begin{aligned} & \text { Giardot, 1952) } \\ & \text { Teste hedônico }\end{aligned}$

31 3.3.1 Vigésima $\quad O$ teste de aceitabilida- $A$ análise sensorial foi de foi realizado no... realizada através do teste hedônico no...

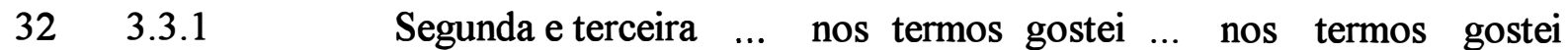
muitísssimo (9) e des- extremamente (9) e desgostei muitíssimo (1). gostei extremamente (1).

32 3.3.1 Terceira e quarta Calculou-se o índice...e Excluir as linhas.

a média definiu o índice de aceitabilidade.

$\begin{array}{lll}32 & 3.4 & \text { Sétima }\end{array}$

$42 \quad 4.1 .5 \quad$ Primeira ... dos dados do teste ... dos dados do teste de aceitabilidade,... hedônico,... ... do teste de acei- ... do teste hedônico da tabilidade da fritura de fritura de vegetais. vegetais

$50 \quad 4.2 .5 \quad$ Nona

$51 \quad 4.2 .5 \quad$ Primeira ... o teste de aceitabi- ... o teste hedônico foi lidade foi conduzido... conduzido... ... do teste de acei- ... do teste hedônico da tabilidade da fritura de fritura de peixe. peixe

64 4.3.5 Nona Médias das notas do Médias das notas do $\begin{array}{lll}66 & 5 & \text { Sétima }\end{array}$

77 Apêndice-2 Décima oitava ..teste de aceitabilidade ... teste hedônico. REFERENCIA BIBLIOGRÁFICA, acrescentar na página 72 PERYAM, D.R.; GIRARDOT, N.F. Advanced taste test method. Food Engineering, v. 24, p. 58-61, 1952. 


\title{
Dados Internacionais de Catalogaçāo na Publicação (CIP) DIVISÃo DE BIBLIOTECA E DOCUMENTAÇĀO - Campus "Luiz de Oueiroz"/USP
}

\author{
Cella, Roseneide Cristina Ferraz \\ Comportamento do óleo de soja refinado utilizado em fritura de imersão em \\ restaurante universitário / Roseneide Cristina Ferraz Cella. - - Piracicaba, 2000. \\ $77 \mathrm{p}$.
}

Dissertação (mestrado) - - Escola Superior de Agricultura Luiz de Queiroz, 2000. Bibliografia.

1. Fritura de imersão 2. Óleo de soja refinado 3. Restaurante I. Título

CDD 664.369

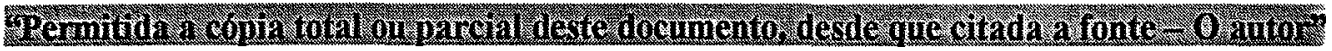


Eu não sei de quase nada, mas duvido de muita coisa.

(Guimarães Rosa) 


\section{AGRADECIMENTOS}

À minha familia e, principalmente ao meu marido Nelson e aos meus filhos Rafael e Paula pelo incentivo, apoio e compreensão;

À minha orientadora Marisa A.B. Regitano d'Arce, pelo incentivo, amizade e dedicação durante toda a realização do curso de mestrado e elaboração do trabalho da dissertação;

À Marta Helena Fillet Spoto pela colaboração, amizade e apoio na análise sensorial;

Aos funcionários do restaurante universitário da ESALQ - USP, especialmente d̀ responsável do serviço de alimentação, Maria Luiza Marcuz de Souza Campos;

Aos funcionários do Departamento de Agroindústria, Alimentos e Nutrição especialmente à técnica do Laboratório de Óleos e Gorduras, Maria Fernanda de Almeida Prado;

Às minhas ex-alunas e técnicas em nutrição e dietética, Roselene Valota e Valquiria Procópio, pela colaboração na coleta das amostras do óleo;

À bibliotecária Beatriz Helena Giongo pela correção das referências bibliográficas;

À Deborah Gonçalves de Oliveira e à Cargil, pelas análises de cor Lovibond e apoio;

À todos os participantes da análise sensorial;

E a todos que contribuiram direta ou indiretomente para a execução deste trabalho. 


\section{SUMÁRIO}

Página

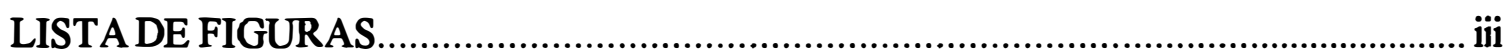

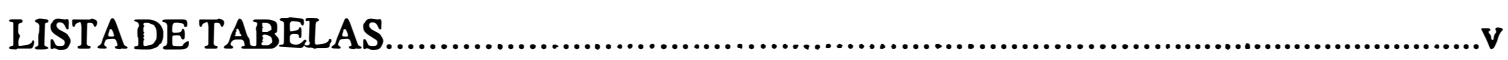

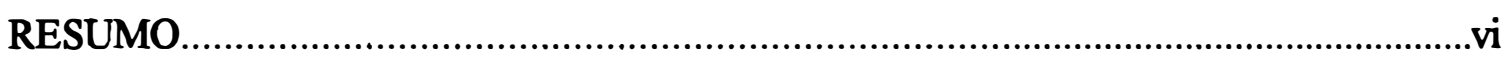

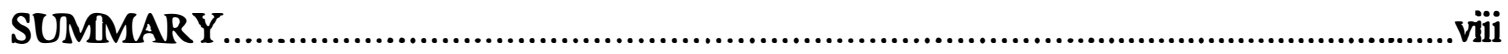

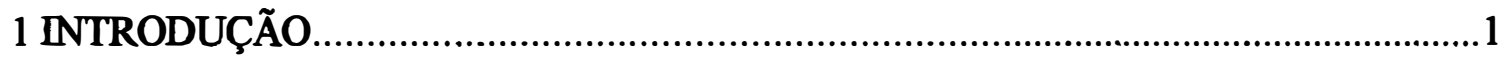

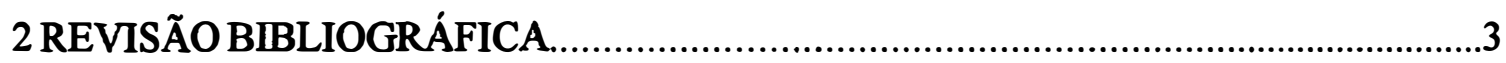

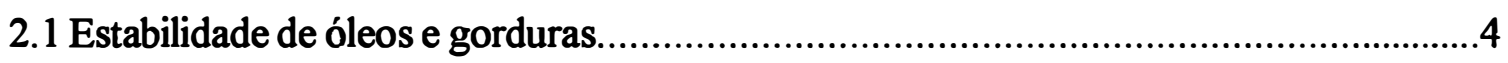

2.2 Alterações fisicas, químicas, térnnicas e organolépticas..........................................5

2.3 Fatores que influenciam a qualidade da fritura....................................................

2.4 Métodos de avaliação da ocorrência de oxidação e perda da qualidade....................12

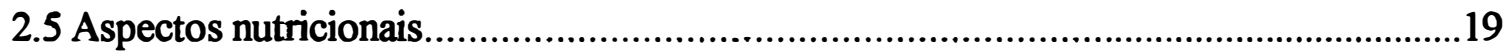

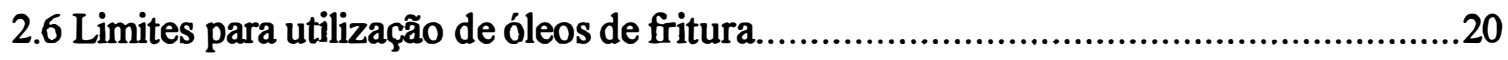

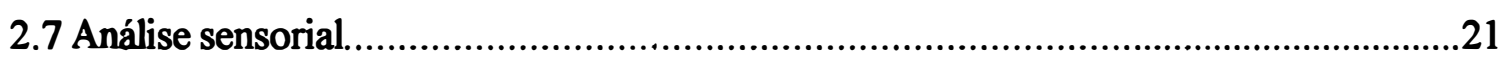

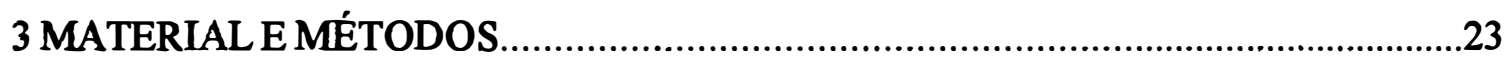

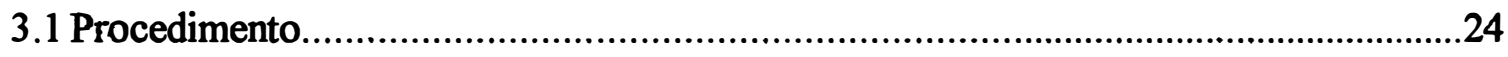

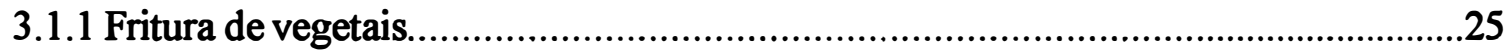

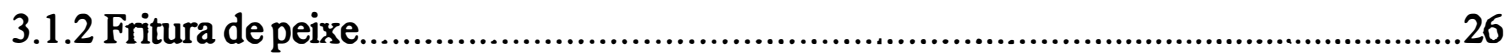

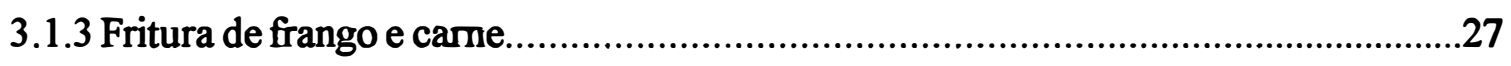

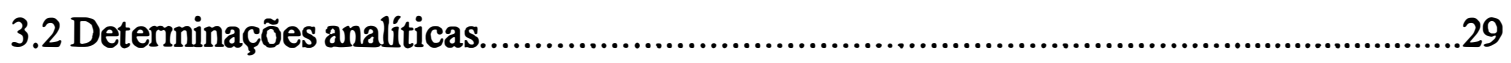

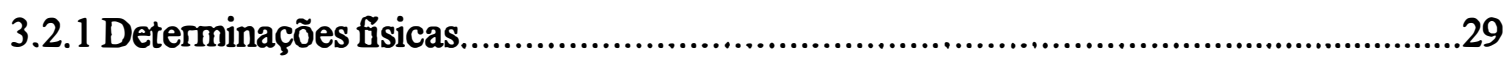

3.2.1.1 Absortividade em $232 \mathrm{~nm}$ e em $270 \mathrm{~nm}$..............................................28

3.2.1.2 Espectro de absortividade na faixa do espectro ultravioleta-220 nm a $320 \mathrm{~nm} .29$

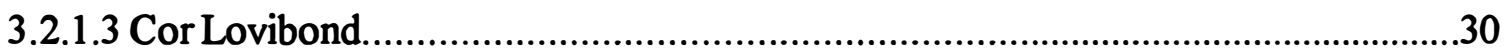

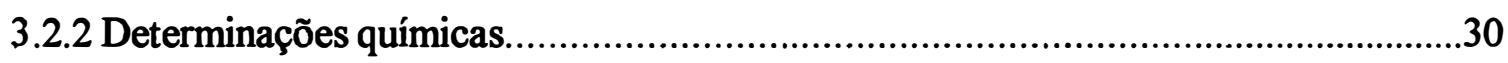

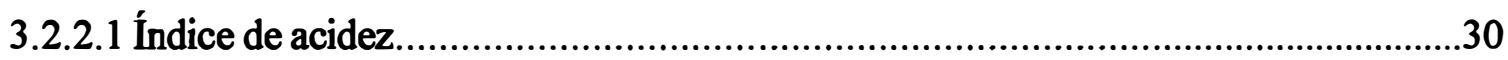

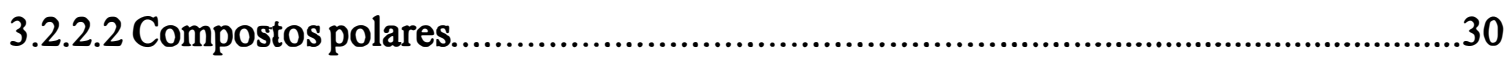

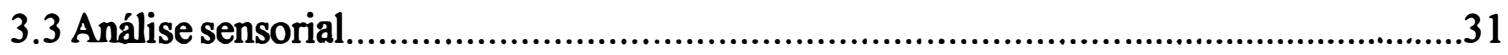




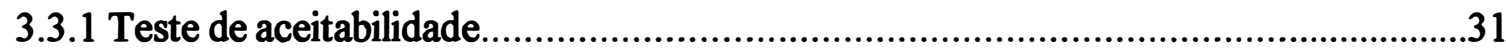

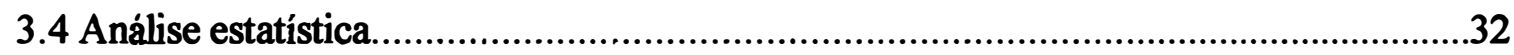

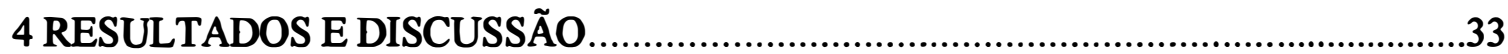

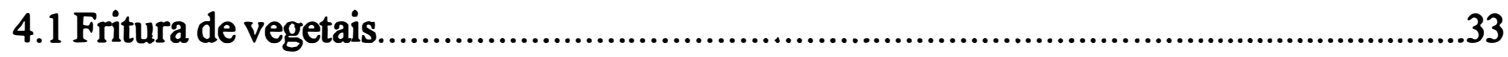

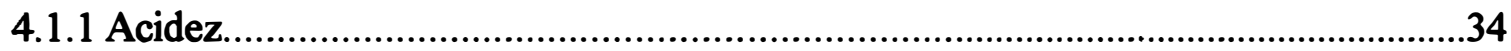

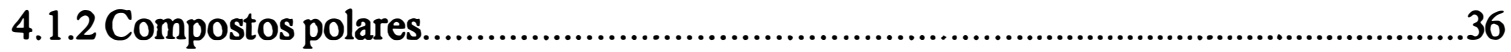

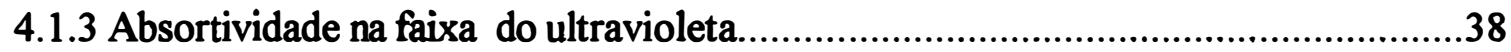

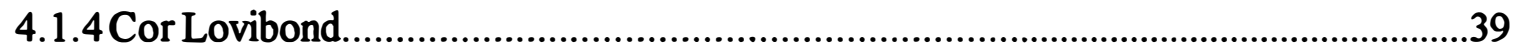

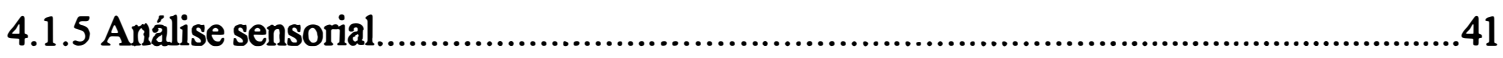

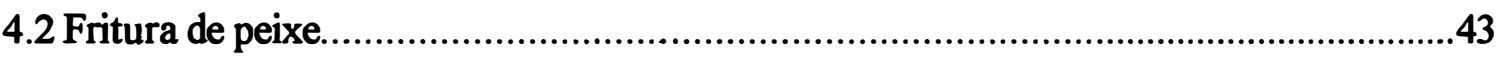

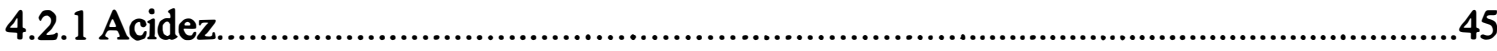

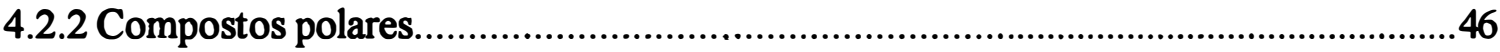

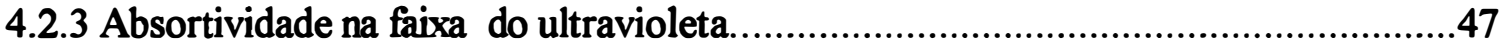

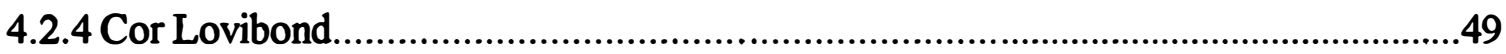

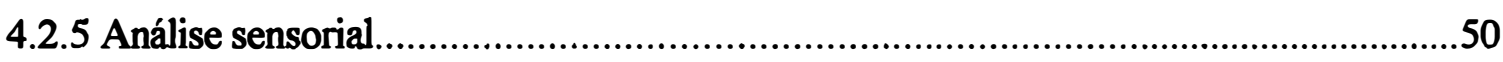

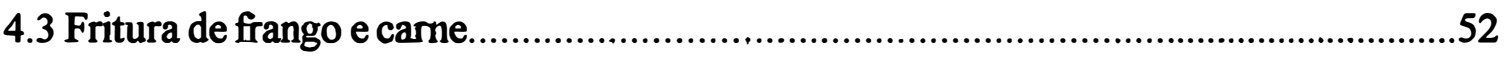

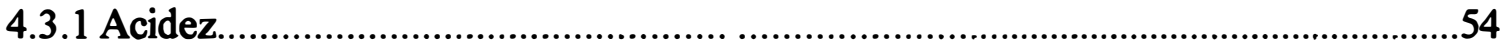

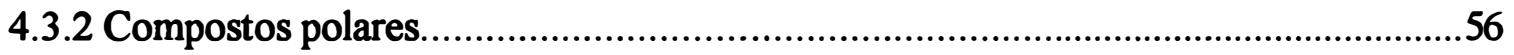

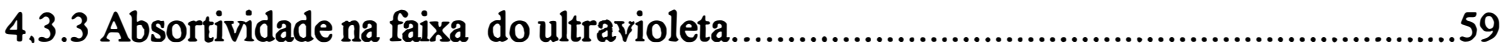

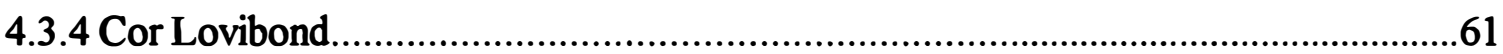

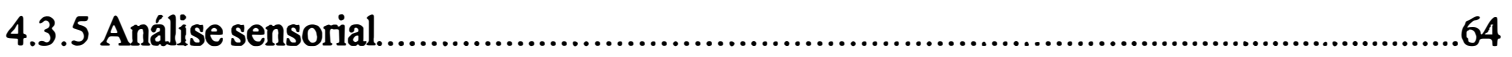

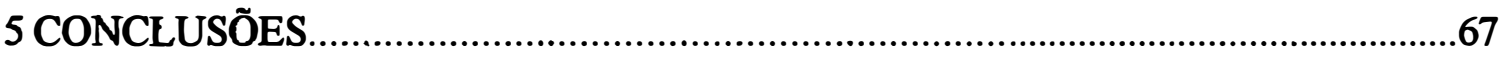

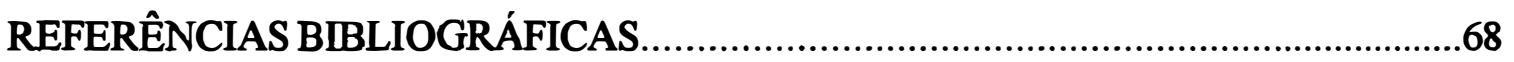

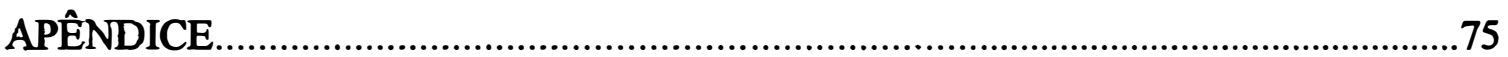




\section{LISTA DE FIGURAS}

Página

1 Produtos de decomposição em frituras com gordura............................................ 7

2 Índice de acidez no óleo da fritura de vegetais................................................... 35

3 Teor dos compostos polares no óleo da fritura de vegetais................................. 37

4 Correlação entre o teor de compostos polares e o índice de acidez no óleo da

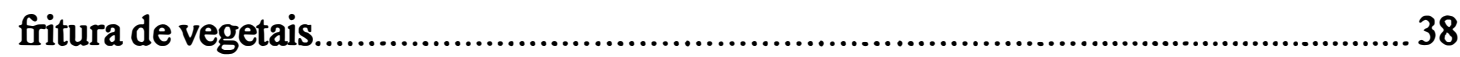

5 Espectro de absortividade na faixa do UV no óleo da fritura de vegetais............... 39

6 Cor Lovibond no óleo da fritura de vegetais................................................... 40

7 Correlação entre índice de acidez e cor Lovibond no óleo da fritura de vegetais........41

8 Comportamento dos provadores em relação à aceitabilidade da fritura de vegetais....42

9 Índice de acidez no óleo da fritura de peixe................................................... 45

10 Teor dos compostos polares no óleo da fritura de peixe....................................... 46

11 Correlação entre o teor de compostos polares e o índice de acidez no óleo da

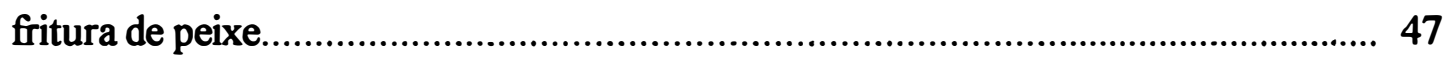

12 Espectro de absortividade na faixa do UV no óleo da fritura de peixe.................. 48

13 Cor Lovibond no óleo da fritura de peixe...................................................... 49

14 Correlação entre índice de acidez e cor Lovibond no óleo da fritura de peixe...... 50

15 Comportamento dos provadores em relação à aceitabilidade da fritura de peixe.... 51

16 Índice de acidez no óleo A da fritura de frango e carne ....................................... 55

17 Índice de acidez no óleo B da fritura de frango e carne ..................................... 55

18 Teor dos compostos polares no óleo A da fritura de frango e carne.................... 57

19 Teor dos compostos polares no óleo B da fritura de frango e carne .................... 57

20 Correlação entre o teor de compostos polares e o índice de acidez no óleo A da

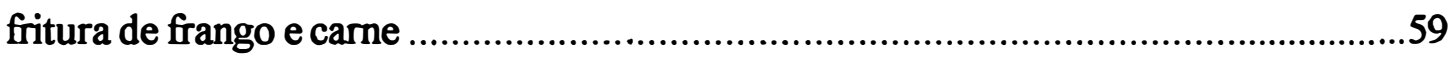

21 Correlação entre o teor de compostos polares e o índice de acidez no óleo B da

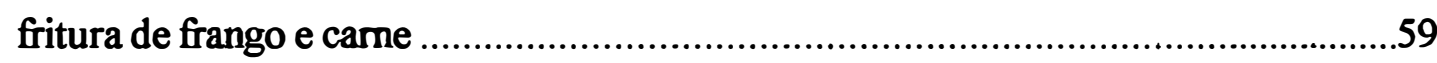

22 Espectro de absortividade na faixa do UV no óleo A da fritura de frango e carne ....60

23 Espectro de absortividade na faixa do UV no óleo B da fritura de frango e came ....60 
24 Cor Lovibond no óleo A da fritura de frango e carne ..................................... 62

25 Cor Lovibond no óleo B da fritura de frango e carne ....................................... 62

26 Correlação entre o índice de acidez e cor Lovibond no óleo A da fritura de

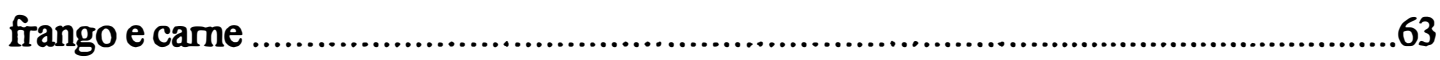

27 Correlação entre o índice de acidez e cor Lovibond no óleo B da fritura de

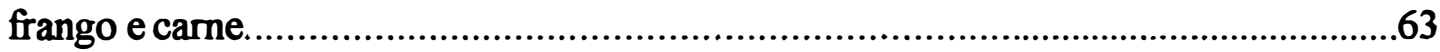

28 Comportamento dos provadores em relação à aceitabilidade da fritura de

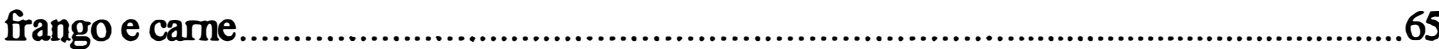




\section{LISTA DE TABELAS}

Página

1 Balanço mundial de óleo de soja, safra 1999/00.............................................. 4

2 Máxima absorção dos principais grupos cromóforos dos produtos da oxidação....... 14

3 Métodos analíticos baseados em mudanças físicas e químicas............................. 16

4 Programa de utilização do óleo de soja e os alimentos empregados na fritura

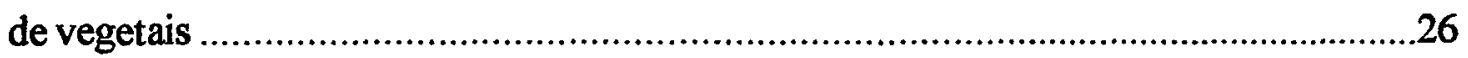

5 Programa de utilização do óleo de soja na fritura de peixe......................................27

6 Programa de utilização do óleo de soja e a quantidade de frango e carne

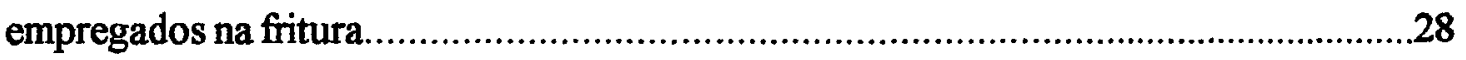

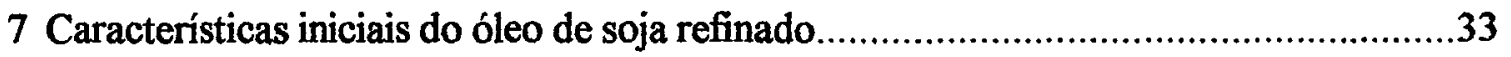

8 Características do. óleo de soja durante a fritura de vegetais.....................................34

9 Médias das notas do teste de aceitabilidade da fritura de vegetais....................... 42

10 Características do óleo de soja durante a fritura de peixe........................................44

11 Médias das notas do teste de aceitabilidade da fritura de peixe................................51

12 Características iniciais dos óleos de soja A e B.......................................... 52

13 Características do óleo de soja A durante a fritura de frango e carne................. 53

14 Características do óleo de soja B durante a fritura de frango e carne .................... 54

15 Médias das notas do teste de aceitabilidade da fritura de frango e carne............... 64 


\title{
COMPORTAMENTO DO ÓLEO DE SOJA REFINADO UTILIZADO EM FRITURA DE IMERSÃO EM RESTAURANTE UNIVERSITÁRIO
}

\author{
Autora: ROSENEIDE CRISTINA FERRAZ CELLA
}

Orientadora: Prof ${ }^{a}$. Dr $^{\mathrm{a}}$. MARISA APARECIDA BISMARA REGITANO-D'ARCE

\section{RESUMO}

A fritura de alimentos é uma preparação de grande aceitabilidade por conferir aos alimentos características de odor, sabor, cor e textura, que os tornam mais atraentes para o consumo. Dependendo do alimento a ser frito, quantidades de óleo ou gordura, que variam de 10 a $40 \%$, podem ser absorvidos pelo alimento, tornando-o um ingrediente do alimento. Devido ao conhecimento de que o processo de fritura altera a natureza química do óleo aquecido, estudou-se o comportamento do óleo de soja refinado em fritura de imersão intermitente, em três categorias de alimentos: de origem vegetal, de peixe e de frango e carne, sob temperatura controlada entre $170^{\circ} \mathrm{C} \mathrm{e} 180^{\circ} \mathrm{C}$, em restaurante universitário. No experimento foram utilizadas 275 latas de $900 \mathrm{ml}$ que correspondem a 248 litros de óleo soja refinado para fritar $1.453 \mathrm{~kg}$ de alimentos, a saber: $808 \mathrm{~kg}$ de frango (coxa e sobrecoxa), $12 \mathrm{~kg}$ de carne bovina (bife), $260 \mathrm{~kg} \mathrm{de}$ pescado (filé de merluza) e $373 \mathrm{~kg}$ de diferentes vegetais crus, como batata, couve-flor e abobrinha, além de mandioca cozida. Analisou-se o óleo através de análises fisicas (absortividade na faixa do espectro ultravioleta e cor Lovibond) e químicas (índice de 
acidez e compostos polares). A análise sensorial foi realizada nos alimentos fritos através do teste de aceitabilidade. No Brasil não existem normas e regulamentos para descarte do óleo utilizado, portanto, utilizou-se como limite de alteração a regulamentação da Espanha, 25\% de compostos polares, e dos EUA, 1\% para ácidos graxos livres (\% expressos em ácido oléico). Os resultados obtidos após 30h35min da fritura de vegetais foram: indice de acidez, 0,282, compostos polares, $18,8 \%$, cor Lovibond, 14/2,0 (Y/R ), absortividade em $232 \mathrm{~nm}$ de 9,213 e absortividade em $270 \mathrm{~nm}$ de 2,293; a média do teste de aceitabilidade no último período foi de 7,96. Na fritura de peixe após o período de 16h50min os resultados foram: índice de acidez, 0,473, compostos polares, 17,1\%, cor Lovibond em 16h20 min, 70/6,3 (Y/R), absortividade em $232 \mathrm{~nm}$ de 7,988 e absortividade em $270 \mathrm{~nm}$ de 1,978; a média do teste de aceitabilidade em $16 \mathrm{~h} 20 \mathrm{~min}$ foi de 7,4 . Somente a fritura de frango e carne foi realizada com duas marcas diferentes de óleo de soja refinado, que foram identificadas como A (o mesmo óleo dos ensaios anteriores) e B. Os resultados da fritura A após 17 horas foram os seguintes: índice de acidez, 0,471 , compostos polares, $19,9 \%$, cor Lovibond, $70 / 7,1$ (Y/R), absortividade em $232 \mathrm{~nm}$ de 6,569 e absortividade em $270 \mathrm{~nm}$ de 1,415; a média do teste de aceitabilidade em 15 horas foi de 7,6. Para o óleo de fritura $B$, no mesmo período, os resultados obtidos foram: índice de acidez, 0,497, compostos polares, 19,5\%, cor Lovibond em 15 horas, 70/8,1 (Y/R), absortividade em $232 \mathrm{~nm}$ de 8,575 e absortividade em $270 \mathrm{~nm}$ de 1,590. De acordo com os resultados obtidos, o aquecimento do óleo levou a alterações hidroliticas e oxidativas, que não chegaram a recomendar o seu descarte, mostrando que o óleo de soja submetido a essas condições de fritura pode ser usado pelo período do estudo. 


\title{
REFINED SOYBEAN OIL PERFORMANCE IN DEEP FAT FRYING IN COLLEGE CAFETERIA MEALS
}

\author{
Author: ROSENEIDE CRISTINA FERRAZ CELLA
}

Adviser: Prof ${ }^{a}$. Dr ${ }^{a}$. MARISA APARECIDA BISMARA REGITANO-D'ARCE

\section{SUMMARY}

Deep fat frying of food is an important way of preparation for attributing to the fried product characteristics of flavor, color and texture, that turn them more attractive for the consumption. Depending on the fried food, amounts of oil or fat absorbed vary from 10 to $40 \%$, turning them into an ingredient of the food. The frying process alters the oil chemical nature. The refined soybean oil performance under intermittent deep fat frying conditions of three food class: vegetables, fish, chicken and beef, in the college cafeteria, at temperatures maintained between $170^{\circ} \mathrm{C}\left(338^{\circ} \mathrm{F}\right)$ and $180^{\circ} \mathrm{C}\left(356^{\circ} \mathrm{F}\right)$, was studied. During this study, 248 liters of soy oil were used to process $1.453 \mathrm{~kg}$ of foods as: $808 \mathrm{~kg}$ chicken, $12 \mathrm{~kg}$ beef, $260 \mathrm{~kg}$ fish and $373 \mathrm{~kg}$ vegetables: potato, cauliflower, squash and cassava. The oil loss of quality was monitored by means of physical (absorptivity at $232 \mathrm{~nm}$ and $270 \mathrm{~nm}$ and Lovibond color) and chemical (free fatty acids, polar compounds contents) determinations. Sensorial analysis in the deep fat 
fried foods was performed through the acceptability test. In Brazil laws and regulations for discarding the used oil do not exist, therefore, the alteration limit used was $25 \%$ polar compounds as used in Spain and 1\% free fatty acids (\% expressed in oleic acid) as is in the USA. The results obtained after a period of 30 hours and 35 minutes for vegetables frying were $0.282 \%$ free fatty acids, $18.8 \%$ polar compounds, $14 / 2.0$ (Y/R) for Lovibond color, 9.213 absorptivity at $232 \mathrm{~nm}$ and 2.293 absorptivity at $270 \mathrm{~nm}$, and an average of 7.96 for the acceptability test in the period. The results obtained after a period of 16 hours and 50 minutes for fish frying were $0.473 \%$ free fatty acids, $17.1 \%$ polar compounds, 70/6.3 (Y/R) for Lovibond color, 7.988 absorptivity at $232 \mathrm{~nm}$ and 1.978 absorptivity at $270 \mathrm{~nm}$, and an average of 7.4 for the acceptability test in period the 16 hours and 20 minutes. Chicken and beef frying was conducted with two brands of refined soybean oil, identified as $A$ (the same of the previous study) and B, for a period of 17 hours. The results for oil A frying were $0.471 \%$ free fatty acids, $19.9 \%$ polar compounds, 70/7.1 (Y/R) for Lovibond color, 6.569 absorptivity at $232 \mathrm{~nm}$ and 1.415 absorptivity at $270 \mathrm{~nm}$, and an average of 7.6 for the acceptability test after a period of 15 hours. The results for oil B frying were $0.497 \%$ free fatty acids, $19.5 \%$ polar compounds, 70/8.1 (Y/R) for Lovibond color after a period of 15 hours, 8.575 absorptivity at $232 \mathrm{~nm}$ and 1.590 absorptivity at $270 \mathrm{~nm}$. From the results obtained one can conclude that the oil heating conditions under study promoted both hydrolytic and oxidative alterations, however they did not reach the discarding level. 


\section{INTRODUÇÃo}

As gorduras fazem parte da constituição de muitos alimentos, sendo também utilizadas no preparo de uma infinidade de outros. São ingredientes importantes, que têm propriedade de realce do sabor $e$ aroma dos alimentos, são utilizados como meio de cocção, aumentam o valor energético, presença de vitaminas lipossolúveis e ácidos graxos essenciais, contribuem para a saciedade dos alimentos além de participarem de importantes funções metabólicas (Griswold, 1972).

O rápido crescimento de diferentes setores consumidores de óleos nos últimos anos se deve à modificação nos hábitos alimentares em países industrializados. 0 mercado de alimentos fritos no Brasil tem apresentado uma tendência de grande crescimento, com a entrada crescente de lojas e grandes redes de "fast-food" (Parra, 1995).

Atualmente, a maior parte dos óleos e gorduras comestiveis é consumida após ser submetida a elevadas temperaturas em processos como a fritura e o forneamento.

A principal razão que leva o processo de fritura a ser destacado é que, durante o processo, não só o óleo se incorpora ao alimento para modificar positivamente 
suas propriedades nutricionais e sensoriais, como também atua como meio de transferência de calor reutilizável, muito mais eficiente que o forneamento e muito mais rápido do que o cozimento em água. Assim, as altas temperaturas que se utilizam, ao redor de $180^{\circ} \mathrm{C}$, produzem uma acelerada penetração de calor levando a uma rápida preparação dos alimentos, algo sumamente necessário nestes tempos modernos (Jorge, 1996).

O processo de fritura desenvolve características de odor, sabor, cor e textura que tornam os alimentos mais atraentes para o consumo (Lima \& Gonçalves, 1995). Além disso, considerando que uma parte do óleo utilizado como meio de transferência é absorvida pelo alimento, tornando-se um ingrediente do produto, verifica-se a necessidade do uso de um meio de fritura de alta qualidade e a manutenção desta qualidade pelos períodos mais longos possíveis.

Devido ao conhecimento de que o processo de fritura altera a natureza química do óleo aquecido, pesquisas têm sido feitas para que determine se o consumo de alimentos fritos representa riscos à saúde e para que se conheça o comportamento dos óleos vegetais sob as diferentes condições de equipamentos e tipo de alimento frito.

Este estudo visou acompanhar através das determinações analíticas e sensoriais as alterações oxidativas no óleo de soja durante vários ciclos de aquecimento ou fritura, de três classes de alimentos, em restaurante universitário. 


\section{REVISÃO BIBLIOGRÁFICA}

A soja constitui uma fonte de óleo e proteína, com grande diversidade de usos, tanto agrícolas como industriais. No setor de óleos vegetais comestiveis, o óleo de soja conquistou uma grande participação no mercado brasileiro. Em 1993, de cada 10 latas consumidas, 9 eram de óleo de soja, ocupando posição de destaque, tanto no panorama internacional como no interno (Rohr, 1993).

A produção de soja no Brasil tem aumentado nos últimos anos. $\mathrm{O}$ alto valor comercial desta leguminosa rica em proteínas é devido ao aumento da participação do consumo na alimentação humana e animal em todo o mundo (Buzzetti, 1998).

O Brasil teve uma safra de soja (99/2000) de mais de 30 milhões de toneladas, configurando como o segundo maior produtor mundial da oleaginosa, responsável por cerca de $20 \%$ da produção mundial de soja. O país é o segundo maior exportador mundial de grãos, farelo e óleo de soja (Abiove, 2000).

Segundo o Agrianual (2000) a produção mundial do óleo de soja é da ordem de 23 milhões de toneladas. O Brasil é o segundo produtor mundial (Tabela 1). 
Tabela 1. Balanço mundial de óleo de soja, safra 1999/00* em mil toneladas métricas

\begin{tabular}{lcccc}
\hline \multicolumn{1}{c}{ Países } & Produção & Consumo & Importação & Exportação \\
\hline Estados Unidos & 8.394 & 7.144 & - & 907 \\
Brasil & 3.840 & 2.700 & 200 & 1.340 \\
Argentina & 2.570 & - & - & 2.450 \\
China & 1.768 & 3.198 & 1.300 & - \\
\hline
\end{tabular}

Fonte: Departamento de Agricultura dos Estados Unidos (USDA), segundo Agrianual (2000).

Previsão*

O óleo de soja é o produto mais utilizado em preparações de cozinhas industriais devido ao seu baixo custo para o mercado consumidor e a sua elevada produção agrícola (Canziani, 1995).

\subsection{Estabilidade de óleos e gorduras}

Labuza (1971) descreveu a oxidação lipídica como uma das principais causas de deterioração dos alimentos, por isso a necessidade do uso de antioxidantes.

A autoxidação por efeito da luz sobre os ácidos graxos insaturados é uma das alterações mais significativas em óleos, gorduras e alimentos gordurosos. $\mathrm{O}$ método de evitar sua ação seria o uso de uma barreira de luz sobre o alimento através de uma embalagem, atuando como bloqueio dos componentes da onda de luz (Espinoza-Atencia \& Faria, 1994).

A estabilidade é a resistência à oxidação de óleos e gorduras, e uma forma de determinar o comportamento futuro do produto. A estabilidade oxidativa é conhecida como a resistência do ácido graxo insaturado à formação de hidroperóxidos (Barrera - 
Arellano, 1993).

Inúmeros fatores determinam a estabilidade de óleos e gorduras, destacando-se a composição química e as condições do processo de refino. As etapas mais importantes são a de clarificação e desodorização. Na fritura ocorre uma diminuição da estabilidade pela aceleração da oxidação, devido às altas temperaturas usadas e aos compostos pró-oxidantes presentes nos alimentos submetidos a este processo (Moretto \& Barrera - Arellano, 1995).

\subsection{Alterações físicas, químicas, térmicas e organolépticas}

Durante o processo de fritura, o óleo é exposto a três agentes que causam mudanças em sua estrutura: água proveniente do próprio alimento, que leva a alterações hidrolíticas; oxigênio que entra em contato com o óleo, levando a alterações oxidativas; e, finalmente, a temperatura em que o processo ocorre, resultando em alterações térmicas (Gonçalves, 1997).

A hidrólise é uma das mais importantes reações químicas que acontecem durante o processo de fritura, envolvendo a quebra de ligações éster no glicerídeo com formação de ácidos graxos livres, monoglicerídeos, diglicerideos e glicerol. A hidrólise ocorre devido à presença de água; quanto maior o percentual de água no alimento, mais rapidamente ela deve ocorrer. Os produtos da hidrólise podem ser voláteis e são quimicamente mais reativos (Berger, 1984).

A oxidação é um processo degradativo que ocorre quando o oxigênio atmosférico ou aquele que está dissolvido no óleo reage com ácidos graxos insaturados presentes. As reações químicas envolvidas no processo de oxidação de óleos são muito complexas e geram, em seus estágios mais avançados, produtos organolepticamente inaceitáveis, ou seja, com odores e sabores estranhos (Hellin \& Clausell, 1984). Como 
resultados desta reação há a formação de hidroperóxidos, produtos primários da oxidação (Melton et al., 1994).

Finalmente, a termoxidação é outra via importante de degradação dos óleos e gorduras em que produtos das reações de hidrólise e oxidação, catalisadas pelas altas temperaturas, interagem produzindo dímeros, polímeros, monômeros cíclicos e outros compostos de degradação. Estes compostos são usualmente divididos em duas categorias: os compostos voláteis (CV) e os compostos não voláteis (CNV) (Figura 1) (Dobarganes \& Pérez-Camino, 1989).

Os compostos voláteis, por natureza, são eliminados durante o processo de fritura por volatilização, arrastados pelo vapor liberado dos alimentos em fritura, e estão relacionados com as características organolépticas do óleo e do próprio alimento frito. Os compostos não voláteis são formados principalmente de reações de oxidação e termoxidação, são de grande interesse tanto do ponto de vista nutricional, já que farão parte da dieta, como também do ponto de vista analítico, acumulando-se desde o princípio do processo e só são removidos do óleo por absorção nos alimentos de fritura (Melton et al., 1994). 


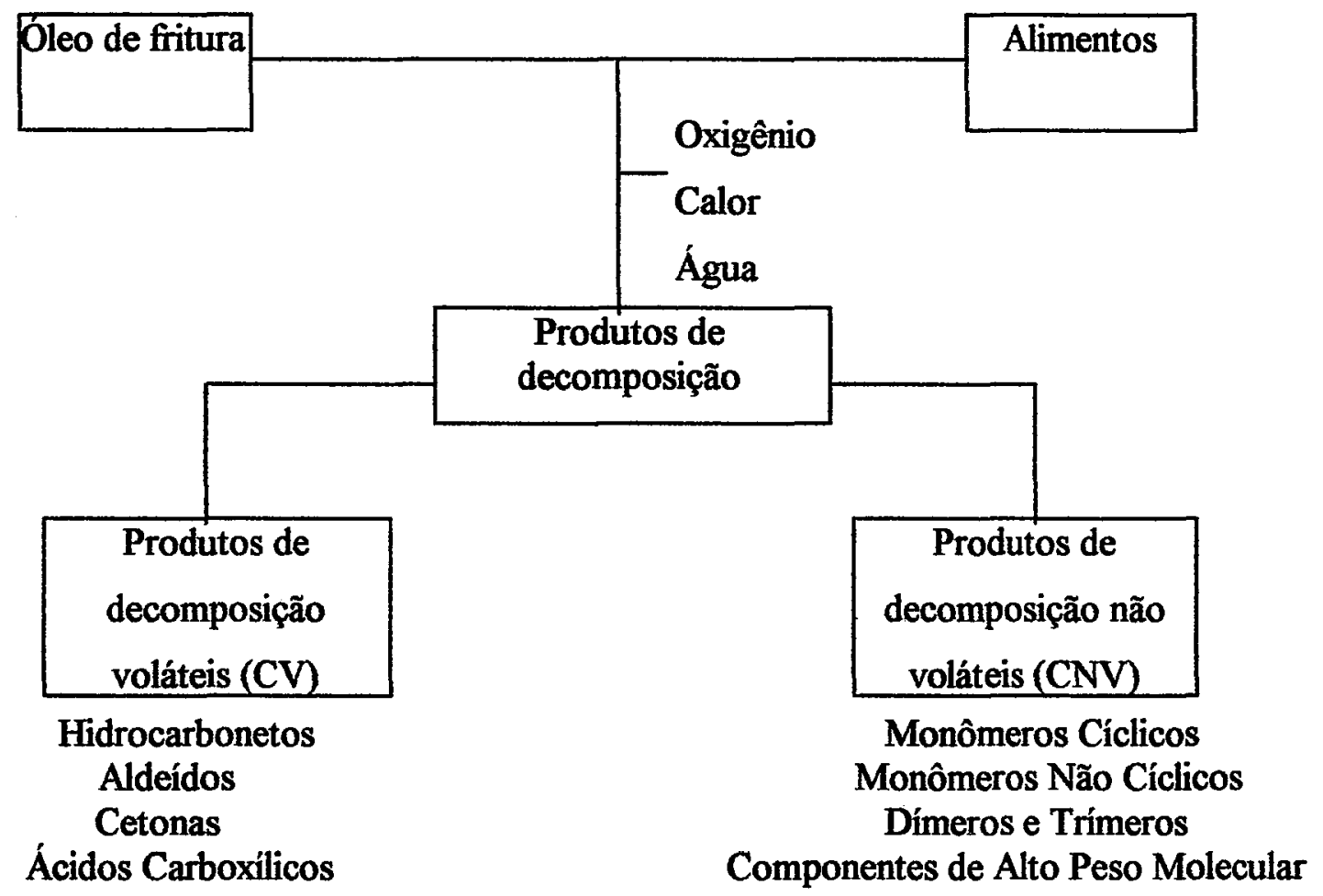

Figura 1- Produtos de decomposição em frituras com gorduras (Brooks, 1991)

No processo de fritura, a água do alimento desempenha um papel importante, ela capta energia térmica do óleo quente que rodeia o alimento, evitando que se queime ou carbonize por excessiva desidratação. Mesmo que o óleo esteja a $180^{\circ} \mathrm{C}$, a temperatura do alimento se mantém a $100^{\circ} \mathrm{C}$. $\mathrm{O}$ calor é conduzido desde a superficie em contato com o óleo até o interior do alimento, fazendo com que este cozinhe (Blumenthal, 1991).

Lima \& Gonçalves (1995) descreveram os diferentes estágios de degradação do óleo, a partir do momento em que se inicia o aquecimento para preparação dos alimentos. $\mathrm{Na}$ fase inicial não existem produtos de alteração no óleo, os baixos níveis de surfactantes existentes limitam o contato óleo/alimento, o óleo é 
afastado pela camada de vapor que circunda o alimento resultando na preparação de alimentos mais claros, com o interior bem cozido, fracos odores de fritura e pouca absorção de óleo. Com algumas horas de fritura, ocorre alguma conversão de triglicerídeos originais (aproximadamente $3 \%$ ) formando polímeros, mono $\mathrm{e}$ diglicerídios, ácidos graxos livres e produtos de oxidação, com quantidades mínimas de surfactantes, melhorando seu cozimento e o produto frito fica ligeiramente mais tostado e a superficie um pouco mais crocante. Em seqüência, com o tempo de fritura, um pequeno excesso de surfactantes formados melhora o cozimento, mas permite que quantidades de óleo maiores penetrem no alimento, qualquer óleo adicionado nesta fase retarda, mas não previne a progressão da degradação do óleo, pois neste ponto o óleo adicionado interage imediatamente com os radicais livres e produtos de oxidação já existentes, a cor do alimento frito torna-se dourada, sua superficie mais crocante, e este adquire aroma característico de fritura. $\mathrm{Na}$ fase de óleo em degradação, as reações de oxidação se tornam avançadas levando à formação de moléculas complexas, algumas voláteis, que liberam odores desagradáveis. $\mathrm{O}$ alimento frito torna-se de baixa qualidade, sua superficie muito endurecida, com manchas e excessiva quantidade de óleo absorvida. Na fase de descarte do óleo, a taxa de hidrólise encontra-se muito avançada e os produtos de oxidação acumulam-se no óleo, gera-se muita fumaça e pode ainda conter compostos tóxicos. A qualidade do produto frito cai muito, apresenta vida de prateleira curta e "flavor" desagradável, o centro do alimento não cozinha totalmente, sua superficie se torna muito dura e escura e há absorção excessiva de óleo.

\subsection{Fatores que influenciam a qualidade da fritura}

A qualidade do refino do óleo é um ítem importante. A presença de insaturações e qualidade inicial baixa favorecem as chamadas "reações degradativas". Os óleos menos insaturados se oxidam mais lentamente e, por isso, têm vida útil maior, e por isso a gordura parcialmente hidrogenada, possui maior estabilidade, têm vida útil maior, sendo largamente utilizada especialmente em indústria de alimentos fritos (Gonçalves, 1997). 
A natureza do alimento frito altera a qualidade do óleo. Alimentos com alto teor de água podem aumentar a velocidade das reações hidrolíticas. Além disso, o óleo pode ser contaminado por gorduras do próprio alimento, ou por gorduras presentes em alimentos pré-processados. A relação entre a área superficial e o peso do alimento influencia diretamente a quantidade de óleo que penetra no alimento (Obretenov, 1993).

$\mathrm{Na}$ fritura é importante manter a qualidade do óleo e a velocidade de reposição, que é descrita como a proporção da quantia total do óleo de fritura e da velocidade com que o óleo fresco é adicionado à fritadeira. A recomendação diária da reposição é de 15 a $25 \%$ da capacidade da fritadeira (Stevenson et al., 1984).

Cuesta e Muniz (1998) avaliaram o efeito da reposição de óleo fresco em diferentes óleos usados em fritura repetidas de batatas, quantificando os compostos polares isolados por cromatografia de coluna e por cromatografia de alta performance de exclusão. Os resultados indicaram que com a freqüente rotatividade de óleo fresco, 0 nível de $25 \%$ de compostos polares é raramente alcançado, e existem poucos problemas com a deterioração deste óleo.

A temperatura de fritura muito baixa favorece a estabilidade do óleo, mas o alimento ficará muito oleoso, temperatura muito elevada, o alimento ficará muito cozido por fora e cru por dentro, acarretando também outras alterações no óleo de fritura. A temperatura ideal é $180^{\circ} \mathrm{C}$ (Gonçalves, 1997).

As frituras devem ser realizadas à menor temperatura possivel (usualmente $180-185^{\circ} \mathrm{C}$ ), sem variações bruscas. Para isso, deve-se dispor de um bom termostato (Monferrer \& Villata, 1993). É aconselhável, para evitar o superaquecimento do óleo, estabelecer correntes de convecção, ou simplesmente, agitar o cesto da fritadeira durante a fritura. 
Segundo Fedeli (1988), a velocidade de degradação de um óleo é proporcional à temperatura de aquecimento e ao tempo de duração da fritura.

$\mathrm{Na}$ fritura industrial de alimentos os fatores que mais influenciam na qualidade final do processo são: qualidade inicial e grau de insaturação da gordura, conteúdo lipídico inicial e final do alimento e relação superficie/volume, temperatura, tempo e tipo de aquecimento utilizados na fritadeira (Parra, 1995).

Os óleos e gorduras expostos ao oxigênio sob altas temperatura (superior a $180^{\circ} \mathrm{C}$ ) podem ter ação deletéria, os peróxidos formados são instáveis, eles se decompõem rapidamente e conseqüentemente apresentam baixo índice de peróxido, todavia, contém os produtos de decomposição dos peróxidos e outros resultantes de reações secundárias, como: os hidroxi-ceto-aldeído e epoxi-ácidos, aldeídos e cetonas (Moretto \& Alves, 1986).

A fritura é um processo dinâmico em que a temperatura do óleo varia conforme a adição do alimento e os processos de evaporação da água e absorção da gordura (Cuesta \& Muniz, 1994).

Perkins et al. (1965) estudaram os efeitos dos processos de fritura, sob condições práticas. Foram efetuadas experiências que determinaram o efeito do aquecimento contínuo, quantidade de óleo renovada, aquecimento intermitente, adição de vapor de água. Os resultados obtidos indicaram que a quantidade de material polimérico formada aumentou regularmente com o tempo de aquecimento. $O$ ato de fritar um produto alimentício como, por exemplo, a batata, ou a simples adição de água ao óleo quente, exerceu um efeito deteriorativo intenso sobre o óleo de algodão estudado.

Segundo Peers \& Swoboda (1982), o tipo de aquecimento também é decisivo, para a qualidade do óleo, se descontínuo, provoca maior degradação que o 
aquecimento contínuo. Em temperatura elevada, as reações tem lugar, principalmente, na superficie de contato com o ar, enquanto que durante o resfriamento, ao diminuir a velocidade da oxidação, a solubilidade do ar aumenta, favorecendo a entrada de oxigênio na massa levando à formação de hidroperóxidos e radicais livres.

Os equipamentos de aço inoxidável são mais indicados, pois não participam das alterações em óleo de fritura. Devem apresentar facilidade de limpeza, pois o óleo polimerizado, que deposita nas paredes, tende a catalisar reações que levam a alterações no óleo (Berger, 1984).

O efeito da relação superficie/volume deve ser considerado, pois quanto maior a superficie do óleo em contato com o ar, maior a taxa de reações de alteração. Para compensar as perdas de absorção de óleo pelo alimento frito a adição de óleo novo é necessária, mas neste caso o óleo novo se deteriora rapidamente devido ao efeito catalítico dos produtos de degradação presentes no óleo usado (Fritsch, 1981).

O uso intermitente tem maior influência sobre a qualidade do óleo, isto é, os períodos curtos de uso são mais destrutivos que os longos, devido à formação de peróxidos e a sua decomposição durante os ciclos de resfriamento e reaquecimento. Atribui-se este efeito ao aumento de absorção de oxigênio durante o resfriamento do óleo, favorecendo reações oxidativas (Fritsch, 1981).

A qualidade do óleo e da gordura usadas na fritura é importante em relação à qualidade do alimento frito. A quantidade de óleo absorvido em diferentes alimentos fritos é variável: peixe ou frango à doré absorvem aproximadamente $15 \%$ de óleo, enquanto peixe ou frango à milanesa absorvem aproximadamente $20 \%$ de óleo. As batatas chips tradicionais absorvem de 35 a $40 \%$ de óleo. Modernas tecnologias estão sendo introduzidas para produzir batatas chips com teores de óleo de $20 \%$ (Rossel, 1998). 
Segundo Stevenson et al. (1984), a gordura absorve a umidade do alimento proporcionando a formação da camada externa (crosta), da mesma maneira, que pode provocar o encharcamento do alimento. $O$ sucesso de alimentos fritos sob imersão depende da boa qualidade da fritura. A quantidade de gordura absorvida pelo alimento depende da velocidade de absorção que é influenciada pelo tempo de fritura, qualidade do óleo e do alimento. A umidade perdida pelo alimento é liberada sob forma de vapor durante a fritura.

\subsection{Métodos de avaliação da ocorrência de oxidação e perda da estabilidade}

Os métodos para acompanhamento de oxidação lipídica em alimentos podem ser divididos em aqueles que medem as alterações primárias e aqueles que medem as alterações secundárias, verificado por alterações químicas, físicas ou nas propriedades organolépticas do óleo (Shahidi, 1995).

As alterações primárias geralmente são medidas pela (a) diminuição do teor dos ácidos graxos insaturados, (b) utilização do oxigênio ou ganho de peso, (c) indice de peróxido e (d) valor de dienos conjugados. As alterações secundárias são monitoradas por quantificação de (a) carbonilas, determinada por cromatografia gasosa ou como dinitrofenil hidrozona, (b) equivalente em malonaldeído e outros aldeídos (teste de ácido tiobarbitúrico - TBA e de p-anisidina), (c) hidrocarbonetos (conteúdo de pentano ou etano) e (d) produtos fluorescentes (conteúdo de 1-amino-3-iminopropano).

É recomendado que se use uma combinação de métodos para verificação das alterações primárias e secundárias do óleo (Shahidi, 1995).

Na oxidação de óleos e gorduras, a taxa inicial de formação de hidroperóxidos excede sua taxa de decomposição, mas isso é revertido nos estágios posteriores. $\mathbf{O}$ método clássico para quantificação de hidroperóxidos é a determinação do índice de peróxido (Shahidi, 1995). No entanto, os hidroperóxidos são produtos intermediários na formação de carbonilas e hidroxi-compostos. Um teste acelerado a 
$100^{\circ} \mathrm{C}$ mostrou que o índice de peróxido passa por um valor máximo e é muito sensível às variações de temperatura (Gray, 1978).

A oxidação de ácidos graxos polinsaturados é acompanhada do aumento da absortividade do lipídio na faixa do espectro ultravioleta. Lipídios contendo dienos ou polienos apresentam uma alteração na posição de suas duplas ligações durante a oxidação, resultado de isomeração e conjugação. Os dienos conjugados exibem uma intensa absorção em $234 \mathrm{~nm}$, da mesma forma que os trienos conjugados absorvem em $268 \mathrm{~nm}$. Os dienos conjugados e índice de peróxido são bem relacionados durante a oxidação de óleos marinhos (baleia e bacalhau) e vegetais (canola e soja) e o método de dienos conjugados pode ser utilizado como um índice de estabilidade de lipídios (Shahidi, 1995).

A Tabela 2 apresenta os comprimentos de onda em que outros compostos formados durante a oxidação lipídica apresentam máxima absorção. 
Tabela 2. Máxima absorção dos principais grupos cromóforos dos produtos da oxidação.

\begin{tabular}{lc}
\hline Composto & UV (máximo nm) \\
\hline Monoeno & 190 \\
Dieno & $220-230$ \\
Trieno & $265-270$ \\
Tetraeno & $310-320$ \\
Aldeído cetônico & $265-280$ \\
Aldeído cetônico $\alpha, \beta$ etilênico & $220-250$ \\
& $310-330$ \\
$\alpha$-dicetona & 280 \\
$\alpha$-cetoaldeído & 282 \\
$\beta$-dicetona & 274 \\
ácido $\alpha$-cetônico & 210 \\
\hline
\end{tabular}

Fonte: Rovellini et al. (1997)

O método de dienos conjugados é mais rápido que a determinação do índice de peróxido e muito simples, pois não depende de reações químicas ou desenvolvimento de coloração e requer uma pequena quantidade de amostra (Gray, 1978).

Os compostos polares são produtos formados durante o aquecimento de óleo e gorduras. Os compostos polares incluem substâncias como monoglicerideos, diglicerídeos, ácidos graxos livres que ocorrem em gorduras sem uso, assim como a transformação dos produtos polares formados durante a fritura dos alimentos através da quebra dos hidroperóxidos. A determinação dos compostos polares totais tem provado ser exata, simples e reprodutível, é um método padrão aprovado pela IUPAC (1987) e AOAC (1984). O limite máximo é de $27 \%$ para se descartar o óleo de fritura (White, 1991). 
Wessels (1983) testou várias metodologias para determinação do teor de compostos polares totais em óleos de fritura e concluiu que o método de separação em coluna cromatográfica usando sílica como adsorvente é um método rápido, fácil de ser realizado e que permite boa separação entre triglicerídeos não alterados e o material polar e ainda que, existe boa correlação entre o grau de deterioração do óleo e o teor de compostos polares totais determinado por este método.

A Tabela 3 enumera os índices comumente utilizados assim como os compostos de alteração mais relacionados a estes índices. Na maioria trata-se de índices clássicos de análises de óleos e gorduras e estão padronizados. 
Tabela 3. Métodos analíticos baseados em mudanças físicas e químicas.

\begin{tabular}{|c|c|c|}
\hline Indice analítico & Compostos relacionados & Metodologia \\
\hline Viscosidade & $\begin{array}{l}\text { Polímeros, aumento de } \\
\text { saturação }\end{array}$ & DGF C-IV 7 \\
\hline Cor & $\begin{array}{l}\text { Compostos carbonílicos } \alpha \text {, } \\
\beta- \\
\text { Insaturados }\end{array}$ & AOCS Cc 13 b-45 \\
\hline Espuma & Polímeros surfactantes & - \\
\hline Absorção ultravioleta & Dienos e trienos conjugados & DGF C-IV 6 \\
\hline Constante dielétrica & Compostos polares & - \\
\hline Avaliação organoléptica & $\begin{array}{l}\text { Compostos voláteis e/ou } \\
\text { oxidados }\end{array}$ & AOCS Cg 2-83 \\
\hline Ponto de fumaça & $\begin{array}{l}\text { Compostos voláteis; ácidos } \\
\text { graxos livres }\end{array}$ & AOCS Cc $9 a-48$ \\
\hline Índice de acidez & Ácidos graxos livres & AOCS Ca 5a-40 \\
\hline Indice de iodo & Duplas ligações & AOCS Tz Ic- 85 \\
\hline Índice de peróxidos & Peróxidos & AOCs Cd 8-53 \\
\hline Índice de anisidina & Aldeídos & AOCS Cd 8-53 \\
\hline Reações colorimétricas & Ácidos graxos oxidados & DGF C-IV 6e \\
\hline
\end{tabular}

Fonte: Dobarganes \& Pérez-Camino (1991). A tabela reporta-se às metodologias oficiais mais utilizadas, podendo-se encontrar outras metodologias padronizadas para as determinações; (-) não existe metodologia oficial (extraida de Lima e Gonçalves,1995).

Segundo Mori (1994), o controle de qualidade de óleos inclui determinações de ácidos graxos livres (AGL) e valor de índice de peróxido (IP) junto com os testes acelerados de estabilidade e de avaliação sensorial. No caso de frituras o índice de peróxido nem sempre consegue refletir o grau de deterioração por ser instável, à altas temperaturas. 
Varela et al. (1983) estudaram a vida útil de óleos de oliva, soja e girassol empregados em frituras sucessivas de batatas e pescado. Para avaliar o grau de deterioração do óleo em função do tempo de fritura mediram as alterações no índice de iodo, peróxidos, refração, viscosidade e ponto de fumaça. Não encontraram nenhuma correlação importante entre os índices para um mesmo óleo exceto entre o ponto de fumaça e viscosidade. Também não detectaram diferença significativa nas avaliações sensoriais realizadas por um painel de degustadores treinados que não distinguiram os alimentos procedentes de quaisquer das frituras.

Lima \& Gonçalves (1994) estudaram a qualidade do óleo de soja usado intermitentemente por duas semanas num periodo total de 44 horas para fritura de diversos alimentos. Os resultados mostraram aumento na viscosidade, cor e dienos e trienos conjugados e redução no índice de iodo, ponto de fumaça e relação entre ácidos graxos insaturados e saturados. Os índices de acidez e peróxido apresentaram aumento no início do processo e redução no final e os valores de polímeros, compostos polares totais e estabilidade oxidativa apresentaram-se com pouca alteração. Os índices adotados apresentaram as variações esperadas com exceção de polimeros e compostos polares totais, fato que foi atribuído à baixa temperatura utilizada no processo de fritura (aproximadamente $150^{\circ} \mathrm{C}$ ). Os autores concluíram que estes índices não poderiam ser utilizados como único parâmetro legal de descarte do óleo.

Lima e Gonçalvez (1995) analisaram os resultados obtidos por vários autores e concluíram que os óleos de fritura apresentaram aumento nos índices de acidez, viscosidade, absorção UV (dienos), refração, cor e compostos polares totais quando comparados com óleos não aquecidos.

Smith et al. (1986) estudaram as mudanças que ocorrem no óleo de soja parcialmente hidrogenado, em frituras comerciais provenientes de restaurantes. Coletaram 65 amostras de óleo novo e usado. Para os óleos novos as porcentagens de compostos polares totais, ácidos graxos livres e composição em ácidos graxos foram 
similares, e nos óleos já utilizados para fritura ocorreram diversas alterações. Altas correlações foram obtidas entre a constante dielétrica, compostos polares totais e porcentagem de ácidos graxos livres com o tempo de fritura. Observaram mudanças na composição em ácidos graxos de algumas amostras e concluíram que estas estavam relacionadas com as trocas de gorduras dos alimentos que foram fritos.

Ans et al. (1999) avaliaram a qualidade dos óleos de fritura utilizados em restaurantes, lanchonetes, bares e pastelarias da cidade de São José do Rio Preto - SP. Analisaram 60 amostras e observaram que 30\% delas apresentaram valores de compostos polares superiores ao limite estabelecido para descarte, de $25 \% ; 18,3 \%$ estavam acima do $1 \%$ permitido para ácidos graxos livres (\% em ácido oléico), e que $8,3 \%$ estavam superiores ao limite de $15 \mathrm{meq} / \mathrm{kg}$ para $\mathrm{o}$ índice de peróxido. Os autores enfatizaram a necessidade de haver um melhor controle e conscientização.

Jorge (1996) conduziu estudos de fritura doméstica contínua com batata tipo palito a uma temperatura de $175^{\circ} \mathrm{C}$, usando o óleo de girassol convencional (OG) e o óleo de girassol com alto teor de oléico (OGAO), ambos adicionados de dimetil polisiloxano (DMPS). Cada óleo foi testado por 6 horas e analisaram-se o teor de compostos polares. Neste período o OG apresentou 11,7\%, o OGDMPS, 10,4\%, o OGAO, 7,0\% enquanto que o OGAODMPS, 5,8\% de compostos polares, concluindo que a eficiência do DMPS na prevenção da formação dos polares foi baixa neste tipo de fritura.

Moretti (1997) trabalhou com filézinhos de frango empanados pré-fritos e fritos, e verificou que a qualidade das gorduras de soja parcialmente hidrogenadas especificamente para o trabalho na pré-fritura contínua, foi muito similar às gorduras de algodão e soja do mercado. Na utilização intermitente das gorduras em pré-fritura, a gordura de algodão mostrou um desempenho apenas ligeiramente superior ao das gorduras de soja, ficando comprovado que é possível a utilização de gordura de soja parcialmente hidrogenada em substituição às de algodão, na pré-fritura de produtos 
empanados. A gordura de soja comercial empregada em quatro processos de pré-fritura em filézinhos de frango apresentou aumento dos índices de peróxido (de 1,27 a 3,73) e de ácidos graxos livres $(0,070$ a $0,101 \%$ oléico) .

\subsection{Aspectos nutricionais}

Óleos e gorduras correspondem ao componente da dieta mais calórico, portanto, os alimentos fritos tornam-se uma boa fonte de energia, sendo benéficos ao organismo, contudo em quantidades além das necessárias levam a um aumento do peso corpóreo, o que é indesejável (Berger, 1984).

Bognar (1998) comparou os métodos comuns de fritura com outros métodos como fervura, cocção no vapor e cozimento em relação ao valor nutricional de fritura de vegetais, carne à milanesa, aves e peixe. Depois da fritura, os alimentos retiveram quase sua totalidade em proteina, carboidrato e minerais, enquanto a fervura $\mathrm{e}$ a cocção no vapor reduziram de 25 a $50 \%$ a quantidade de minerais. Na maioria dos casos da fritura, incluindo a de imersão também reteve mais as vitaminas $B_{1}, B_{2}, B_{6}$ e $C$, na fervura, cocção no vapor e cozimento.

Óleos e gorduras aquecidos por longos períodos, sob temperatura extremamente altas, com quantidades elevadas de compostos polares (maiores que $50 \%$ ), administrados a animais provocaram severas irritações do trato gastro intestinal, diarréia, redução no crescimento e em alguns casos, até a morte (Billek, 1985).

Óleos aquecidos sob condições normais de fritura doméstica ou comercial $\left(180^{\circ} \mathrm{C}\right)$, com teor de compostos polares entre $10-20 \%$, com o tempo de fritura não superior a 96 horas administrados a animais, não se apresentaram prejudiciais (Billek, 1985). 


\subsection{Limites para utilização de óleos de fritura}

Dois simpósios de óleos e gorduras realizados pela "German Society for Fat Research" (DGF), sobre gorduras de fritura, resultaram em recomendações para controlar a qualidade de óleos e gorduras comestíveis (DGF, 1973 e 1979). Estas recomendações foram estabelecidas depois de informados sobre uma grande quantidade de casos de evidências de distúrbios gastrointestinais.

De acordo com as recomendações de 1973, as gorduras de fritura usadas são consideradas deterioradas se apresentarem: a) odor e sabor inaceitáveis; b) ponto de fumaça abaixo de $170^{\circ} \mathrm{C}$; c) concentração de ácidos graxos oxidados insolúveis em éter de petróleo de $0,75 \%$ ou mais; d) teor de ácidos graxos oxidados insolúveis em éter de petróleo maior que 1\% (Fritsch, 1981).

Depois do simpósio de 1979 , a DGF propôs que o método de cromatografia em coluna de sílica para determinação dos compostos polares fosse um bom complemento das avaliações organolépticas.

O método para esta determinação foi adaptado pela DGF (1979), IUPAC (1987) e AOAC (1984). As recomendações da DGF permitem um máximo de $27 \%$ de compostos polares que se aplicam a alimentos. Em 1979, foi considerado que a presença de $27 \%$ de compostos polares totais correspondia a $0,7 \%$ de ácidos graxos oxidados insolúveis em éter de petróleo. A determinação de compostos polares (IUPAC, 1987) é usado em substituição aos ácidos graxos insolúveis em éter de petróleo (Firestone et al., 1991).

Em 1989 a Espanha especificou que os óleos e gorduras não devem ter compostos estranhos, devem ser organolepticamente aceitáveis e devem conter menos de $25 \%$ de compostos polares totais, determinados pelo método 2507 da IUPAC (Firestone et al., 1991). 
As legislações de vários países seguem, com alguma alterações, os mesmos princípios propostos pela DGF. A Austrália, Bélgica, Japão e Finlândia adotam o valor máximo para o índice de acidez de $2,5 \%$, na Holanda este valor é de $4,5 \%$ e nos Estados Unidos é de 1\%. Na França e Bélgica não se permite a utilização de óleos com mais de 2\% de ácido linolênico para frituras (Firestone, et al., 1991).

\subsection{Análise sensorial}

A análise sensorial é usada para provocar, medir, analisar e interpretar as reações produzidas pelas características dos alimentos e materiais, como elas são percebidas pelos orgãos da visão, olfato, gosto, tato e audição (Amerine et al., 1965).

Depois de 1970, definiu-se qualidade sensorial de um alimento não como uma característica própria do alimento, mas sim como o resultado da interação entre o alimento e o homem. Reconhece-se que qualidade sensorial é função tanto dos estímulos procedentes dos alimentos como também das condições fisiológicas, psicológicas e sociológicas do indivíduo ou grupo que avalia o alimento (Dutcosky,1996).

Amerine et al. (1965) definiram qualidade sensorial como uma resposta individual, que varia de pessoa para pessoa, em função das diferenças em experiência, expectativa, grupo étnico, preferências, etc.

Segundo Dana (1992), a evolução sensorial dos alimentos e a avaliação da qualidade dos alimentos por um painel de provadores é essencial na maioria dos experimentos sobre alimentos, e que responde a importantes questões sobre sabor, odor, aspecto e textura dos alimentos. 
A avaliação sensorial é o único método para avaliar a qualidade e estabilidade do óleo, porque nenhum instrumento ou método químico foi desenvolvido no lugar dos nossos sentidos (Warner, 1995).

Dentre vários testes sensoriais, há o teste de aceitabilidade que pode ser medida por preferência ou gosto por um item específico do alimento (Amerine et al., 1965). Nesta forma mais simples, a aceitabilidade é concluída por escala de avaliação, são necessários de 25 a 50 provadores, não treinados. A escala de avaliação de atitude em relação ao alimento pode ser usada para medir a aceitação de produtos alimentícios por uma população. A escala não é aplicável para avaliação de características específicas, é uma medida de atitude geral em relação ao produto alimentício. Neste teste são apresentadas nove categorias sucessivas de avaliação e as amostras são apresentadas seqüencialmente em ordem balanceada e o provador é solicitado a decidir qual das afirmações na escala representa melhor sua atitude. As avaliações da escala são convertidas em valores numéricos, para facilitar a análise estatística dos dados (Mori et al., 1992). 


\section{MATERIAL E MÉTODOS}

O experimento foi realizado no restaurante universitário da Escola Superior de Agricultura "Luiz de Queiroz" da Universidade de São Paulo (ESALQ USP). De segunda a sexta-feira foram preparadas aproximadamente 850 refeiçð̃es diárias entre $o$ almoço e jantar. $O$ óleo selecionado para o estudo foi o de soja, obtidos de uma indústria nacional, em latas de $900 \mathrm{ml}$. A título de comparação, o último ensaio (frango e carne) foi conduzido paralelamente com outra marca de óleo de soja, também de uma indústria nacional.

A fritura foi realizada com óleo de soja refinado com temperatura inicial de $170^{\circ} \mathrm{C}$ e $180^{\circ} \mathrm{C}$ por 30 horas, ou até que alguma propriedade fisica ou organoléptica fosse afetada. As condições da fritura e temperatura foram as mesmas usadas em todo o estudo.

Os ensaios foram conduzidos em fritadeira elétrica de aço inoxidável, capacidade de 60 litros, divididos em dois compartimentos com cestos de aço inoxidável, marca Brasinox, modelo FTEMM 220XX3, com resistência imersa no óleo. 


\subsection{Procedimento}

O cardápio do restaurante universitário foi reformulado para se adaptar ao estudo. Para acompanhar as frituras elaborou-se uma planilha para anotação dos dados, conforme a categoria do alimento (APÊNDICE 1).

Os óleos empregados na fritura foram utilizados separadamente conforme as três categorias dos alimentos que compuseram o cardápio: fritura de alimentos de origem vegetal, de peixe, e de frango e carne.

Foram sempre necessários 10 minutos de aquecimento inicial do óleo para atingir a temperatura de $170^{\circ} \mathrm{C}$ a $180^{\circ} \mathrm{C}$. Com a adição do alimento a mesma baixava para $140^{\circ} \mathrm{C}$ e $150^{\circ} \mathrm{C}$ e no final de cada porcionamento, a mesma atingia, entre $160^{\circ} \mathrm{C}$ e $170^{\circ} \mathrm{C}$. Além do termostato da fritadeira a pesquisa foi monitorada com o auxílio de um termômetro. Durante a fritura, o cesto da fritadeira era agitado periodicamente, estabelecendo condições favoráveis para homogeneização da temperatura e distribuição do alimento, evitando o superaquecimento do óleo.

A adição de óleo novo, foi feita quando necessária e no início de cada fritura, visando sempre manter o mesmo nível, o bom funcionamento do equipamento e garantindo uma boa apresentação e qualidade do alimento servido.

Todos os alimentos foram submetidos ao pré-preparo, conforme a natureza do alimento e do tipo de preparação, que incluiu: limpar, descascar, fatiar, picar, temperar.

No total das frituras, foram utilizadas 275 latas de $900 \mathrm{ml}$ que correspondem a 248 litros de óleo soja refinado para fritar $1.453 \mathrm{~kg}$ de alimentos, a saber: $808 \mathrm{~kg}$ de frango (coxa e sobre-coxa), $12 \mathrm{~kg}$ de carne bovina (bife), $260 \mathrm{~kg}$ de pescado (filé de merluza) e $373 \mathrm{~kg}$ de diferentes vegetais crus, como batata, couve-flor e 
abobrinha, além de mandioca cozida. As Tabelas 4, 5 e 6 apresentam o programa de utilização e a quantidade de alimentos empregados em cada estudo.

\subsubsection{Fritura de vegetais}

A pesquisa com vegetais compreendeu 09 frituras, sendo que, cada uma delas foi executada em dia diferente, conforme o cardápio do restaurante.

Foram utilizadas 112 latas de $900 \mathrm{ml}$ que correspondem a 101 litros de óleo de soja para fritar $373 \mathrm{~kg}$ de alimentos: $16 \mathrm{~kg}$ mandioca cozida $(4,3 \%), 60 \mathrm{~kg}$ de couve-flor à doré (16\%), $48 \mathrm{~kg}$ de abobrinha à doré (13\%) e $249 \mathrm{~kg}$ de batata inglesa com corte tipo "chips" $(66,7 \%)$.

A fritura 01 foi iniciada nos dois compartimentos da fritadeira, comportando 54 litros de óleo. Ao final da fritura 02 , o óleo restante foi acondicionado em apenas um dos compartimentos para finalizar a fritura do dia, e o estudo continuou em apenas um compartimento até o final desta pesquisa. 
Tabela 4. Programa de utilização do óleo de soja e os alimentos empregados na fritura de vegetais.

\begin{tabular}{cclccc}
\hline $\begin{array}{c}\text { Fritura } \\
\mathrm{n}^{\mathbf{0}}\end{array}$ & $\begin{array}{c}\text { Reposição } \\
\text { latas/litros }\end{array}$ & \multicolumn{1}{c}{$\begin{array}{c}\text { Alimentos } \\
\text { fritos }\end{array}$} & $\begin{array}{c}\text { Quantidade } \\
(\mathrm{kg})\end{array}$ & T.F & T.A \\
\hline 01 & $60 / 54$ & Mandioca cozida & 16 & $45 \mathrm{~min}$ & $45 \mathrm{~min}$ \\
02 & - & Couve flor à doré & 60 & $4 \mathrm{~h} 40 \mathrm{~min}$ & \\
& - & Abobrinha à doré & 16 & $1 \mathrm{~h} 10 \mathrm{~min}$ & $6 \mathrm{~h} 35 \mathrm{~min}$ \\
03 & $4 / 3,6$ & Batata chips & 55 & $4 \mathrm{~h} 20 \mathrm{~min}$ & $10 \mathrm{~h} 55 \mathrm{~min}$ \\
04 & $13 / 11,7$ & Batata chips & 52 & $4 \mathrm{~h} 30 \mathrm{~min}$ & $15 \mathrm{~h} 25 \mathrm{~min}$ \\
05 & $9 / 8,1$ & Batata chips & 50 & $3 \mathrm{~h} 55 \mathrm{~min}$ & $19 \mathrm{~h} 20 \mathrm{~min}$ \\
06 & - & Abobrinha à doré & 16 & $2 \mathrm{~h} 05 \mathrm{~min}$ & $21 \mathrm{~h} 25 \mathrm{~min}$ \\
07 & $10 / 8,1$ & Batata chips & 46 & $3 \mathrm{~h} 50 \mathrm{~min}$ & $25 \mathrm{~h} 15 \mathrm{~min}$ \\
08 & $8 / 7,2$ & Batata chips & 46 & $4 \mathrm{~h} 20 \mathrm{~min}$ & $29 \mathrm{~h} 35 \mathrm{~min}$ \\
09 & $8 / 7,2$ & Abobrinha à doré & 16 & $1 \mathrm{hora}$ & $30 \mathrm{~h} 35 \mathrm{~min}$ \\
\hline
\end{tabular}

TF: tempo de utilização do óleo em cada fritura

TA: tempo acumulado de utilização do óleo de fritura

\subsubsection{Fritura de peixe}

A pesquisa compreendeu de 09 frituras, executada em dia diferente. Foram utilizadas 97 latas de $900 \mathrm{ml}$ que correspondem a 87,3 litros de óleo de soja refinado para fritar $260 \mathrm{~kg}$ de peixe (filé de merluza) enfarinhados. A previsão de consumo, em média, foi de 150 gramas per capita, e foram utilizadas aproximadamente 20 gramas de farinha de trigo por porção, num total de $35 \mathrm{~kg}$ de farinha de trigo

O primeiro dia da pesquisa, que correspondeu à fritura 01 foi realizada nos dois compartimentos da fritadeira, constando de 54 latas de óleo, que fritaram em 2 h05min, $54 \mathrm{~kg}$ de filé de merluza. Da fritura $02 \mathrm{em}$ diante, utilizou-se apenas um compartimento da fritadeira. 
Tabela 5. Programa de utilização do óleo de soja na fritura de peixe.

\begin{tabular}{cccclc}
\hline Amostra & $\begin{array}{c}\text { Reposição } \\
\text { Latas/litros }\end{array}$ & $\begin{array}{c}\text { Quantidade } \\
\text { peixe (Kg) }\end{array}$ & $\begin{array}{c}\text { Quantidade } \\
\text { de trigo (kg) }\end{array}$ & T.F & T.A \\
\hline 01 & $60 / 54$ & 54 & 7,2 & $2 \mathrm{~h} 05 \mathrm{~min}$ & $2 \mathrm{~h} 50 \mathrm{~min}$ \\
02 & $4 / 3,6$ & 7,5 & 1 & $40 \mathrm{~min}$ & $2 \mathrm{~h} 45 \mathrm{~min}$ \\
03 & $3 / 2,7$ & 60 & 8 & $3 \mathrm{~h} 45 \mathrm{~min}$ & $6 \mathrm{~h} 30 \mathrm{~min}$ \\
04 & $5 / 4,5$ & 7,5 & 1 & $45 \mathrm{~min}$ & $7 \mathrm{~h} 15 \mathrm{~min}$ \\
05 & $7 / 6,3$ & 54 & 7,2 & $3 \mathrm{~h} 15 \mathrm{~min}$ & $10 \mathrm{~h} 30 \mathrm{~min}$ \\
06 & $7 / 6,3$ & 9 & 1,2 & $1 \mathrm{hora}$ & $11 \mathrm{~h} 30 \mathrm{~min}$ \\
07 & & 10,5 & 1,4 & $1 \mathrm{hora}$ & $12 \mathrm{~h} 30 \mathrm{~min}$ \\
08 & $3 / 2,7$ & 50 & 6,6 & $3 \mathrm{~h} 50 \mathrm{~min}$ & $16 \mathrm{~h} 20 \mathrm{~min}$ \\
09 & $8 / 7,2$ & 7,5 & 1 & $30 \mathrm{~min}$ & $16 \mathrm{~h} 50 \mathrm{~min}$ \\
\hline
\end{tabular}

T.F: tempo de utilização do óleo para fritura

T.A: tempo acumulado da utilização do óleo de fritura

\subsubsection{Fritura de frango e carne}

À exceção dos estudos apresentados até agora, este estudo foi realizado com duas marcas de óleo de soja refinado, que serão identificadas como A e B. O óleo da marca A foi o mesmo utilizado nas frituras anteriores.

De cada marca de óleo, foram utilizadas 33 latas que correspondem a 30 litros de óleo, para fritar $410 \mathrm{~kg}$ de frango (coxa e sobrecoxa) que representaram, 98,5\% das preparações e $6 \mathrm{~kg}$ de carne bovina para bife, que representaram 1,6\%. A fritura 01 foi iniciada com apenas 26 latas de óleo, evitando que o mesmo transbordasse pelo fato do frango desprender parte da sua gordura no óleo de fritura. 
Tabela 6. Programa de utilização do óleo de soja e a quantidade de frango e carne empregados nas frituras com óleos A e B.

\begin{tabular}{cccccc}
\hline $\begin{array}{c}\text { Fritura } \\
\mathrm{n}^{\circ}\end{array}$ & $\begin{array}{c}\text { Reposição } \\
\text { latas/ litros }\end{array}$ & $\begin{array}{c}\text { Alimentos } \\
\text { fritos }\end{array}$ & $\begin{array}{c}\text { Quantidade } \\
(\mathrm{kg})\end{array}$ & T.F. & T.A. \\
\hline 01 & $26 / 23,4$ & Frango & 83 & $2 \mathrm{~h} 30 \mathrm{~min}$ & $2 \mathrm{~h} 30 \mathrm{~min}$ \\
02 & & Bife à milanesa & 6 & $25 \mathrm{~min}$ & $2 \mathrm{~h} 55 \mathrm{~min}$ \\
03 & $5 / 4,5$ & Frango & 11 & $40 \mathrm{~min}$ & $3 \mathrm{~h} 35 \mathrm{~min}$ \\
04 & & Frango & 11 & $40 \mathrm{~min}$ & $4 \mathrm{~h} 15 \mathrm{~min}$ \\
05 & & Frango & 83 & $3 \mathrm{~h} 25 \mathrm{~min}$ & $7 \mathrm{~h} 40 \mathrm{~min}$ \\
06 & & Frango & 53 & $2 \mathrm{~h} 05 \mathrm{~min}$ & $9 \mathrm{~h} 45 \mathrm{~min}$ \\
07 & & Frango & 18 & $1 \mathrm{~h}$ & $10 \mathrm{~h} 45 \mathrm{~min}$ \\
08 & & Frango & 17 & $40 \mathrm{~min}$ & $11 \mathrm{~h} 25 \mathrm{~min}$ \\
09 & $2 / 1,8$ & Frango & 83 & $3 \mathrm{~h} 35 \mathrm{~min}$ & $15 \mathrm{~h}$ \\
10 & & Frango & 45 & $2 \mathrm{~h}$ & $17 \mathrm{~h}$ \\
\hline
\end{tabular}

T.F: tempo de utilização do óleo para fritura

T.A: tempo acumulado da utilização do óleo de fritura

Após o término de cada fritura, o óleo foi filtrado e as amostras foram coletadas e acondicionadas em frascos de vidro âmbar com tampa e capacidade de 20 $\mathrm{ml}$, guardados em congelador para posterior análise. $\mathbf{O}$ óleo da fritadeira foi filtrado e acondicionado à temperatura ambiente, em galões de plásticos com tampa, não transparentes, armazenados, até a próxima reutilização.

Analisou-se o óleo através de análises fisicas (absortividade na faixa do espectro ultravioleta e cor Lovibond), químicas (índice de acidez e compostos polares totais). A análise sensorial foi feita nos alimentos fritos através do teste de aceitabilidade, por provadores não treinados. 


\subsection{Determinações analíticas}

\subsubsection{Determinações fisicas}

\subsubsection{Absortividade em $232 \mathrm{~nm}$ e em $270 \mathrm{~nm}$}

Foi determinada em espectrofotômetro Shimadzu, modelo UV 1203 conforme a NDG C-40 (SSOG, 1976). Foram feitas diluições de óleo em isoctano, de forma que a leitura de absorbância registrada estivesse entre 0,2 e 0,8 . Foram utilizados, balões volumétricos com $25 \mathrm{~mL}$ ou $50 \mathrm{~mL}$ de capacidade, dependendo do estado do óleo. Os resultados nos comprimentos de onda expressos em absortividade são dados pela fórmula:

$$
\begin{aligned}
& \text { Absortividade }=\frac{\mathrm{A}}{\mathrm{C} \times \mathrm{E}} \\
& \text { Onde: } \mathrm{A}=\text { absorbância registrada no comprimento de onda utilizado } \\
& \mathrm{C}=\text { concentração }\left(\mathrm{g} 100 \mathrm{~mL}^{-1}\right) \text { da solução amostrada } \\
& \mathrm{E}=\text { largura da cubeta utilizada }(\mathrm{cm}) .
\end{aligned}
$$

3.2.1.2 Espectro de absortividade na faixa do espectro ultravioleta - $220 \mathrm{~nm}$ a 320 nm

Realizado segundo IUPAC - 2.505 (1987), com as mesmas diluições em isoctano utilizadas na determinação da absortividade em $232 \mathrm{~nm}$ e $270 \mathrm{~nm}$. Foi utilizado o espectrofotômetro Shimadzu, modelo UV 1203 e a varredura foi realizada através do programa "Personal Spectroscopy" versão 1.1. As curvas fornecidas foram multiplicadas pelo fator de concentração para que os valores representassem os valores de absortividade em cada comprimento de onda e fossem comparáveis entre si. 


\subsubsection{Cor Lovibond}

Realizado segundo as normas AOCS - Cc 13b-45 (1990/1991). Este método determina a cor do óleo em cubeta de 5,25 centímetros, por comparação através da superposição de lentes amarelas (Y) e vermelhas (R).

\subsubsection{Determinações químicas}

\subsubsection{1 Índice de acidez}

Realizado segundo as normas da AOCS - Ca 5a-40 (1990/1991), com a dissolução de amostras de $5 \mathrm{~g}$ de óleo em álcool etílico a quente $\left(60-65^{\circ} \mathrm{C}\right)$ e titulação com hidróxido de sódio $0,1 \mathrm{~N}$. $\mathrm{O}$ volume gasto indicou a porcentagem de ácidos graxos livres (em ácido oléico) através da fórmula:

$$
\% \mathrm{AGL}=\frac{\mathrm{mL} \text { gastos } \times 28,2 \times \mathrm{N}}{\mathrm{P}}
$$

$$
\begin{aligned}
& \text { Onde: } \mathrm{N}=\text { normalidade da solução de sódio } \\
& \mathbf{P}=\text { massa da amostra (gramas) }
\end{aligned}
$$

\subsubsection{Compostos polares}

Aplicou-se o método proposto pela IUPAC - 2507 (1990/1991) com uma pequena modificação do conteúdo de solvente, sugerida por (Dobarganes et al., 1984). A mistura hexano:éter etílico na proproção de 90:10, foi usada ao invés de 87:13, para eluir a fração não polar, pois obtém-se uma melhor separação.

Preparação da coluna:

Vinte gramas de sílica gel foram pesados em um béquer e adicionados 50 ml de hexano:éter (90:10). A mistura foi transferida à coluna, cuja extremidade inferior 
era provida de lã de vidro. $O$ dissolvente em excesso era eliminado, sem que, em nenhum momento, deixasse de cobrir a sílica

Um grama de amostra foi pesado em um béquer de $25 \mathrm{ml}$. Com o auxílio de uma pipeta, adicionou-se 2 a $3 \mathrm{ml}$ da mistura hexano:éter $(90: 10)$ e, esta dissolução foi transferida à coluna.

Os componentes apolares foram eluídos com $150 \mathrm{ml}$ de hexano:éter (90:10), que foram recolhidos em um balão de $250 \mathrm{ml}$ previamente tarado. $O$ fluxo foi ajustado para que os $150 \mathrm{ml}$ passassem através da coluna em 60 a 70 minutos.

Após a eluição o dissolvente da fração foi eliminado utilizando um rotaevaporador a vácuo, com banho de água a $60^{\circ} \mathrm{C}$, e a fração foi determinada gravimetricamente.

Os compostos polares foram calculados pela diferença entre o peso da amostra adicionada à coluna e o da fração não polar eluída.

$$
\begin{aligned}
& \frac{m-m_{1-}}{m} \times 100 \\
& M=\text { massa em gramas da amostra adicionada à coluna. } \\
& M_{1}=\text { massa em gramas da fração não polar. }
\end{aligned}
$$

\subsection{Análise sensorial}

\subsubsection{Teste de aceitabilidade}

O teste de aceitabilidade foi realizado no restaurante universitário da ESALQ, no horário do almoço (11:00 -13:00 h). Para execução do teste foram necessários de 25 a 50 provadores, não treinados. Os comensais foram escolhidos aleatoriamente, preencheram uma ficha que era devolvida após a refeição (APÊNDICE 2). Participaram do 
teste provadores não treinados de ambos os sexos. Foi utilizada uma escala hedônica de 9 pontos ancorados em seus extremos nos termos gostei muitíssimo (9) e desgostei muitíssimo (1). Calculou-se o índice de aceitabilidade, onde a nota máxima (9) correspondeu a 100\% de aceitabilidade, e a média definiu o indice de aceitabilidade. Também foram feitos inquéritos sobre freqüência, forma e local de consumo do alimento.

\subsection{Análise estatística}

Para análise estatística, dos dados do teste de aceitabilidade, foi adotado um delineamento experimental, em blocos ao acaso. Os dados foram calculados utilizando o programa SANEST e avaliados através do teste $F$, da análise da variância e do teste Tukey (Pimentel-Gomes, 1990). 


\section{RESULTADOS E DISCUSSÃO}

O óleo inicial foi caracterizado pelas mesmas determinações analíticas que foram utilizadas no acompanhamento da qualidade do óleo de fritura (Tabela 7).

Tabela 7. Características iniciais do óleo de soja refinado.

\begin{tabular}{ll}
\hline & Resultados \\
\hline Indice de acidez (\% em ácido oléico) & 0,057 \\
Compostos polares (\%) & 6,0 \\
Cor Lovibond (Y/R) & $1,3 / 0,2$ \\
Absortividade em 232 nm & 4,187 \\
Absortividade em 270 nm & 1,473 \\
\hline
\end{tabular}

\subsection{Fritura de vegetais}

Uma das principais variáveis neste tipo de fritura é a velocidade de reposição de óleo fresco para compensar o óleo absorvido pelo alimento frito. 
Na Tabela 8 encontram-se os resultados das análises químicas e físicas do óleo de soja durante o estudo da fritura de vegetais que durou 30 horas e 35 minutos.

Tabela 8. Características do óleo de soja durante a fritura de vegetais.

\begin{tabular}{|c|c|c|c|c|c|c|c|}
\hline $\begin{array}{c}\text { Fritura } \\
\text { no }^{0}\end{array}$ & R.L. & $\begin{array}{c}\text { Tempo } \\
\text { acumulado }\end{array}$ & $\begin{array}{c}\text { Acidez } \\
\% \text { oléico }\end{array}$ & $\begin{array}{l}\text { Compostos } \\
\text { polares } \%\end{array}$ & $\begin{array}{c}\text { Cor Lovibond } \\
\text { Y / R }\end{array}$ & $A_{232 n m}$ & $\mathrm{~A}_{270 \mathrm{~nm}}$ \\
\hline 01 & 60 & $45 \mathrm{~min}$ & 0,1079 & 10,1 & $2,0 / 0,3$ & 4,741 & 1,585 \\
\hline 02 & & $6 \mathrm{~h} 35 \mathrm{~min}$ & 0,2598 & 19,3 & $11,0 / 1,3$ & 5,175 & 1,757 \\
\hline 03 & 4 & $10 \mathrm{~h} 55 \mathrm{~min}$ & 0,3491 & 21,6 & $13,0 / 2,0$ & 6,144 & 2,040 \\
\hline 04 & 13 & $15 \mathrm{~h} 25 \mathrm{~min}$ & 0,2832 & 20,1 & $11,0 / 1,7$ & 6,217 & 2,045 \\
\hline 05 & 9 & $19 \mathrm{~h} 20 \mathrm{~min}$ & 0,2693 & 19,1 & $9,9 / 1,7$ & 6,945 & 2,025 \\
\hline 06 & & $21 \mathrm{~h} 25 \mathrm{~min}$ & 0,2695 & 20,5 & $9,9 / 1,5$ & 9,497 & 2,276 \\
\hline 07 & 10 & $25 \mathrm{~h} 15 \mathrm{~min}$ & 0,3264 & 18,5 & $15,0 / 2,7$ & 9,516 & 2,302 \\
\hline 08 & 8 & $29 \mathrm{~h} 35 \mathrm{~min}$ & 0,3230 & 19,2 & $13,0 / 2,2$ & 10,134 & 2,515 \\
\hline 09 & 8 & $30 \mathrm{~h} 35 \mathrm{~min}$ & 0,2820 & 18,8 & $14,0 / 2,0$ & 9,123 & 2,293 \\
\hline
\end{tabular}

R.L: reposição em latas

\subsubsection{Acidez}

O índice de acidez, ao final do segundo dia do estudo, que correspondeu à fritura 02 , sofreu um significativo acréscimo, provavelmente pelo longo período de aquecimento. 
O aumento ou diminuição deste índice refletiu o tempo de fritura e a reposição com óleo novo. A Figura 2 apresenta a progressão da hidrólise do óleo nesta fritura.

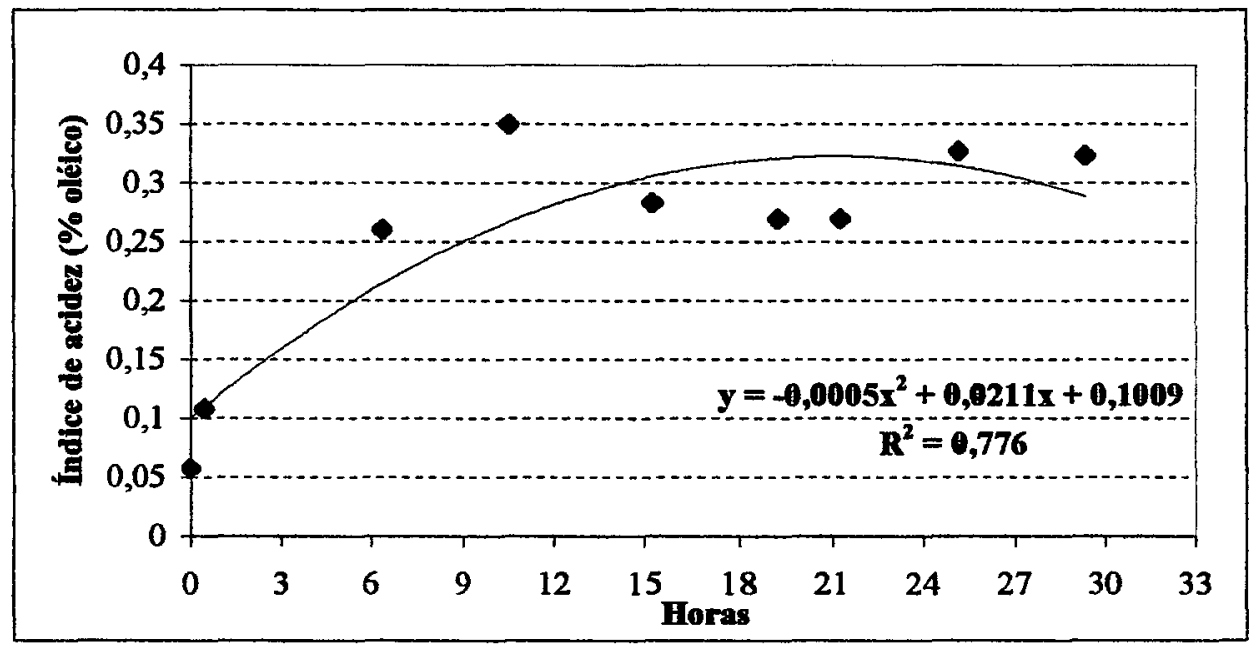

Figura 2 - Índice de acidez no óleo da fritura de vegetais.

O aumento da acidez indica o desenvolvimento de reações hidrolíticas com a produção de ácidos graxos livres que ocorre devido à presença de água e da alta temperatura, pois, quanto maior o percentual de água no alimento, mais rapidamente ela ocorre (Berger, 1984).

$O$ ato de fritar um produto alimentício como, por exemplo, a batata "in natura" que contém água intrínseca e extrínseca, oriunda do pré-preparo, exerce um efeito deteriorativo ainda maior sobre o óleo aquecido (Perkins et al., 1965). Neste estudo não atingiu 1\% para o índice de acidez, considerando os Estados Unidos, cuja legislação é a mais exigente quanto à qualidade do óleo de fritura, o valor máximo para índice de acidez de é 1\% (Firestone et al., 1991).

Pode-se observar que em $6 \mathrm{~h} 35 \mathrm{~min}$ ocorreu um acréscimo da acidez e na sequêencia, mesmo com a reposição de 4 latas de óleo o processo de hidrólise continuou. Após este periodo que correspondeu a fritura 04 , a adição de 13 latas, representando $43,3 \%$ de óleo fresco aquecido por 4 horas de fritura provocou uma regressão deste 
indice. A partir das $10 \mathrm{~h} 55 \mathrm{~min}$, a alta rotatividade de óleo novo deve ter colaborado para manter o incremento da acidez baixo.

\subsubsection{Compostos polares}

A determinação do teor dos compostos polares totais tem sido um dos melhores métodos para determinação do estado de alteração do óleo de fritura, segundo Pérez-Camino et al. (1988). Pode-se observar que a porcentagem de compostos polares totais elevou-se em apenas 45 minutos de fritura, demonstrando que o aquecimento mesmo em periodo curto é prejudicial para a qualidade do óleo.

No final das frituras 02 e 03 , este índice teve um acréscimo significativo, provavelmente pelo mesmo motivo relatado para o índice de acidez. Depois das 10h55min (fritura 04) de aquecimento, o óleo apresentou pequenas alterações provocadas pela adição de óleo novo, que correspondeu de $26,6 \%$ a $43,3 \%$ de rotatividade, reposições estas necessária para repor o óleo absorvido pelo alimento. Mesmo ao final das 30 horas de fritura o teor de compostos polares não alcançou o valor dos $20 \%$, considerado alto.

Cuesta \& Muniz (1998) verificaram que a alta reposição de óleo fresco, isto é, a frequente rotatividade de óleo novo, evitou que o nível de $25 \%$ de compostos polares seja alcançado, provavelmente pela absorção de parte desses compostos pelos alimentos e também pelo efeito de diluição. $O$ limite de compostos polares para descartar um óleo de fritura aceito pela regulamentação espanhola é de $25 \%$ (Firestone et al., 1991). No presente estudo o valor máximo manteve-se entre $18 \%$ a $22 \%$ por mais de 30 horas. A Figura 3 apresenta a evolução do teor dos compostos polares nesta fritura. 


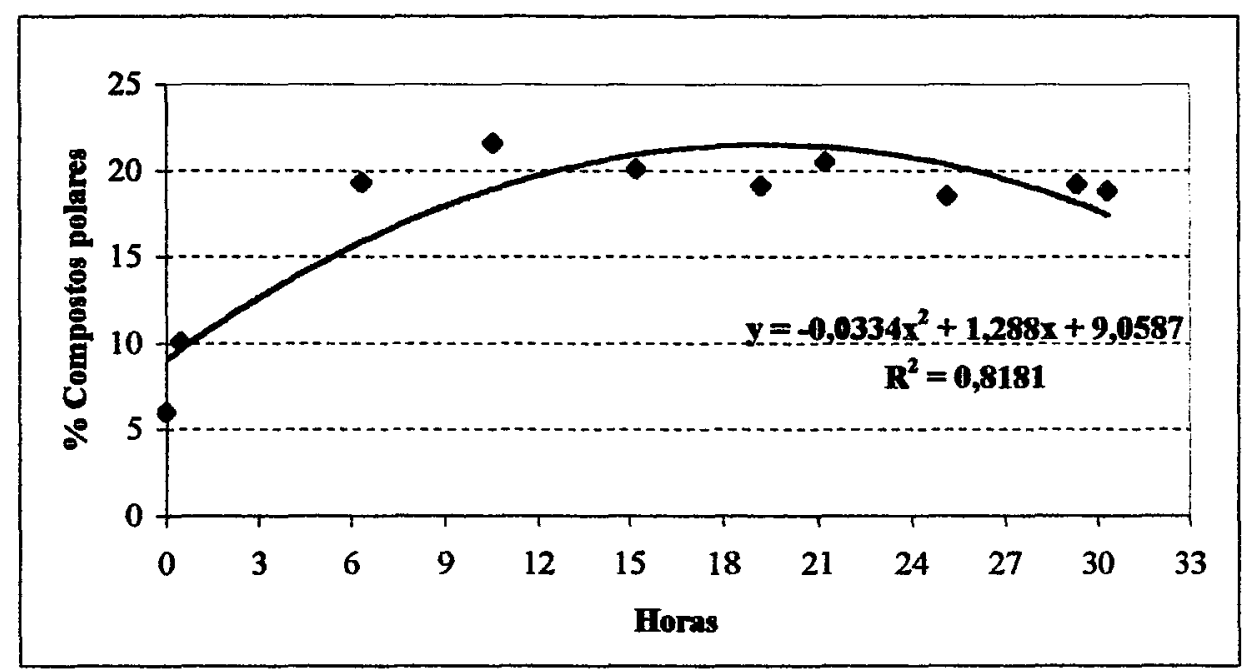

Figura 3- Teor de compostos polares no óleo da fritura de vegetais.

O comportamento do teor de compostos polares acompanhou o índice de acidez e refletiu a alta reposição de óleo ocorrida durante o processo de fritura. Stevenson et al. (1984), fritando batatas “chips” em fritadeira elétrica com reposição constante de óleo, demonstraram que a correlação entre ácidos graxos livres, compostos polares totais e tempo de fritura foi alta, e concluíram que a análise de ácidos graxos livres foi um parâmetro rápido e simples para controle da alteração no sistema analisado. A relação entre os índices alterou-se com a matéria-prima frita.

A Figura 4 apresenta a correlação entre índice de acidez (\% em ácido oléico) e o teor de compostos polares nesta fritura. 


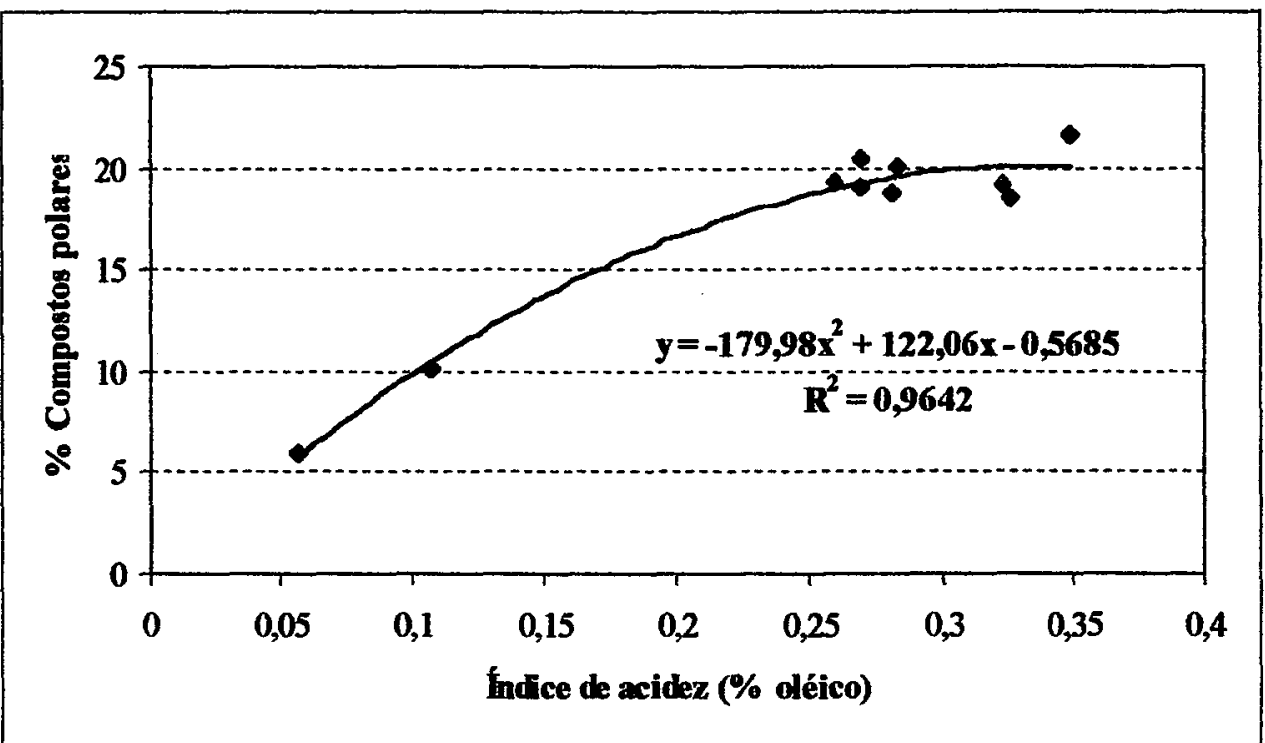

Figura 4 - Correlação entre o teor de compostos polares e o índice de acidez no óleo da fritura de vegetais.

O índice de acidez e compostos polares confirmaram a correlação existente neste tipo de fritura, conforme já verificado em outros estudos.

\subsubsection{Absortividade na faixa do ultravioleta}

Alguns produtos da oxidação apresentam valores máximos de absorção em determinado comprimento de onda do espectro. Compostos primários da oxidação apresentam valores máximos de absortividade na faixa entre $220 \mathrm{~nm}$ e $234 \mathrm{~nm}$. A partir de $265 \mathrm{~nm}$ são compostos secundários da oxidação (trienos, aldeídos, cetonas) que apresentam maior absorção (Shahidi, 1995). As informações podem ser encontrados na Tabela 2.

O acompanhamento dos espectros de absortividade das amostras do óleo forneceu uma boa indicação das alterações que ocorreram durante o processo oxidativo. A Figura 5 apresenta os espectros de absortividade do óleo ao final de cada período de fritura. 


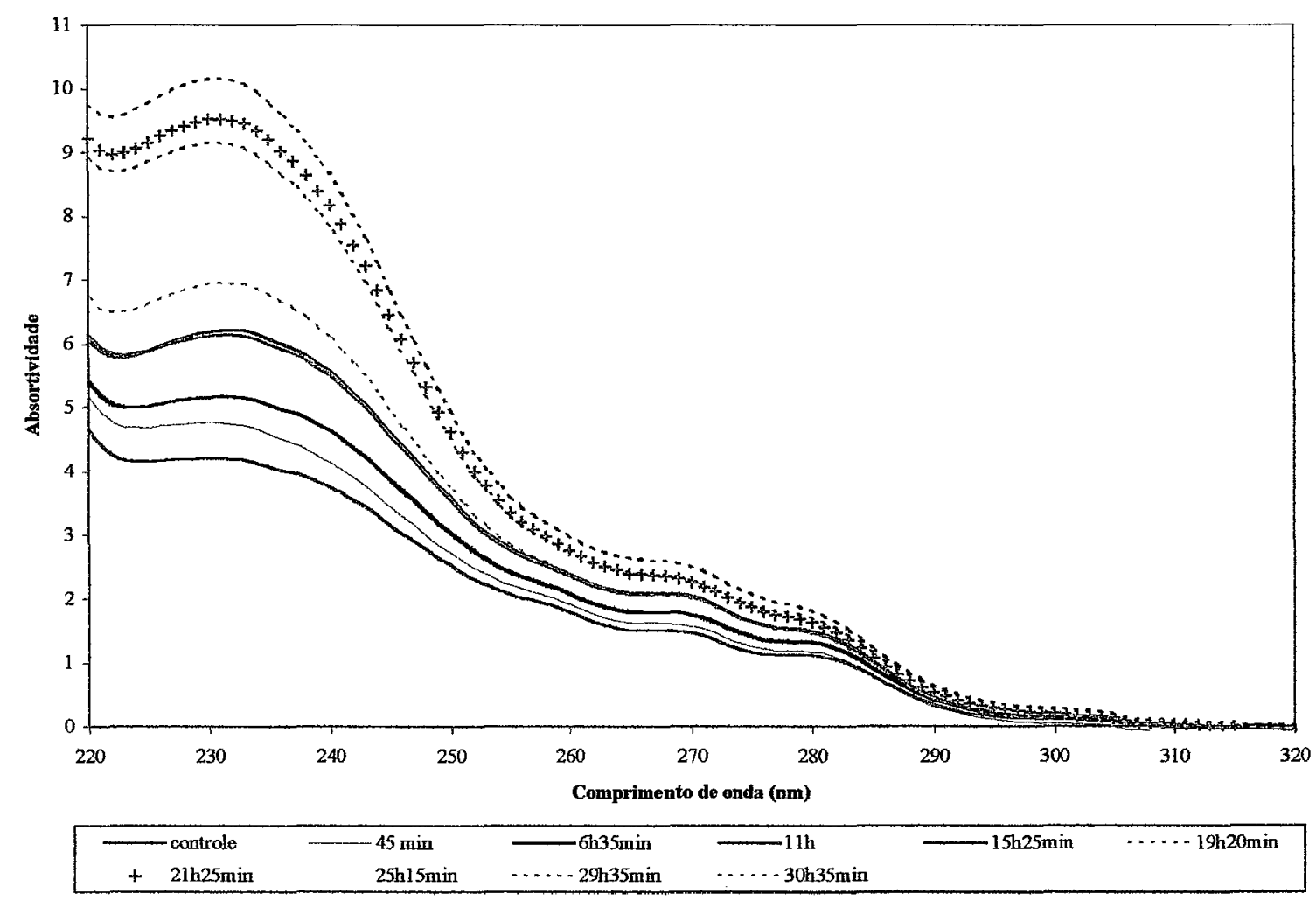

Figura 5 - Espectro de absortividade na faixa do UV no óleo da fritura de vegetais.

Os espectros de absortividade apresentados na Figura 5 indicam que $o$ aquecimento próximo de $170^{\circ} \mathrm{C}$ por $29 \mathrm{~h} 35 \mathrm{~min}$ promoveu aumento crescente nos valores de absortividade na faixa de $232 \mathrm{~nm}$ em função das horas e das reposições de óleo fresco, indicando que os dienos formados pelos peróxidos estão em acúmulo com o processo. Na fritura 06 que correspondeu a $21 \mathrm{~h} 25 \mathrm{~min}$ de aquecimento intermitente que não contou com a adição de óleo fresco observou-se um acréscimo maior, como pode ser verificado através da análise das curvas.

\subsubsection{Cor Lovibond}

A cor do óleo depende da qualidade do refino e dos alimentos que se fritam. Quando óleos muito insaturados como o de soja são aquecidos ocorre isomerização e migração de duplas ligações, levando à conjugação das mesmas. A conjugação de duplas ligações leva à absorção de quantidades maiores de luz azul, 
provocando um aumento de cores laranja e marrom no óleo. Portanto, a cor do óleo irá depender do teor inicial de duplas ligações e dos alimentos que se fritam (Lima \& Gonçalves, 1994).

Durante o processo de fritura o óleo tende a escurecer, por várias razões, dentre elas a absorção ou passagem dos pigmentos escuros dos alimentos para o óleo, do escurecimento do alimento devido às reações de Maillard, dentre outros. A Figura 6 apresenta a progressão das cores $\mathrm{Y}$ e $\mathrm{R}$ nesta fritura.

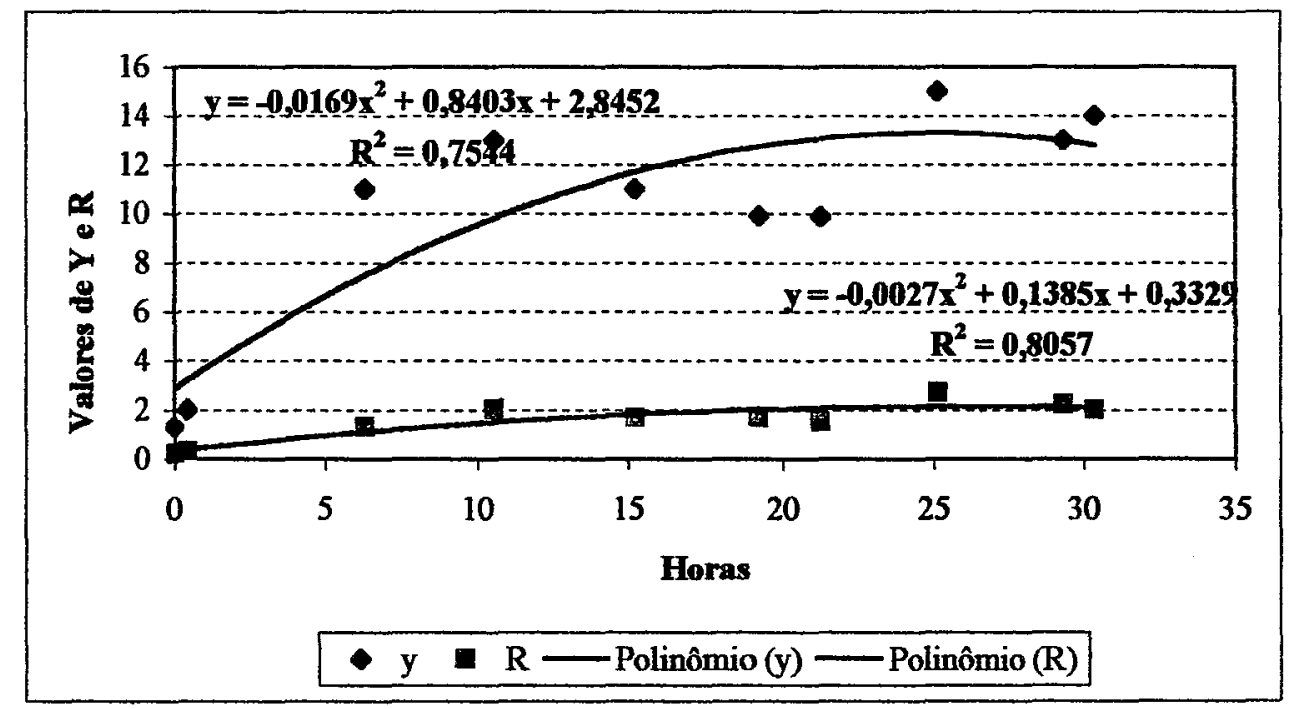

Figura 6 - Cor Lovibond no óleo da fritura de vegetais.

Graficamente a curvas refletem a oxidação do óleo através da acentuação da cor amarela e vermelha e perda da qualidade. Os valores de Y e R apresentaram uma boa correlação com o índice de acidez (\% em ácido oléico), conforme mostra a Figura 7. 


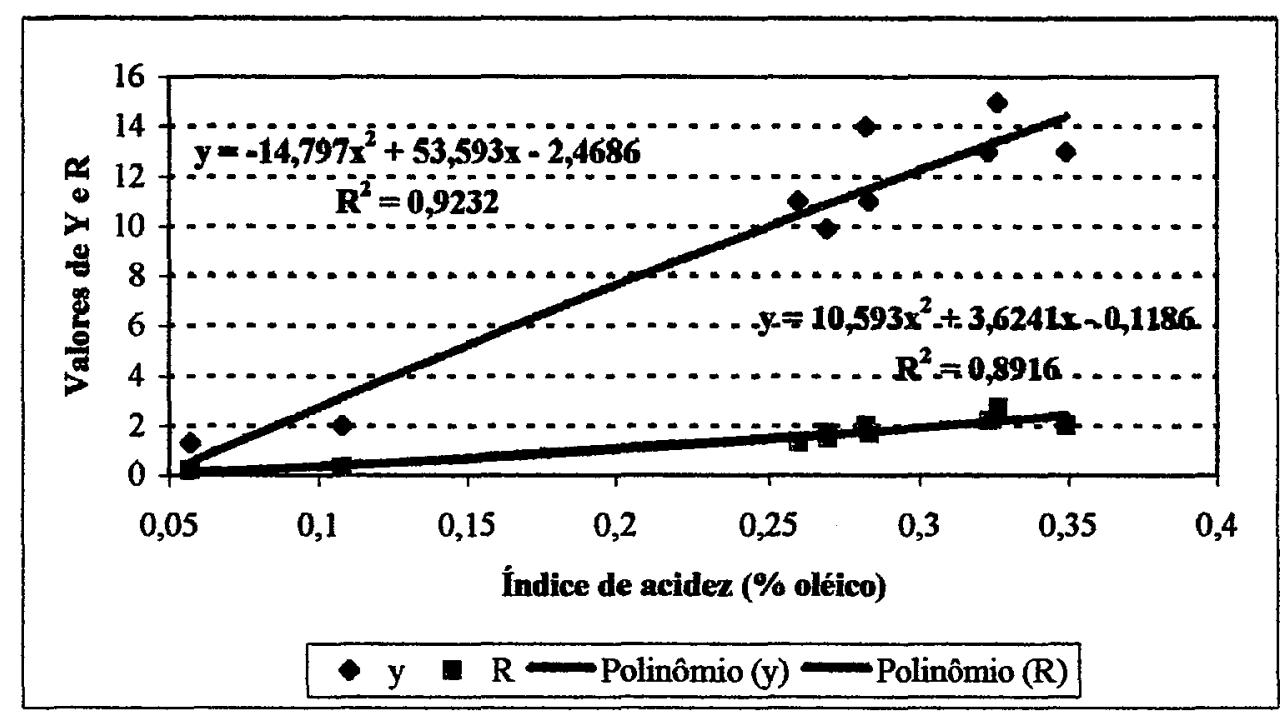

Figura 7 - Correlação entre índice de acidez e cor Lovibond no óleo da fritura de vegetais.

\subsubsection{Análise sensorial}

As características sensoriais determinam a aceitabilidade ou não de um produto. Os atributos sensoriais, tais como cor, odor, textura e o sabor entre outros, são fatores que influenciam a utilização em vários produtos, sendo que o sabor é a mais importante propriedade na determinação da aceitabilidade de um alimento (Moraes, 1993).

$O$ teste de aceitabilidade dos alimentos fritos de origem vegetal foi conduzido em 6 períodos e cada período correspondeu às seguintes horas acumuladas das frituras: 6h35min (fritura 02), 10h55min (fritura 03), 15h25min (fritura 04), $19 \mathrm{~h} 20 \mathrm{~min}$ (fritura 05), 25h15min (fritura 07), 29h35min (fritura 08). Como o valor de $\mathrm{F}$ foi significativo, realizou-se o teste Tukey. Os resultados estão apresentados na Tabela 9. 
Tabela 9. Médias das notas do teste de aceitabilidade da fritura de vegetais.

\begin{tabular}{ll}
\hline Período & Médias \\
\hline 1 (fritura 02) & $8,20 \mathrm{a}$ \\
2 (fritura 03) & $7,50 \mathrm{bc}$ \\
3 (fritura 04) & $7,69 \mathrm{abc}$ \\
4 (fritura 05) & $7,19 \mathrm{c}$ \\
5 (fritura 07) & $7,73 \mathrm{abc}$ \\
6 (fritura 08) & $7,96 \mathrm{ab}$ \\
\hline Valor F & 3,94 \\
Coeficiente de variação & $12,06 \%$ \\
\hline Médias seguidas por letras distintas diferem entre si em nível de 0,05 de significância.
\end{tabular}

A Figura 8 apresenta a média das notas dos provadores em relação às horas acumuladas que estão representadas por períodos dos alimentos fritos.

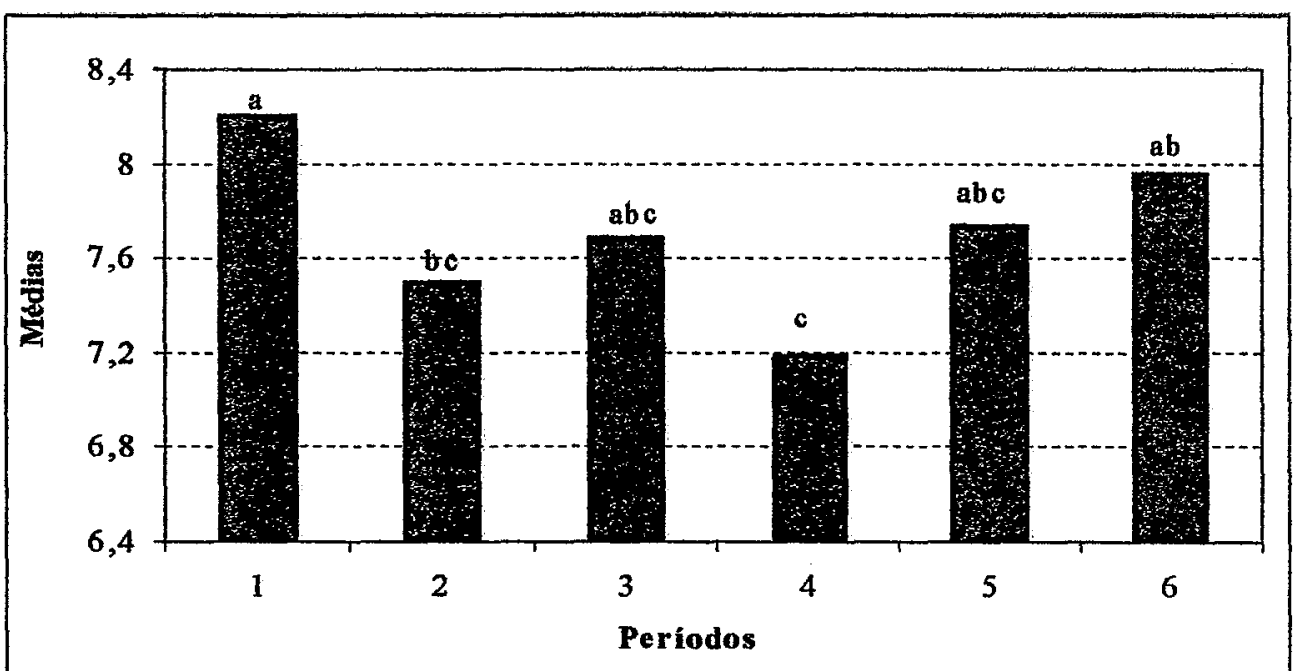

Figura 8 - Comportamento dos provadores em relação à aceitabilidade da fritura de vegetais.

Observa-se pela Tabela 9, que durante todo o periodo das frituras, as notas oferecidas pelos provadores estiveram dentro do intervalo de "gostei muito", a 
"gostei moderadamente" (APÊNDICE 2). A nota mais alta foi observada pelos provadores no $1 \%$ período. Entretanto, não foram observadas alterações aparentes nos vegetais submetidos às frituras dos demais periodos, quando comparadas com o primeiro período. Em todos os períodos, foram observados os atributos "seco" e "crocante" de textura, somente alguns provadores observaram os atributos "encharcada" e "oleosa", nos períodos 2, 3, e 4, e ainda assim, caracterizando-se como "um pouco encharcada" ou "um pouco oleosa". Podem-se caracterizar esses atributos, como os responsáveis pela ligeira diminuição das notas dos provadores.

Quanto ao sabor e aroma dos alimentos fritos, os provadores foram unânimes em observar os atributos "leve", "suave" e "característico de fritura" e "sem cheiro ou gosto de óleo de fritura". Interessante observar, que o atributo "ranço", o qual era esperado, não apareceu em nenhum período do experimento, mesmo nos últimos períodos de fritura, os quais não diferiram significativamente do primeiro período (Figura 8).

\subsection{Fritura de peixe.}

Este tipo de preparação do peixe também contribuiu para a degradação do óleo, as partículas da farinha de trigo desprenderam-se do peixe ficando acumuladas no interior da fritadeira, favorecendo o escurecimento do óleo e também do produto frito. Se a fritura é longa, as partículas de farinha de trigo são queimadas, carbonizando o óleo e conferindo sabores e aromas desagradáveis. Este tipo de preparação provoca maiores perdas de óleo pelo acúmulo de farinha de trigo queimada no interior da fritadeira.

Ao final das $16 \mathrm{~h} 50 \mathrm{~min}$ de fritura as características fisicas do óleo estavam alteradas, a cor apresentou-se intensa (marrom avermelhado), a textura espessa (possivelmente pela ação do amido presente na farinha de trigo), aparecimento de espuma e ainda um odor forte, mas, característico de peixe. Neste momento o óleo foi 
descartado pelas suas características fisicas e sensoriais, evitando uma depreciação do alimento frito, ou ainda, complicações para os comensais.

Na Tabela 10 encontram-se os resultados das análises químicas e físicas do óleo de soja durante o estudo da fritura de peixe.

Tabela 10. Características do óleo de soja durante a fritura de peixe.

\begin{tabular}{|c|c|c|c|c|c|c|c|}
\hline $\begin{array}{c}\text { Fritura } \\
n^{\circ}\end{array}$ & R.L. & $\begin{array}{c}\text { Tempo } \\
\text { acumulado }\end{array}$ & $\begin{array}{c}\text { Acidez } \\
\% \text { oléico }\end{array}$ & $\begin{array}{c}\text { Compostos } \\
\text { polares \% }\end{array}$ & $\begin{array}{c}\text { Cor Lovibond } \\
\text { Y / R }\end{array}$ & $A_{232 n m}$ & $\overline{\mathbf{A}_{270 \mathrm{~mm}}}$ \\
\hline 01 & 60 & $2 \mathrm{~h} 05 \mathrm{~min}$ & 0,1068 & 12,5 & $4,1 / 0,5$ & 4,811 & 1,731 \\
\hline 02 & 4 & $2 \mathrm{~h} 45 \mathrm{~min}$ & 0,1338 & 15,5 & $6,5 / 0,9$ & 5,511 & 1,855 \\
\hline 03 & 3 & $6 \mathrm{~h} 30 \mathrm{~min}$ & 0,2678 & 17,2 & $18,0 / 2,4$ & 5,626 & 1,955 \\
\hline 04 & 5 & Th15min & 0,2690 & 18,2 & - & 5,726 & 1,957 \\
\hline 05 & 7 & $10 \mathrm{~h} 30 \mathrm{~min}$ & 0,3771 & 19,3 & $36,0 / 3,8$ & 7,701 & 2,142 \\
\hline 06 & 7 & $11 \mathrm{~h} 30 \mathrm{~min}$ & 0,3235 & 13,3 & $32,0 / 3,6$ & 7,614 & 2,088 \\
\hline 07 & & $12 \mathrm{~h} 30 \mathrm{~min}$ & 0,3905 & 15,8 & $38,0 / 4,2$ & 9,219 & 2,307 \\
\hline 08 & 3 & $16 \mathrm{~h} 20 \mathrm{~min}$ & 0,5750 & - & $70,0 / 6,3$ & 8,745 & 2,215 \\
\hline 09 & 8 & $16 \mathrm{~h} 50 \mathrm{~min}$ & 0,4735 & 17,1 & - & 7,988 & 1,978 \\
\hline
\end{tabular}

(-) determinação não realizada

R.L: reposição em latas 


\subsubsection{Acidez}

Observou-se a ocorrência de reações hidrolíticas pelo aumento da acidez; com o aumento do tempo da fritura, maior foi a acidez. $\mathrm{O}$ comportamento da acidez foi semelhante ao da fritura de vegetais até $10 \mathrm{~h} 30 \mathrm{~min}$, atingindo em média $0,36 \%$.

Nos períodos de fritura igual ou inferior a 60 minutos que apresentaram reposição entre $23,3 \%$ a $26,6 \%$, houve redução neste índice, dentro da faixa de rotatividade de óleo fresco recomendada por Stevenson et al. (1984). A Figura 9 apresenta o comportamento do índice de acidez na fritura de peixe.

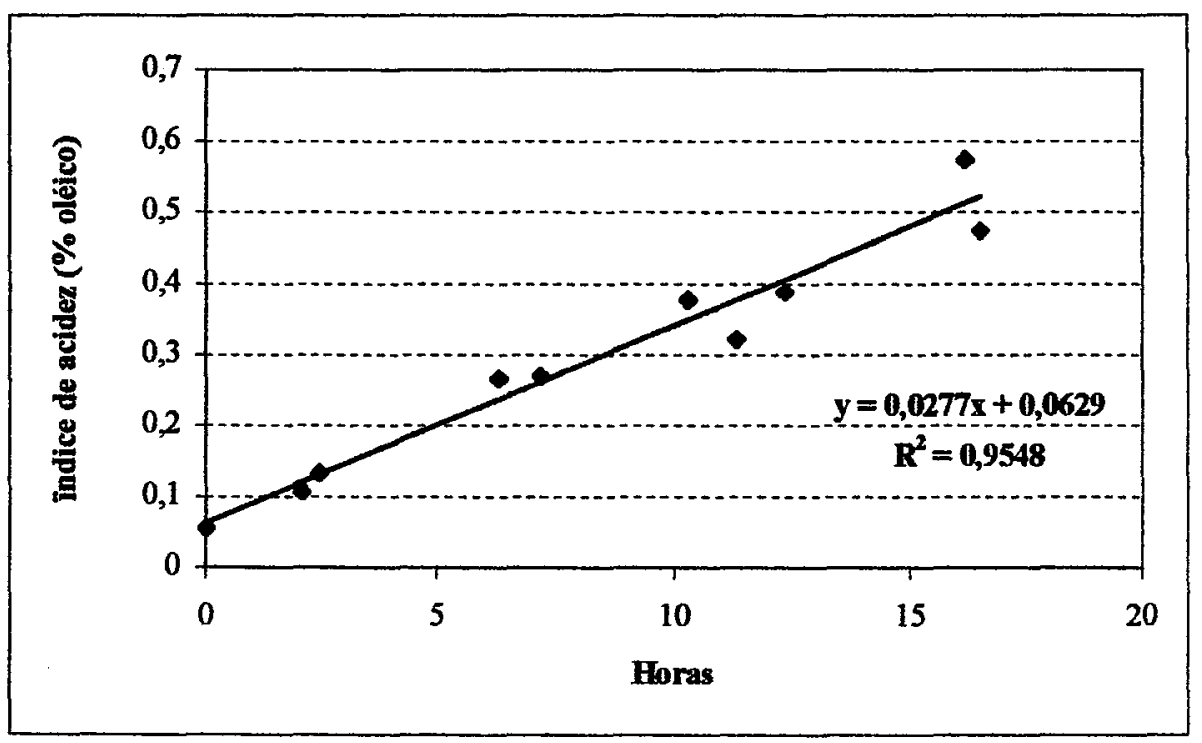

Figura 9 - Índice de acidez no óleo da fritura de peixe.

Observou-se nesta pesquisa que a maioria das frituras ocorreram em períodos curtos e isto também favorece o processo de degradação do óleo. Segundo Pérez-Camino et al. (1988), a acidez e o ponto de fumaça podem ser considerados como indices substitutos de determinações cromatográficas no controle da qualidade do óleo de fritura. 


\subsubsection{Compostos polares}

A complexa mistura de compostos de alteração que constituem a fração polar é originada da hidrólise do óleo envolvendo a quebra de ligações éster com formação de ácidos graxos, mono e diglicerídeos e degradações oxidativas e térmicas que ocorrem nos grupos insaturados dos triglicerídeos, modificando as propriedades nutricionais do óleo. Isto significa que os compostos polares diferem não apenas em sua polaridade e peso molecular, mas também em seu significado nutricional (Márquez-Ruiz et al., 1990).

As principais alterações neste tipo de processo de fritura são decorrentes da velocidade de reposição de óleo fresco para compensar as perdas dos produtos retidos no fundo da fritadeira e do óleo absorvido pelo alimento frito. A Figura 10 apresenta o teor dos compostos polares no óleo da fritura de peixe.

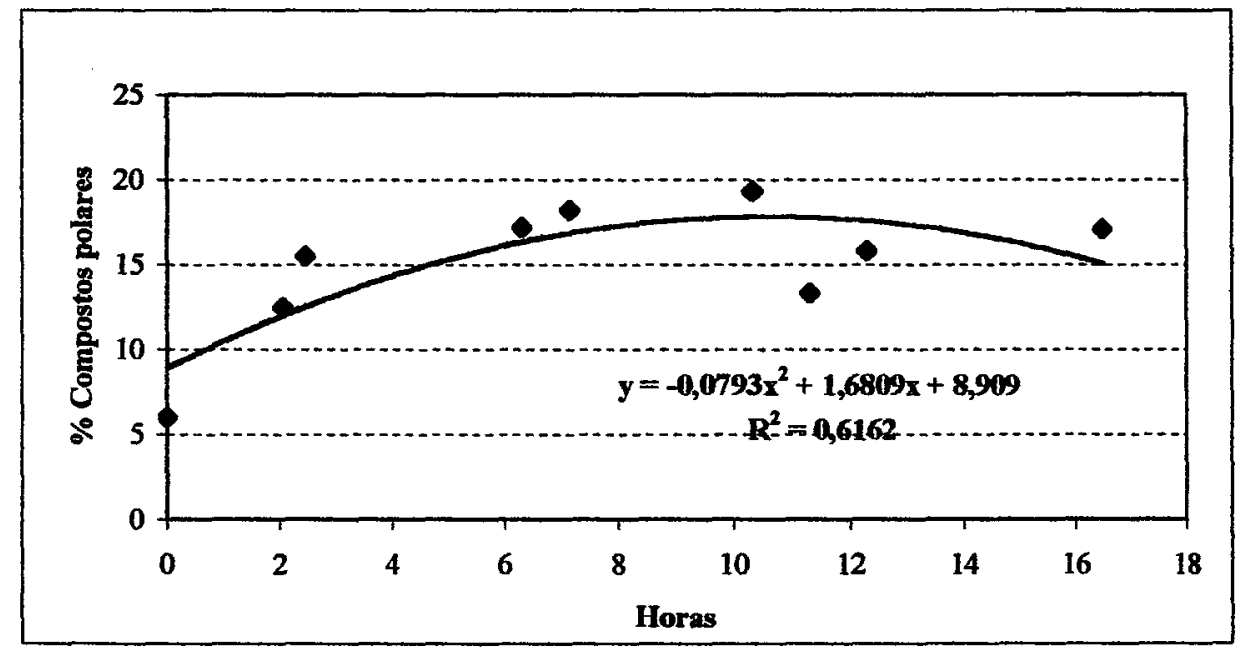

Figura 10- Teor dos compostos polares no óleo da fritura de peixe.

Observou-se um aumento crescente do teor de compostos polares até o período de 10h30min, o mesmo já encontrado no índice de acidez. Após este período, a adição de 7 latas, representando $23,3 \%$ de óleo fresco aquecido por 1 hora de fritura, provocou uma regressão deste índice. Na seqüência do estudo, a ausência de reposição, 
levou a uma ligeira elevação. As reposições freqüentes em períodos curtos retardam as alterações, isto é, evitam que os indices se elevem pela diluição.

A Figura 11 apresenta a correlação entre o índice de acidez (\% em ácido oléico) e o teor de compostos polares nesta fritura.

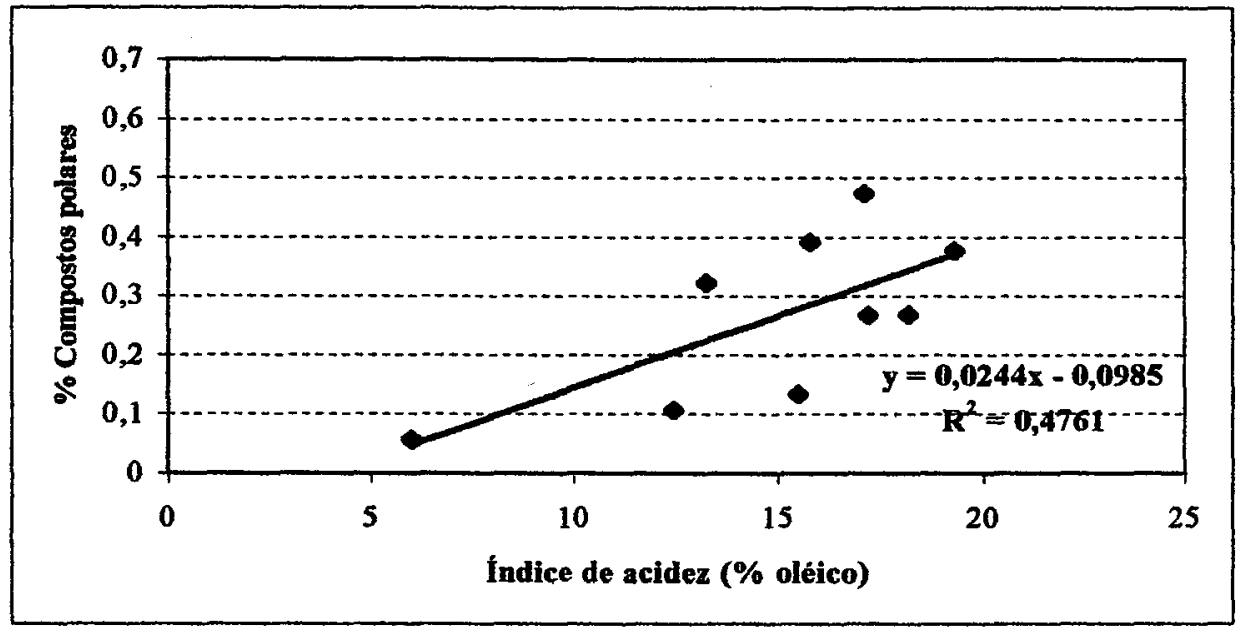

Figura 11 - Correlação entre o teor de compostos polares e o índice de acidez no óleo da fritura de peixe.

Observou-se que a mudança da matéria-prima, neste caso, fritura de peixe não levou uma boa correlação entre o índice de acidez e de compostos polares. Na fritura de vegetais com reposição de óleo constante, obteve-se uma boa correlação entre ácidos graxos livres, compostos polares totais e tempo de fritura.

\subsubsection{Absortividade na faixa do ultravioleta}

A determinação da absortividade em $232 \mathrm{~nm}$ reflete o estado de oxidação do óleo. A determinação da absortividade em $268 \mathrm{~nm}$ e a variação entre 262 e $274 \mathrm{~nm}$, ou entre 277 e $283 \mathrm{~nm}$, revela a presença de compostos secundários da oxidação e de trienos conjugados (IUPAC, 1987). 
Provavelmente as propriedades químicas do alimento tenham influência no comportamento da absortividade. A Figura 12 apresenta os espectros de absortividade dos óleos ao final de cada período da fritura de peixe.

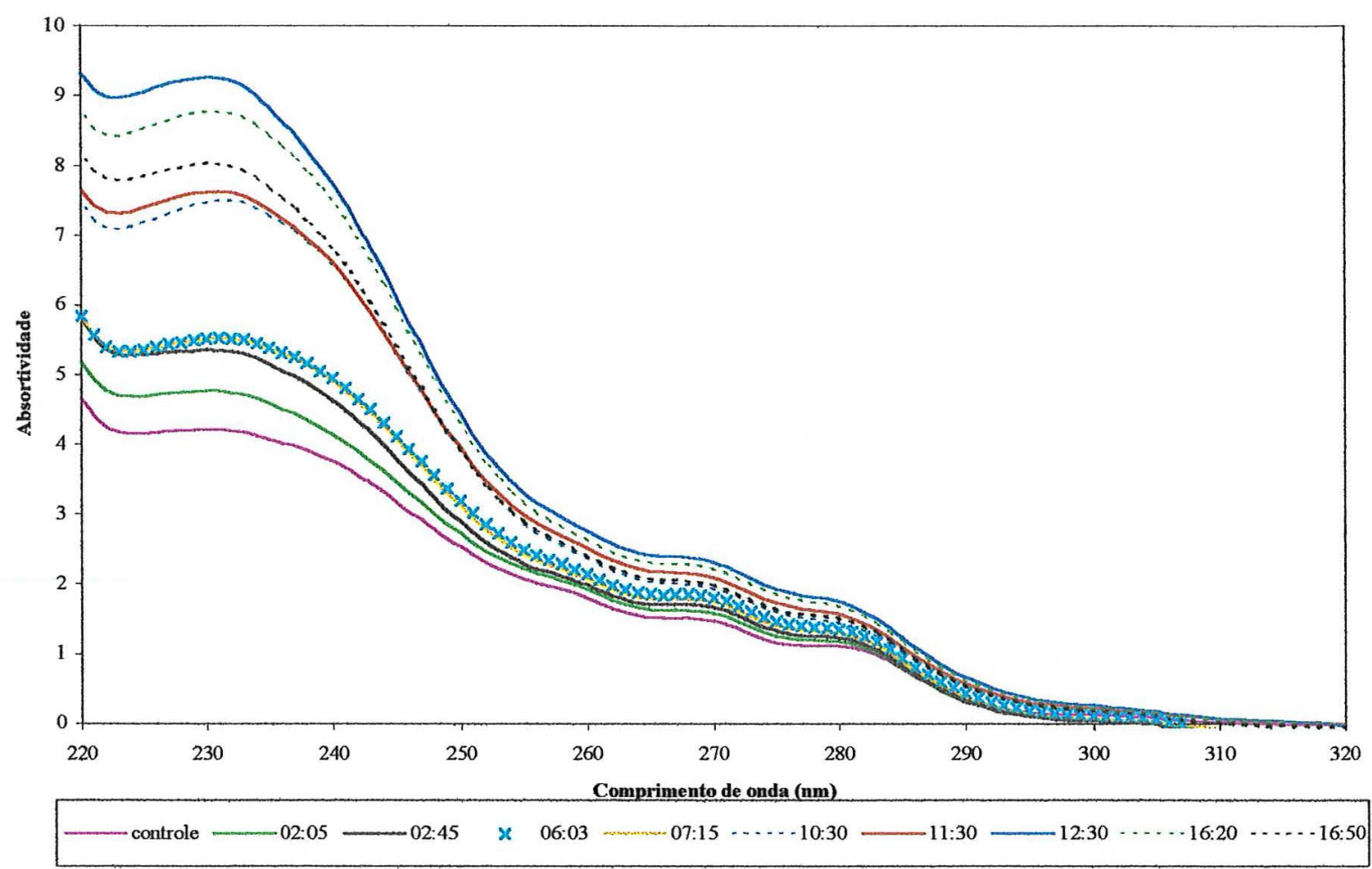

Figura 12 - Espectro de absortividade na faixa do UV no óleo da fritura de peixe.

Os espectros de absortividade apresentados na Figura 12 indicam que o aquecimento próximo a $170^{\circ} \mathrm{C}$ por um período de $11 \mathrm{~h} 30 \mathrm{~min}$ promoveu um aumento crescente nos valores de absortividade na faixa de $232 \mathrm{~nm}$. Na fritura 07 que atingiu $12 \mathrm{~h} 30 \mathrm{~min}$ de aquecimento, e não sofreu reposição de óleo fresco apresentou um acréscimo significativo no processo de oxidação. Nas frituras 08 (16h20min) e 09 (16h $50 \mathrm{~min}$ ) o período de aquecimento foi curto e as reposições corresponderam de $10 \%$ a $26,6 \%$, ocasionando uma redução dos valores encontrados para absortividades em 232 $\mathrm{nm}$ e em $270 \mathrm{~nm}$. 


\subsubsection{Cor Lovibond}

Pelos valores da tabela 10 observa-se que a intensidade da cor foi significativa neste estudo, portanto, pode-se conceituar esse parâmetro como importante na avaliação da cor do óleo de fritura.

O óleo com 16h20min de fritura apresentou $70 / 5$ (Y/R) de cor, muito mais intensa do que o da fritura de vegetais após 15h25min com 11/7 (Y/R). Possivelmente a passagem dos pigmentos da carne do peixe e o tipo de preparação contribuíram para o escurecimento do óleo, além das partículas de farinha de trigo que se depositaram no interior da fritadeira, e contribuíram para a acentuação da cor.

Lima (1994), fritando vários alimentos de origem animal em fritura intermitente, sem reposição de óleo fresco até 24 horas de aquecimento, encontrou valores de cor Lovibond do óleo de peixe enfarinhado, de 55/5 (Y/R). No estudo de fritura de vegetais o período de $25 \mathrm{~h} 15 \mathrm{~min}$ encontrou-se $15 / 2,7$ (Y/R). A Figura 13 apresenta a progressão da cor no óleo nesta fritura.

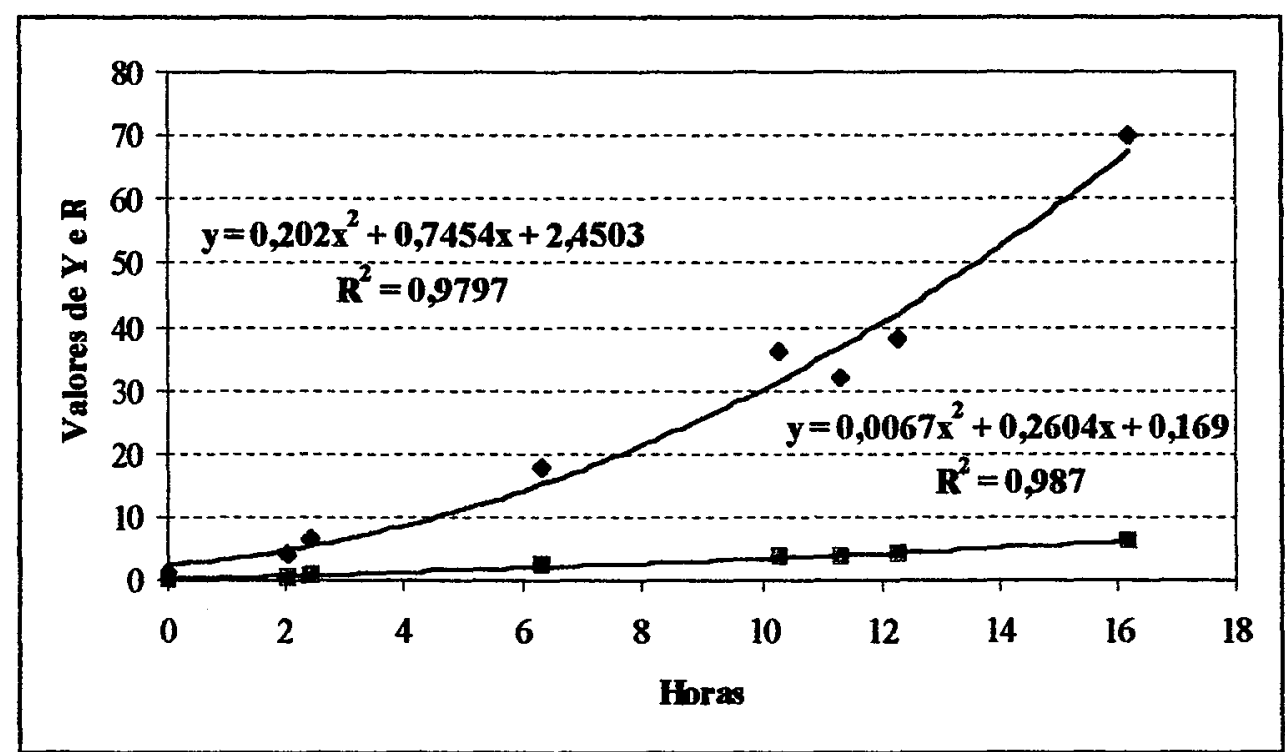

Figura 13 - Cor Lovibond no óleo da fritura de peixe. 
Constata-se que houve um aumento da intensidade da cor, no periodo estudado para o óleo da fritura de peixe.

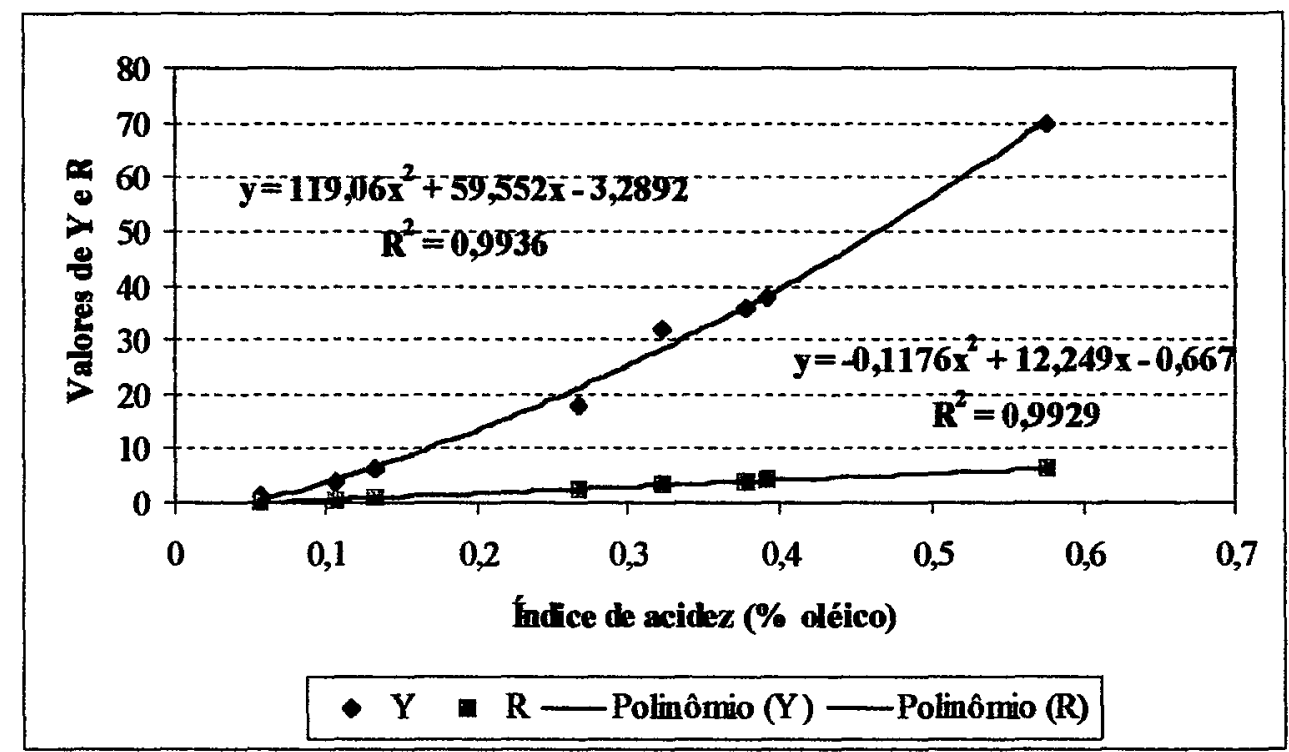

Figura 14 - Correlação entre índice de acidez e cor Lovibond no óleo da fritura de peixe.

No caso do óleo da fritura de peixe, os valores de $\mathrm{Y}$ e $\mathrm{R}$ apresentaram uma excelente correlação com o índice de acidez, indicando que ambas metodologias são eficientes para avaliar o processo de oxidação. $O$ mesmo também pode ser observado na fritura de vegetais, conforme apresentado na Figura 7.

\subsubsection{Análise sensorial}

Neste estudo, o teste de aceitabilidade foi conduzido em 4 períodos, sendo que cada período correspondeu às seguintes horas acumuladas de fritura: $2 \mathrm{~h} 05 \mathrm{~min}$ (fritura 01), 6h30min (fritura 03), 10h30min (fritura 05) e 16h20min (fritura 08). Como o valor de $\mathrm{F}$ foi significativo, realizou-se o teste Tukey. Os resultados estão apresentados na Tabela 11 . 
Tabela 11. Médias das notas do teste de aceitabilidade da fritura de peixe.

\begin{tabular}{ll}
\hline Período & Médias \\
\hline 1 (fritura 01) & $8,1 \mathrm{a}$ \\
2 (fritura 03) & $7,6 \mathrm{ab}$ \\
3 (fritura 05) & $7,8 \mathrm{ab}$ \\
4 (fritura 08) & $7,4 \mathrm{~b}$ \\
\hline Valor F & 4,5 \\
Coeficiente de variação & $9,6 \%$ \\
\hline
\end{tabular}

Médias seguidas por letra distintas diferem entre si em nível de 0,05 de significância.

A figura 15 apresenta a média das notas dos provadores em relação às horas acumuladas que estão representadas por períodos da fritura de peixe.

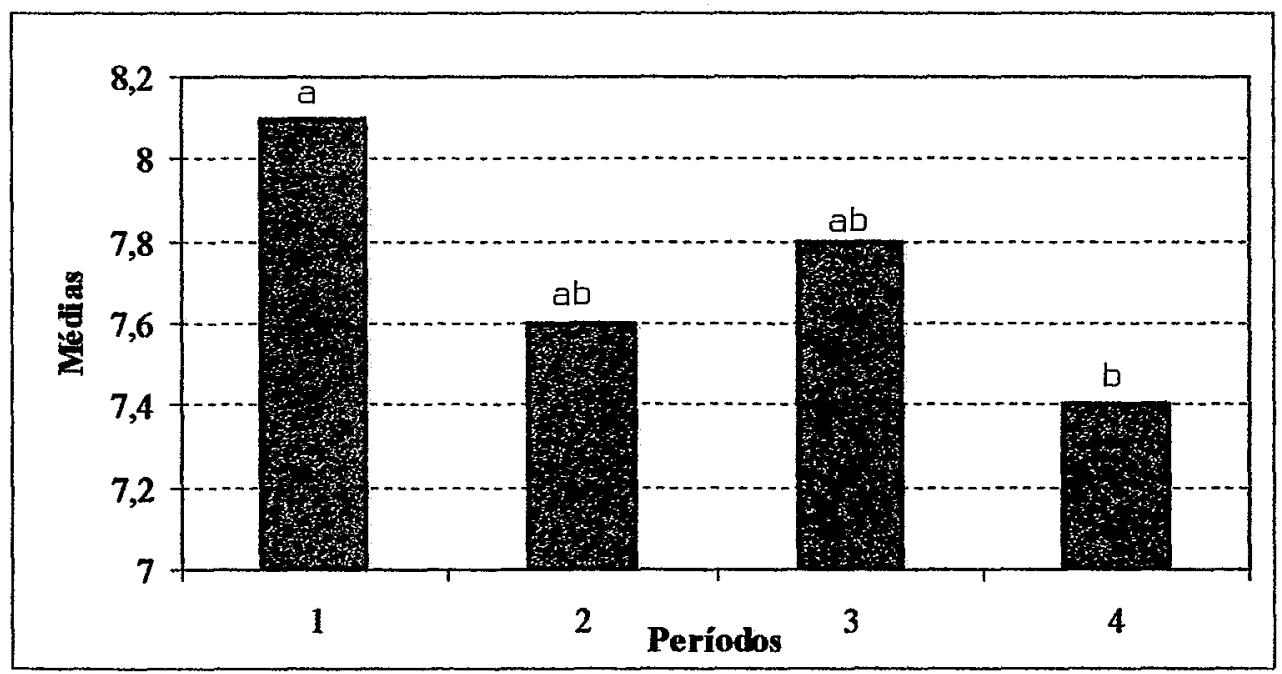

Figura 15 - Comportamento dos provadores em relação à aceitabilidade da fritura de peixe.

Nesse estudo, observou-se que nos três primeiros períodos de fritura, não houve diferenças significativas entre as médias das notas dos provadores para as amostras de peixe, permanecendo dentro da escala "gostei muito" a "gostei 
moderadamente". Somente o $4^{0}$ período de fritura provocou um decréscimo nas notas, com valores em torno de "gostei moderadamente".

Os atributos de textura também não variaram muito, permanecendo, assim como nos vegetais, na categoria "suave", "macio", "crocante", e "seco".

Quanto ao sabor e aroma, permaneceu também o "leve", "suave", "característico" e "saboroso", deixando claro, que, mesmo depois de mais de 16 horas de fritura, o óleo não deixou qualquer alteração de sabor ou odor no peixe.

\subsection{Fritura de frango e carne}

A tabela 12 apresenta a caracterização inicial do óleo de soja A (o mesmo dos ensaios anteriores) e B.

Tabela 12. Características iniciais dos óleos de soja A e B.

\begin{tabular}{lcc}
\hline & Óleo A & Óleo B \\
\hline Índice de acidez (\% ácido oléico) & 0,057 & 0,1242 \\
Compostos polares (\%) & 6,0 & 7,0 \\
Cor Lovibond (Y/R) & $1,3 / 0,2$ & $2,8 / 0,4$ \\
Absortividade em 232 nm & 4,187 & 8,307 \\
Absortividade em 270 nm & 1,473 & 1,031 \\
\hline
\end{tabular}

Ambas frituras (A e B) foram conduzidas sob as mesmas condições, um tipo de óleo, em cada compartimento da fritadeira, portanto, os dados de controle são os mesmos (Tabela 6 ). 
O comportamento das duas marcas de óleo foi semelhante, quando o óleo atingiu 17 horas de fritura as características fisicas do óleo estavam alteradas, a cor apresentava-se intensa (marrom avermelhada), a textura espessa (possivelmente pela passagem da gordura do frango no óleo de fritura) e houve o aparecimento intenso de espuma. Portanto o óleo foi descartado, evitando uma depreciação do alimento frito.

Nas Tabelas 13 e 14 podem ser encontrados os resultados das análises químicas e fisicas da fritura de frango e carne com óleo da soja A e B, respectivamente.

Tabela 13. Características do óleo de soja A durante a fritura de frango e carne.

\begin{tabular}{cccccccc}
\hline $\begin{array}{c}\text { Fritura } \\
\mathbf{n}^{\mathrm{o}}\end{array}$ & R.L. & $\begin{array}{c}\text { Tempo } \\
\text { acumulado }\end{array}$ & $\begin{array}{c}\text { Acidez } \\
\text { \% oléico }\end{array}$ & $\begin{array}{c}\text { Compostos } \\
\text { polares \% }\end{array}$ & $\begin{array}{c}\text { Cor Lovibond } \\
\text { Y / R }\end{array}$ & $\mathrm{A}_{232 \mathrm{~nm}}$ & $\mathrm{~A}_{270 \mathrm{~mm}}$ \\
\hline 01 & 26 & $2 \mathrm{~h} 30 \mathrm{~min}$ & 0,229 & 12,2 & $8,5 / 0,9$ & 6,225 & 1,524 \\
02 & & $2 \mathrm{~h} 55 \mathrm{~min}$ & 0,229 & 15,3 & - & 6,507 & 1,674 \\
03 & 5 & $3 \mathrm{~h} 35 \mathrm{~min}$ & 0,227 & 14,3 & $15,0 / 2,7$ & 6,580 & 1,717 \\
04 & & $4 \mathrm{~h} 15 \mathrm{~min}$ & 0,286 & 17,3 & $14,0 / 1,8$ & 6,714 & 1,714 \\
05 & & $7 \mathrm{~h} 40 \mathrm{~min}$ & 0,296 & 19,1 & $26,0 / 4,1$ & 5,484 & 1,469 \\
06 & & $9 \mathrm{~h} 45 \mathrm{~min}$ & 0,325 & 19,4 & $22,0 / 5,6$ & 6,000 & 1,500 \\
07 & & $10 \mathrm{~h} 45 \mathrm{~min}$ & 0.377 & 21,0 & $32,0 / 6,2$ & 7,230 & 1,620 \\
08 & & $11 \mathrm{~h} 25 \mathrm{~min}$ & 0,397 & 19,8 & - & 7,560 & 1,730 \\
09 & 2 & $15 \mathrm{~h}$ & 0,443 & 21,6 & - & 6,050 & 1,338 \\
10 & & $17 \mathrm{~h}$ & 0,471 & 19,9 & $70,0 / 7,1$ & 6,569 & 1,415 \\
\hline
\end{tabular}

(-) determinação não realizada

R.L: reposição em latas 
Tabela 14. Características do óleo de soja B durante a fritura de frango e carne.

\begin{tabular}{|c|c|c|c|c|c|c|c|}
\hline $\begin{array}{c}\text { Fritura } \\
n^{\circ}\end{array}$ & R.L. & $\begin{array}{c}\text { Tempo } \\
\text { acumulado }\end{array}$ & $\begin{array}{c}\text { Acidez } \\
\% \text { oléico }\end{array}$ & $\begin{array}{l}\text { Compostos } \\
\text { polares \% }\end{array}$ & $\begin{array}{c}\text { Cor Lovibond } \\
\text { Y / R }\end{array}$ & $A_{232 n m}$ & $\overline{\mathbf{A}_{270 \mathrm{~nm}}}$ \\
\hline 01 & 26 & $2 \mathrm{~h} 30 \mathrm{~min}$ & 0,1625 & 11,9 & $13,0 / 2,3$ & 8,152 & 1,168 \\
\hline 02 & & $2 \mathrm{~h} 55 \mathrm{~min}$ & 0,1869 & 16,5 & - & 8,377 & 1,278 \\
\hline 03 & 5 & $3 \mathrm{~h} 35 \mathrm{~min}$ & 0,2017 & 14,3 & $18,0 / 3,0$ & 8,269 & 1,261 \\
\hline 04 & & $4 \mathrm{~h} 15 \mathrm{~min}$ & 0,2286 & - & $20,0 / 3,5$ & 8,539 & 1,406 \\
\hline 05 & & $7 \mathrm{~h} 40 \mathrm{~min}$ & 0,2693 & 15,8 & $38,0 / 6,4$ & 8,865 & 1,622 \\
\hline 06 & & $9 \mathrm{~h} 45 \mathrm{~min}$ & 0,3756 & 19,5 & $24,0 / 7,2$ & 8,872 & 1,633 \\
\hline 07 & & $10 \mathrm{~h} 45 \mathrm{~min}$ & 0,3759 & 18,9 & $70,0 / 7,5$ & 9,622 & 1,790 \\
\hline 08 & & $11 \mathrm{~h} 25 \mathrm{~min}$ & 0,4033 & 18,9 & - & 9,092 & 1,792 \\
\hline 09 & 2 & $15 \mathrm{~h}$ & 0,4845 & 19,3 & $70,0 / 8,1$ & 8,021 & 1,748 \\
\hline 10 & & $17 \mathrm{~h}$ & 0,4970 & 19,5 & - & 8,575 & 1,590 \\
\hline
\end{tabular}

(-) determinação não realizada

R.L: reposição em latas

\subsubsection{Acidez}

Observaram-se diferenças significativas na qualidade inicial do óleo A e B. Neste tipo de fritura as reposições foram muito pequenas, o próprio alimento contribuiu com seus lipídeos endógenos para o óleo de fritura e consequentemente a estabilidade oxidativa da nova mistura provavelmente foi diferente da do óleo em outras condições. Durante a fritura de vegetais o indice de acidez atingiu, 0,2832, na fritura de peixe, 0,4735 , após $15 \mathrm{~h}$, enquanto, que na fritura de frango e carne atingiu 0,4435 (A) e 0,4845 (B). 
Nas figuras 16 e 17 podem ser encontrados os resultados do índice de acidez (\% em ácido oléico) dos óleos de fritura de A e B, respectivamente.

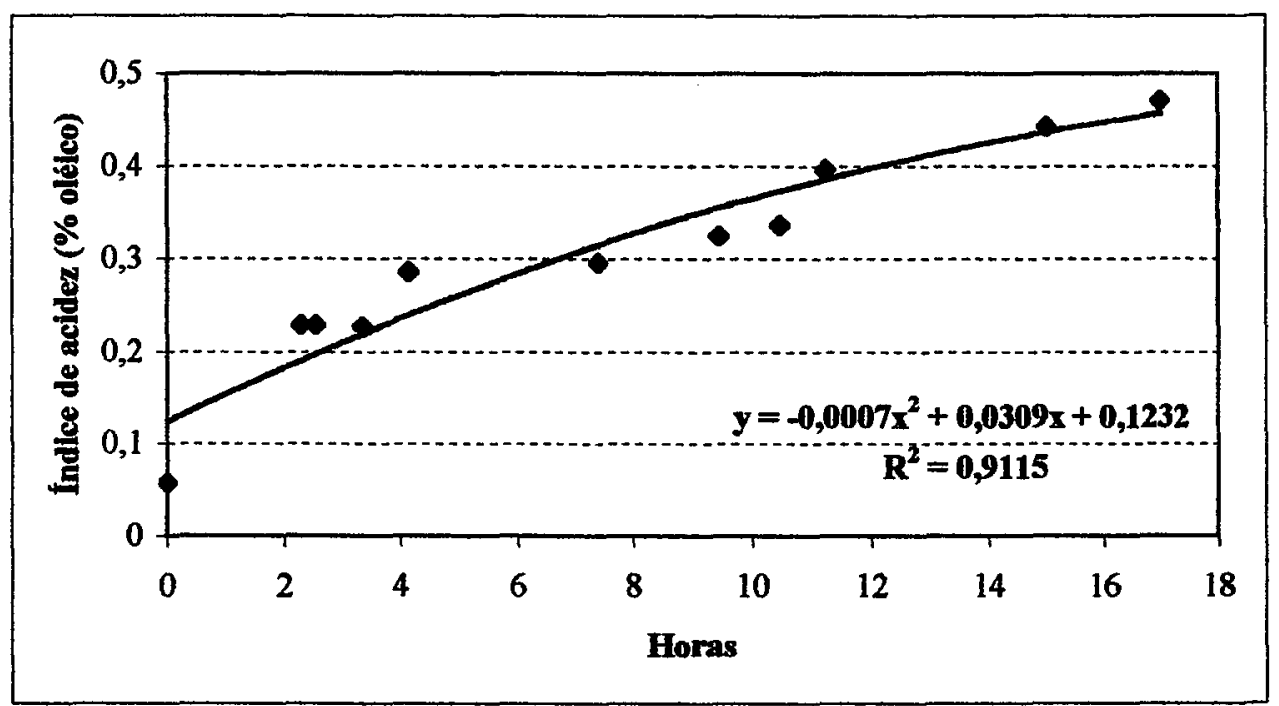

Figura 16 - Índice de acidez no óleo A da fritura de frango e carne.

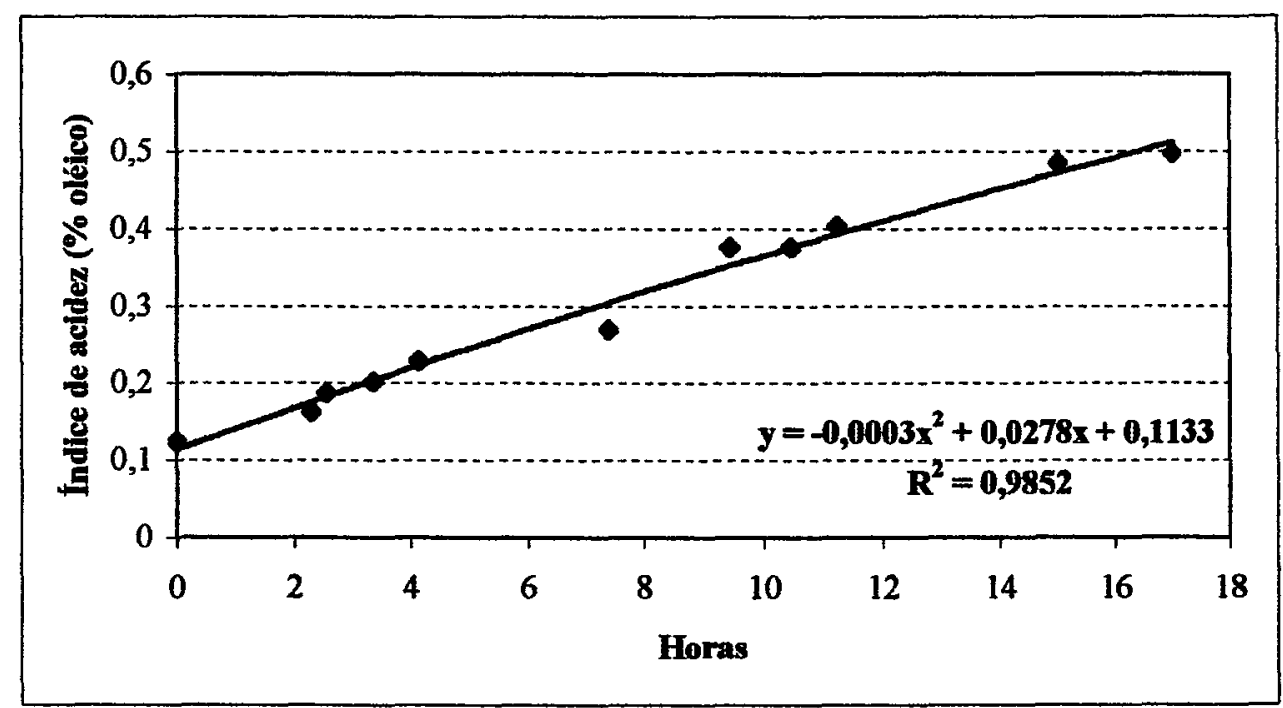

Figura 17 - Índice de acidez no óleo B da fritura de frango e carne. 
$\mathbf{O}$ indice de acidez sofreu aumentos gradativos e significativos nas frituras A e B, pode-se observar o desenvolvimento das reações hidrolíticas. No decorrer das frituras ambos os óleos apresentaram índice de acidez com valores próximos, apesar de o óleo B apresentar resultados iniciais superiores ao do óleo A.

\subsubsection{Compostos polares}

Este é um índice importante pois a formação de teores superiores a $25 \%$ de compostos polares em óleo e gorduras pode provocar comprometimento da saúde.

A taxa de formação de compostos de decomposição modifica-se conforme o alimento que está sendo frito, o óleo, o tipo da fritadeira $e$ as condições de operação. Estas variáveis fazem com que seja dificil determinar exatamente o que ocorre durante $\mathrm{o}$ processo de fritura. Algumas reações químicas que ocorrem durante $\mathrm{o}$ processo de fritura são diferentes daquelas que ocorrem em estudos onde o óleo é aquecido continuamente, portanto, este tipo de estudo pode não ser representativo daquilo que ocorre em condições normais de fritura (Stevenson et al., 1984).

As figuras 18 e 19 apresentam o comportamento dos compostos polares nas frituras de óleo $\mathrm{A}$ e B, respectivamente. 


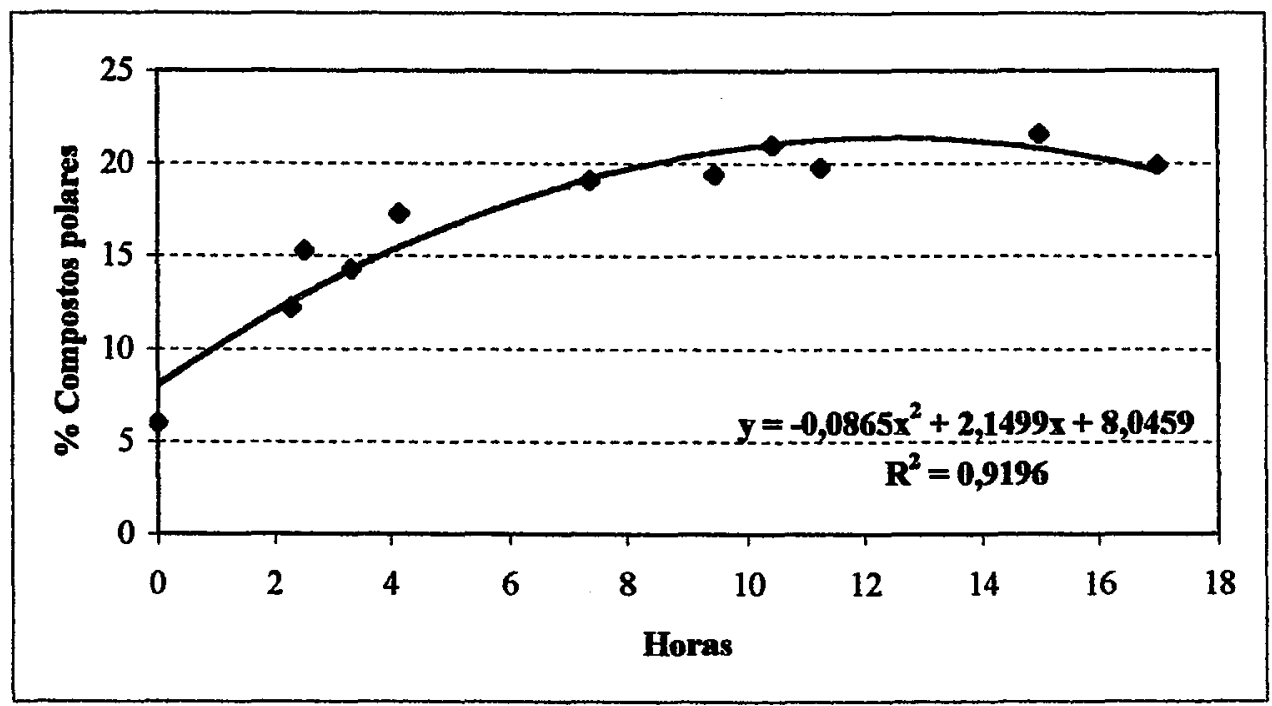

Figura 18 - Teor dos compostos polares no óleo A da fritura de frango e carne.

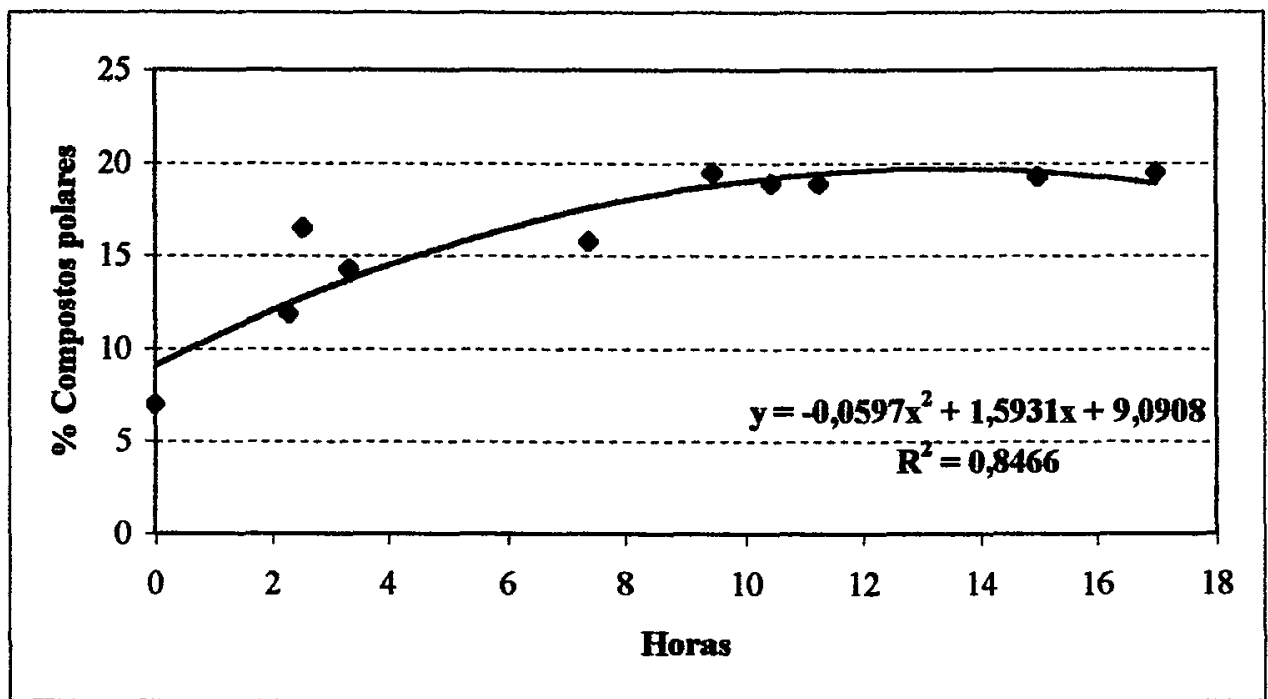

Figura 19 - Teor dos compostos polares no óleo B da fritura de frango e carne.

Pode-se observar que a porcentagem de compostos polares totais elevouse em apenas $2 \mathrm{~h} 30 \mathrm{~min}$ de aquecimento a $170^{\circ} \mathrm{C}$, atingindo valores de $12 \%$, em ambos óleos, e na seqüência do estudo os valores também foram próximos. 
Os valores alcançados nos óleos de fritura A e B em $17 \mathrm{~h}$ de aquecimento foram de aproximadamente $20 \%$, que, comparados com a fritura de vegetais que atingiu este valor em aproximadamente 30 horas, são bastante altos.

A fritura por imersão é um processo de cocção em que é utilizado calor seco por meio indireto, cuja ação é a desidratação do alimento. Pelo aumento da temperatura não somente a gordura da pele do frango, como também a intrafascicular, fundem-se e passam a fazer parte do meio de cocção. Este índice foi facilmente alcançado provavelmente pela baixa rotatividade de óleo fresco e também pela nova composição do óleo devido aos lipídeos endógenos do frango.

A determinação do teor de compostos polares totais em óleos de fritura através da separação em coluna de cromatográfia usando sílica como adsorvente, é um método simples, mas, não é tão rápido e de tão fácil reprodutividade, conforme relatado por vários autores.

As figuras 20 e 21 apresentam a correlação entre o teor de compostos polares e o índice de acidez, nos óleos A e B. 


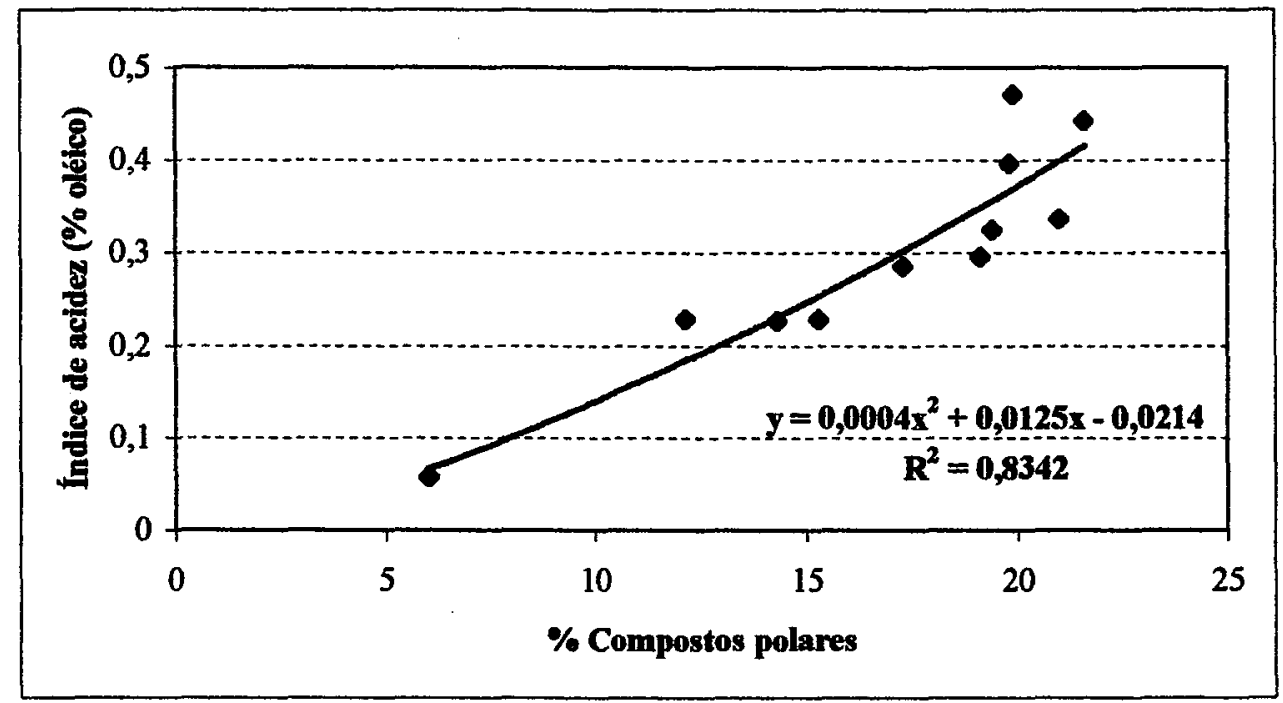

Figura 20 - Correlação entre o teor de compostos polares e o índice de acidez no óleo A da fritura de frango e carne.

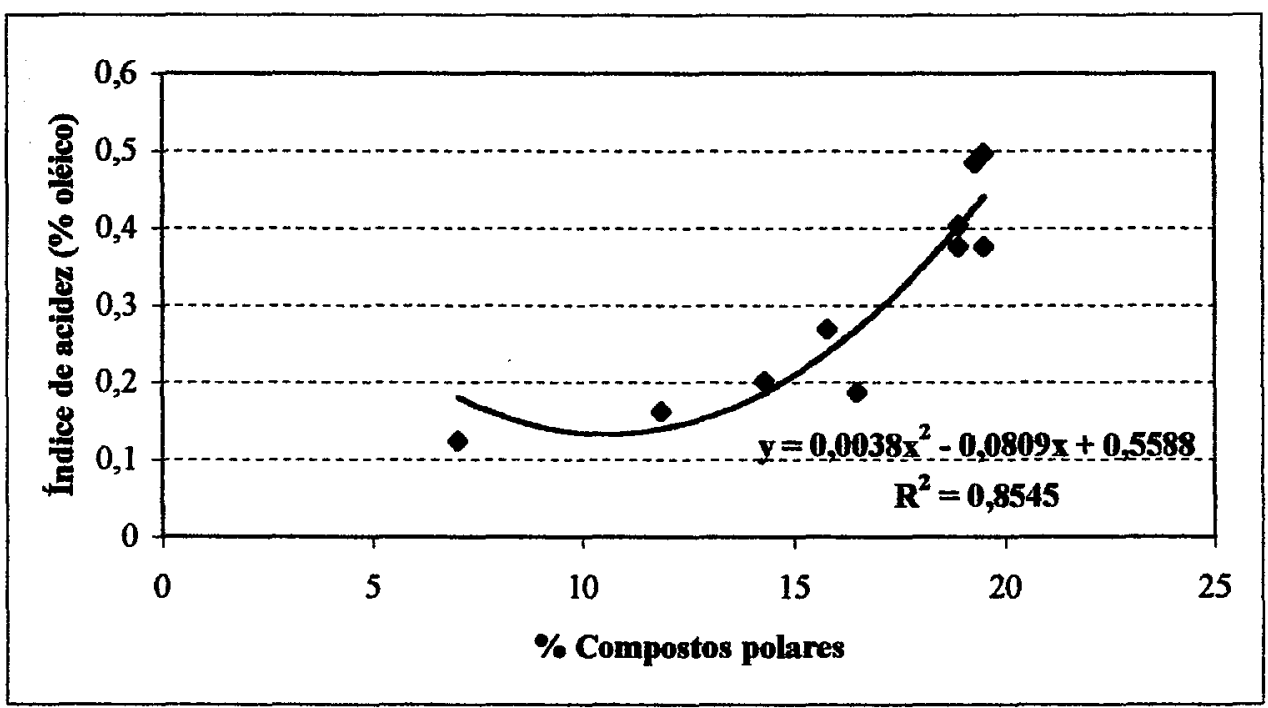

Figura 21 - Correlação entre o teor de compostos polares e o índice de acidez no óleo B da fritura de frango e carne.

\subsubsection{Absortividade na faixa do ultravioleta}

As Figuras 22 e 23 apresentam os espectros de absortividade dos óleos A e B, respectivamente, ao final de cada período de fritura. 


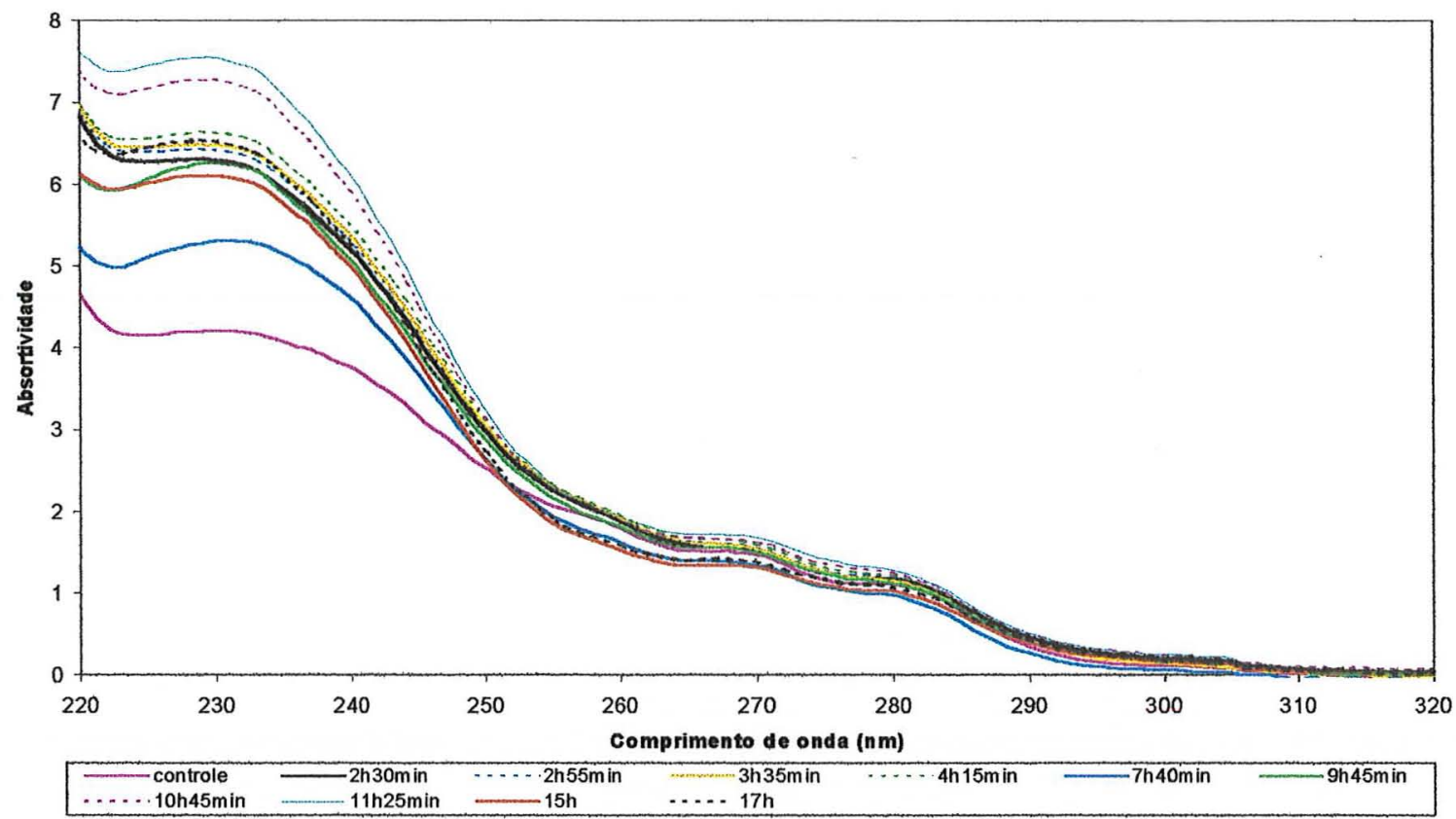

Figura 22 - Espectro de absortividade na faixa do UV no óleo A da fritura de frango e carne.

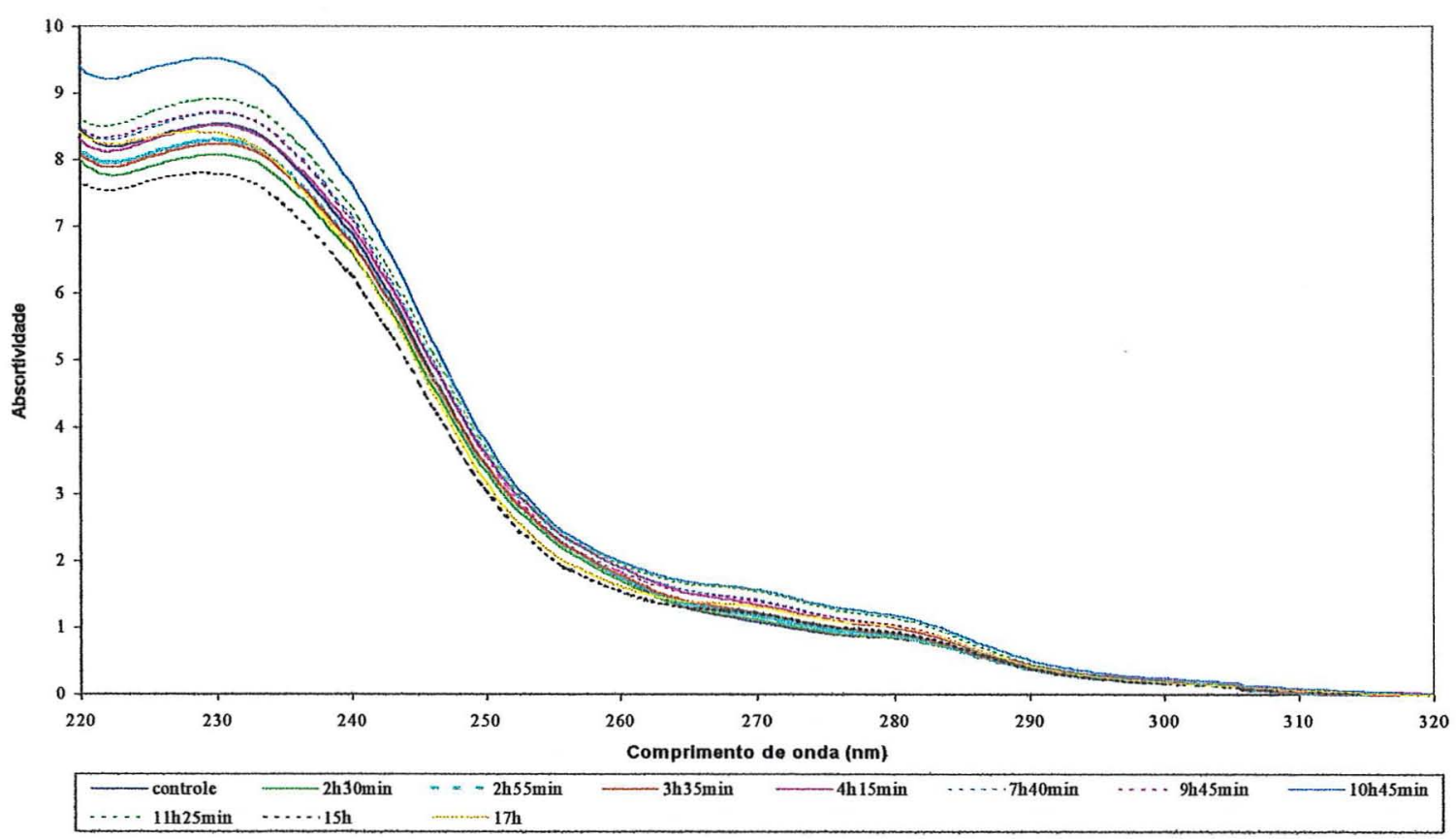

Figura 23 - Espectro de absortividade na faixa do UV no óleo B da fritura de frango e carne. 
O comportamento irregular das curvas do óleo da fritura de frango e carne, em contraposição à similaridade das curvas observada nas frituras de peixe e de vegetais, talvez possa ser explicada pela incorporação da gordura do frango, de composição mais saturada, no óleo de fritura, alterando o tipo de compostos decorrentes das reações de termoxidação.

\subsubsection{Cor Lovibond}

Como pode ser observado durante o processo de fritura, o óleo tende a escurecer, mas os pigmentos responsáveis pela coloração da carne, como a mioglobina e a hemoglobina, são fatores importantes na cor do óleo de fritura.

As tabelas 13 e 14 apresentaram os valores de $\mathrm{Y}$ e $\mathrm{R}$ referentes à cor Lovibond, para os óleos A e B que foram aquecidos em temperatura controlada por diferentes períodos. A partir desses resultados observa-se que no decorrer do estudo houve diferenças de comportamento entre os óleos A e B. Com o aumento do período de aquecimento as amostras após 15 horas passaram a ter características de cores semelhantes.

Lima (1994) fritou vários alimentos na mesma fritadeira com capacidade de 200 litros de óleo. Nas primeiras 6 horas fritou frango e encontrou valores para cor Lovibond de 9/0,9 (Y/R), enquanto o encontrado neste estudo após 7h40min foi para o óleo A, 26/4,1 (Y/R) e para o óleo B, 38/6,4 (Y/R). Parece que o modelo e a capacidade da fritadeira tiveram grande influência neste parâmetro. As Figuras 24 e 25 apresentam a progressão das cores $\mathrm{Y}$ e $\mathrm{R}$, nos óleos A e B, respectivamente. 


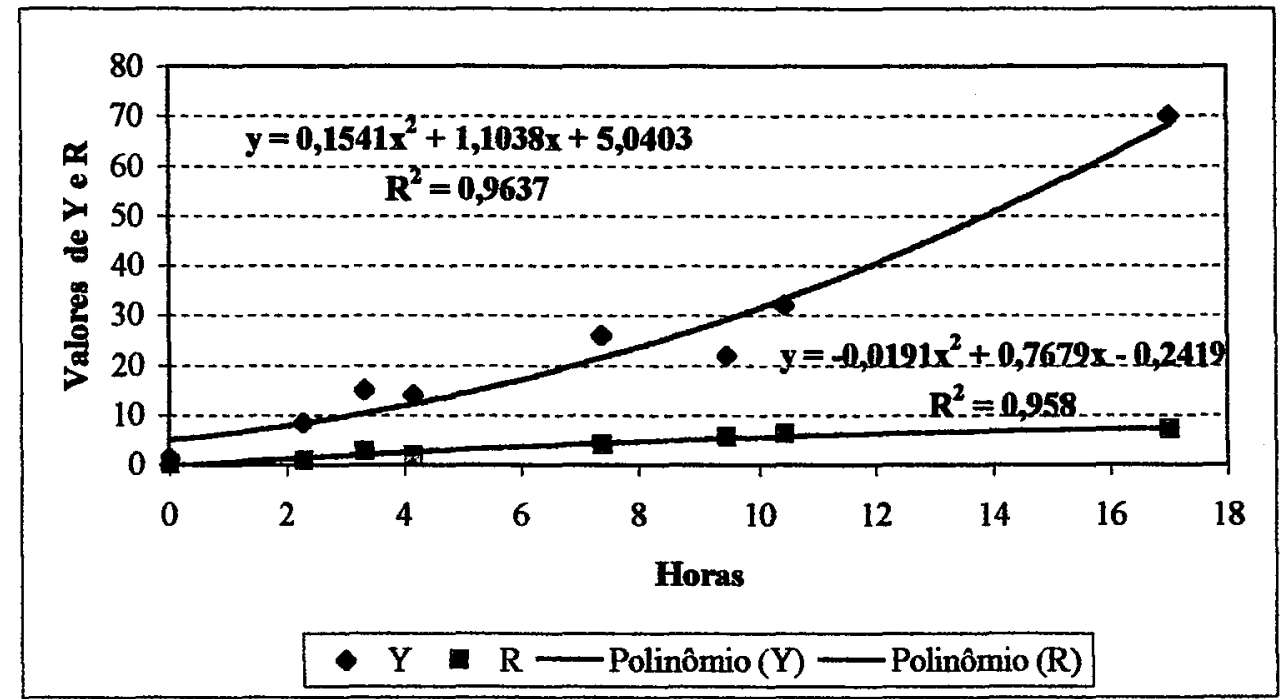

Figura 24 - Cor Lovibond no óleo A da fritura de frango e carne.

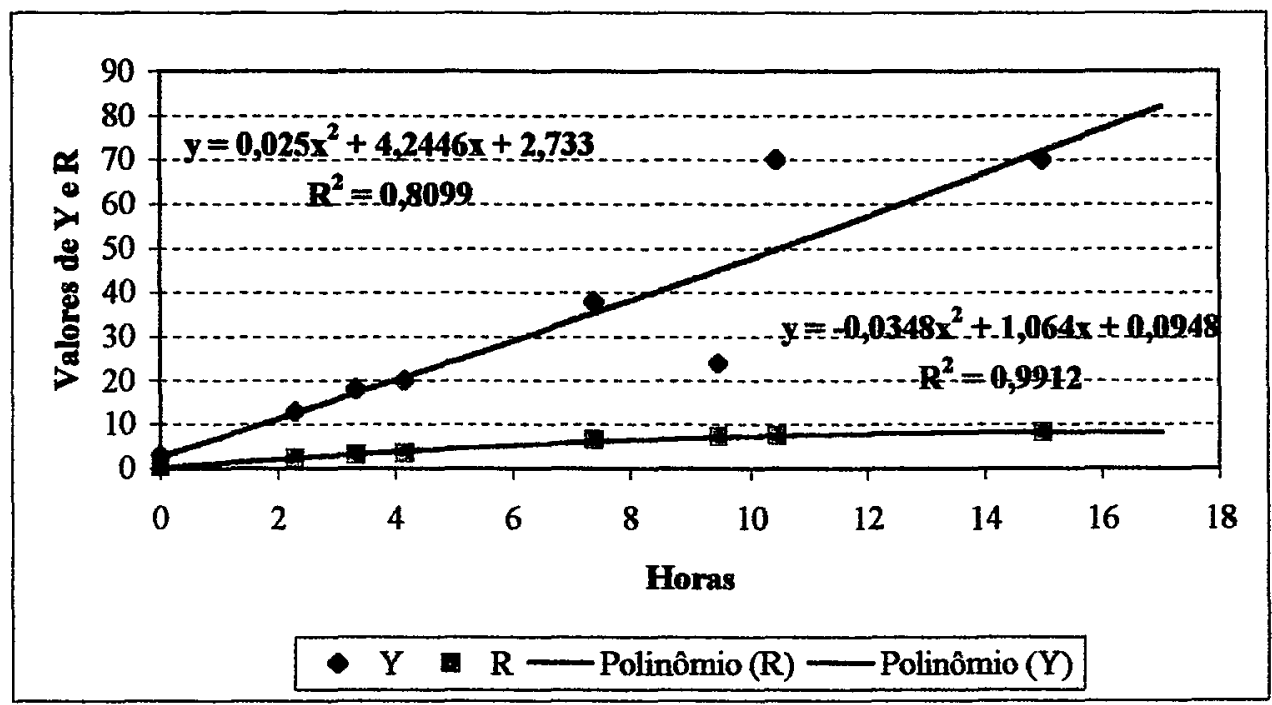

Figura 25 - Cor Lovibond no óleo B da fritura de frango e carne.

Todos os óleos da fritura apresentaram um aumento da intensidade da cor com o aumento do período de aquecimento. 
As Figuras 26 e 27 apresentam a correlação existente entre o índice de acidez (\% em ácido oléico) e a cor Lovibond, dos óleos A e B da fritura de frango e carne, respectivamente.

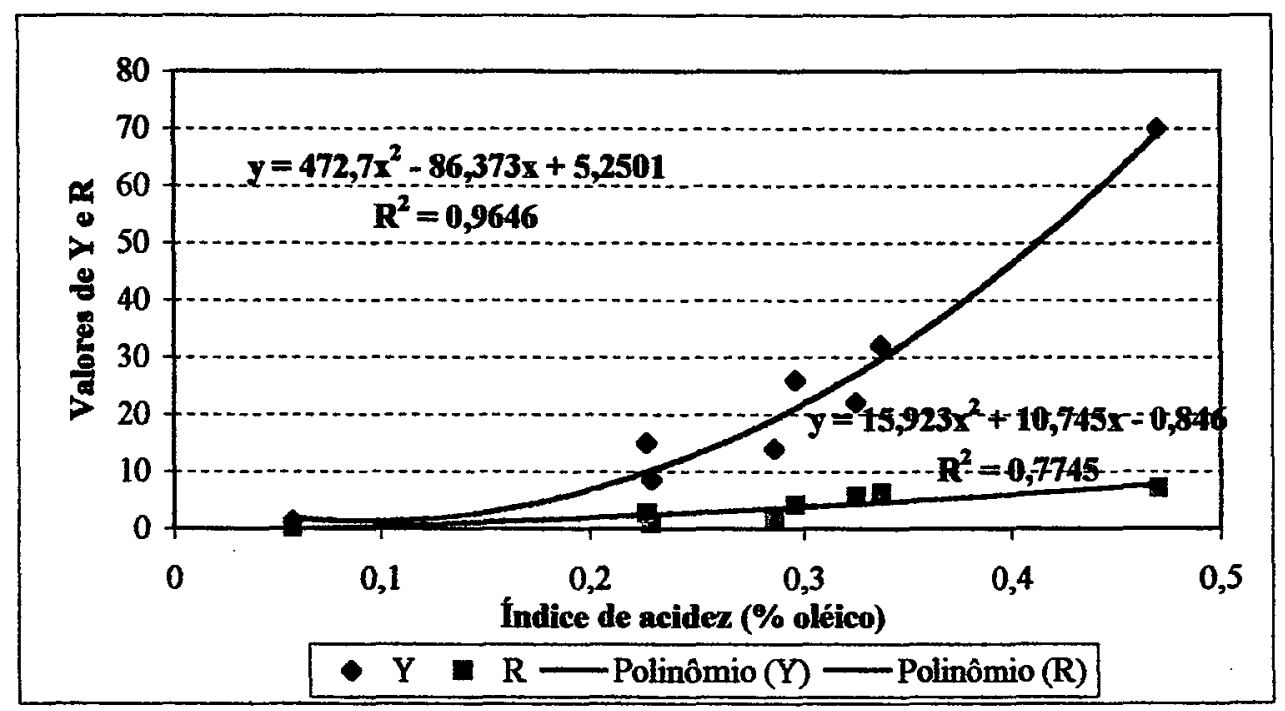

Figura 26 - Correlação entre o índice de acidez e cor Lovibond no óleo A da fritura de frango e carne.

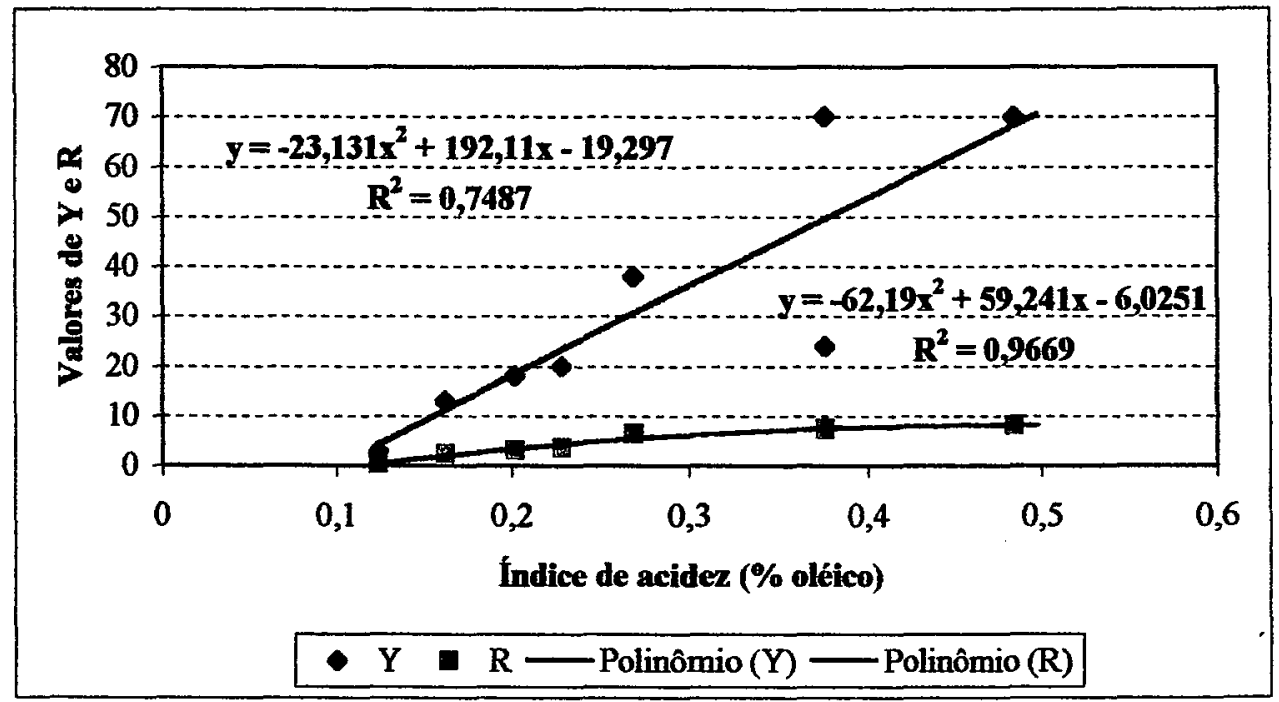

Figura 27 - Correlação entre o índice de acidez e cor Lovibond no óleo B da fritura de frango e carne. 
A cor amarela seguiu melhor a equação polinomial do óleo A enquanto, que a vermelha seguiu a do óleo B.

\subsubsection{Análise sensorial}

O teste de aceitabilidade foi aplicado somente aos alimentos que foram fritos no óleo de soja A. Esta etapa foi conduzida em 3 períodos, cada período correspondeu às seguintes horas acumuladas das frituras: $2 \mathrm{~h} 30 \mathrm{~min}$ (fritura 01 ), $9 \mathrm{~h} 45 \mathrm{~min}$ (fritura 06) e 15horas (fritura 09). Como o valor de F foi significativo, realizou-se o teste Tukey. Os resultados estão apresentados na tabela 15 .

Tabela 15. Médias das notas do teste de aceitabilidade da fritura de frango e carne.

\begin{tabular}{ll}
\hline Períodos & Médias \\
\hline 1 (fritura 01) & $8,0 \mathrm{a}$ \\
2 (fritura 06) & $6,88 \mathrm{~b}$ \\
3 (fritura 09) & $7,64 \mathrm{a}$ \\
\hline Valor F & 10,14 \\
Coeficiente de variação & $12,07 \%$ \\
\hline Médias seguidas por letras distintas diferem entre si em nível de 0,05 de significância.
\end{tabular}

A Figura 28 apresenta o comportamento dos provadores em relação ao alimento frito durante 15 horas de fritura. 


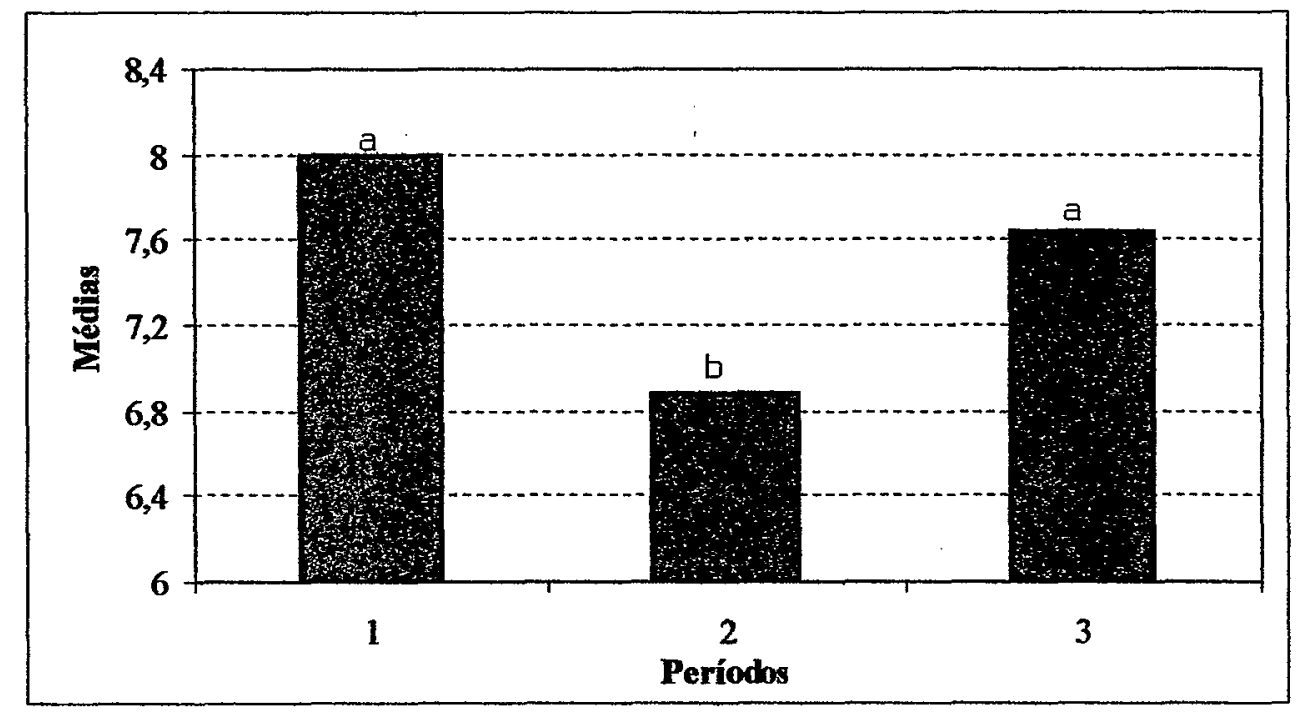

Figura 28 - Comportamento dos provadores em relação à aceitabilidade da fritura de frango e carne.

Embora as amostras tenham obtido notas mais altas de aceitabilidade para o primeiro período de fritura, essas notas não diferiram do terceiro período, cujo óleo já estava com 15 horas de fritura.

Observa-se pela Tabela 15, que durante o período das frituras, as médias das notas oferecidas pelos provadores estiveram dentro do intervalo de "gostei muito" a "gostei ligeiramente" (APÊNDICE 2).

Foram constatados novamente os atributos "seco" e "crocante", para a textura da amostras, em todos os períodos de fritura.

Embora o aroma e sabor fossem caracterizados por "leve" e "suave", no primeiro período de fritura o óleo não afetou as características sensoriais do alimento, $\mathrm{e}$ em nenhum dos períodos, foi observado o odor e sabor de ranço, normalmente esperado. 


\section{CONCLUSÕES}

As determinações analíticas foram úteis para acompanhar as reações da oxidação nas três categorias dos alimentos estudados. Os resultados se apresentaram dentro dos limites aceitos pela regulamentação da Espanha e dos Estados Unidos.

O desenvolvimento do processo oxidativo nas condições executadas não afetou as características sensoriais. Em nenhum dos períodos foi observado o odor e sabor de ranço, e os alimentos fritos foram bem aceitos pelos provadores até o final dos experimentos, através do teste de aceitabilidade.

Para as condições do ensaio, isto é, capacidade e modelo da fritadeira, temperatura controlada, origem do alimento, freqüência da reposição de óleo novo, acondicionamento do óleo usado, pode-se recomendar o uso desse óleo da fritura de vegetais por 30 horas e dos óleos da fritura de peixe, frango e carne por 17 horas de uso intermitente. 


\section{REFERÊNCIAS BIBLIOGRÁFICAS}

AMERICAN OIL CHEMISTS' SOCIETY. Official methods and recommended practices. 4.ed. Champaign, 1990/1991.

ANS, V.G.; MATTOS, E.S.; JORGE, N. Avaliação da qualidade dos óleos de fritura usados em restaurantes, lanchonetes e similares. Boletim Sociedade Brasileira de Ciência e Tecnologia dos Alimentos, v.19, n.3, p.413-419, 1999.

ANUÁRIO DA AGRICULTURA BRASILEIRA. Oferta e demanda brasileiras e mundiais de soja e óleo de soja. p.500-504. 2000.

ASSOCIAÇÃO BRASILEIRA DAS INDÚSTRIAS DE ÓLEOS VEGETAIS. A Abiove. http://www.abiove.com.br/abiov.html. 01/05/2000.

ASSOCIATION OFFICIAL ANALYTICAL CHEMISTS. Official methods of analysis. 14. ed. Arlington, 1995. cap.41, p.24.

AMERINE, M.A.; PANGBORN, R.M.; ROESSLER, E.B. Principles of sensory evaluation of food. Academic Press: New York, 1965. p.1-22. 
BARRERA-ARELANO, D. Estabilidade em óleos e gorduras. Óleos \& Grãos, n.13, p.10-13, 1993.

BERGER, K. G. The practice of frying. Porim Technology, v.9, n.5, p.1-34, 1984.

BILLEK.G. Heated fats in the diet. In: PADLEY, F. B.; PODMORE. J (Eds). The role of fats in human nutrition. Chichester: Ellis Horwood, 1985. cap. 12, p.163-172.

BOGNAR, A. Comparative study of frying to other cooking techniques influence on the nutritive value. Grasas y Aceites, v.49, n.3-4, p.250-260, 1998.

BROOKS, D.D. Deep-fat frying: some perspective on a simple process. Inform, v.2, n.12, p.1091-1095, 1991.

BLUMENTHAL, M.M. una nueva perspectiva en la química y fisica de las frituras por inmersion. Alimentaria, v.5, n.9, p.65-70, 1991.

BUZZETTI, A.R. Agroindústria brasileira é competitiva. Óleos \& Grãos, v.8, n.41, p.6$14,1998$.

CANZIANI, J.R.F. Óleos vegetais produção mundial. Óleos \& Grãos, v.5, n.23, p.39$40,1995$.

CUESTA, C., MUÑIZ, S, F.J. Alteración de aceites de girasol en frituras realizadas con o sin reposición de aceites sin usar. Alimentación, Equipos y Tecnologia, v.4, p.39-43, 1994.

CUESTA, C., MUÑIZ, S.F.J. Quality control during repeated fryings. Grasas y Aceites, v.49, n.3-4, p.310- 318, 1998. 
DANA, B.O. Manual de laboratório de ciência de los alimentos. Zaragoza Acribia, 1992. cap.4, p.15-20.

DOBARGANES, M.C., PEREZ-CAMINO, M.C., MÁRQUEZ-RUIZ, G. Determinación de compuestos polares en aceites y graxas de fritura. Grasas y Aceites, v.40, n.1, p.35-38, 1989.

DOBARGANES, M.C., PEREZ-CAMINO, M.C., GUTIÉRREZ- GONZÁLES, R. Métodos analíticos de aplicación en grasas calentadas. I Determinación de ésteres metílicos no alterados. Grasas y Aceites, v.35, n.3, p.172-177, 1984.

DUTCOSKY, S.D. Análise sensorial de alimentos. Curitiba: Champagnat, 1996. 123p.

ESPINOZA - ATENCIA, E.J.; FARIA, J.A. F. Fotoxidação de óleos comestíveis em embalagens plásticas transparentes. Óleos \& Grãos, v.4, n. 19, p.44-51, 1994.

FEDELI, E. The behaviour of olive oil during cooking and frying. In: Varela G., Bender, A.E.; Morton, I.A. (Ed) Frying of food: principles, changes, new approaches. Chichester: Ellis Horwood, 1988. p.52-81.

FIRESTONE, D.; STIER, R.F.; BLUMENTHAL, M.M. Regulation of frying fats and oils. Food Technology, v.45, n.2, p.90-94, 1991.

FRITSCH, C.W. Measurements of frying fat deterioration: a brief review. Journal of the American Oil Chemists' Society, v.5, n.3, p.272-274, 1981.

GONÇALVES, L. Mitos e verdades sobre sua reutilização. CRN-3 Notícias, n.47, p.49, abr./maio/jun. 1997. 
GRAY, J.I. Measurement of lipid oxidation: a review. Journal of the American Oil Chemists' Society, v.55, n.6, p.539-546, jun. 1978.

GRISWOLD, R. Estudo experimental dos alimentos. Rio de Janeiro: Edgard Blücher, 1972. cap.8, p.200-227: Gorduras.

HELLÍN, L.C.; CLAUSELL, M.P.R. Incidencia de la fritura en la composition de fraccion lipidica de diversos aperitivos de consumo generalizado en nuestro pais. I. Transformaciones de los aceites durante la fritura. Anales de Bromatologia v.36, n. 1, p.5-31, 1984.

INTERNATIONAL UNION OF PURE AND APPLIED CHEMISTRY. Standard methods for the analysis of oils, fats and derivatives. 7.ed. Boston, 1987.

JORGE, N. Estudos do comportamento do óleo de girassol e do efeito do dimetil polisiloxano em frituras. Campinas, 1996. 233p. Tese (Doutorado ) - Faculdade de Engenharia de Alimentos, Universidade Estadual de Campinas.

LABUZA, T.P. Kinetics of lipid oxidation in foods. Critical Reviews in Food Technology, v.10, p.355-405, 1971.

LIMA, J.R.; GONÇALVES, L.A.G. Avaliação da qualidade de óleo de soja utilizado para fritura. Campinas, 1994. 60p. Tese (Mestrado) - Faculdade de Engenharia de Alimentos, Universidade Estadual de Campinas.

LIMA, J.R.; GONÇALVES, L.A.G. Avaliação analítica de óleos utilizados em processos de fritura. Boletim Sociedade Brasileira de Ciência e Tecnologia dos Alimentos, v.29, n.2, p.186-192, jul/dez. 1995. 
LIMA, J.R.; GONÇALVES, L.A.G. O processo de frituras: alterações observadas em óleos e gorduras. Boletim Sociedade Brasileira de Ciência e Tecnologia dos Alimentos, v.29, n.2, p.179-185, jul/dez. 1995.

MÁRQUES-RUIZ, G., PÉREZ-CAMINO, M.C., DOBARGANES, M.C.. Evaluación nutricional de grasas termoxidadas y de fritura. Grasas y Aceites, v.41, n.6, p.432439, 1990.

MELTON, S.L.; JAFAR, S.; SYKES, D.; TRIGIANO, M.K. Review of stability measurements for frying oils and fried food flavor. Journal of the American Oil Chemists' Society, v.71, n.12, p.1301-1308, 1994.

MONFERRER, A.; VILLATA, J. La fritura desde un punto de vista práctico 1. Alimentación Equipos y Tecnologia, v.21, n.3, p.85-90, 1993.

MORAES, M.A.C. Métodos para avaliação sensorial dos alimentos. 8. ed. Campinas: Ed. Unicamp, 1993, 93p.

MORETTI, R.B. Desenvolvimento de uma gordura para pré-fritura, de alta performance, à base de óleo de soja. Campinas, 1997. 91p. Tese (Mestrado) - Faculdade de Engenharia de Alimentos, Universidade Estadual de Campinas.

MORETTO, E; ALVES, A.F. Óleos e gorduras vegetais: processamento e análises. Florianópolis: UFSC, 1986. cap.6, p.109: Comportamento dos óleos e gorduras na fritura.

MORETTO, E ; BARRERA-ARELLANO, D. Estabilidade oxidativa e comportamento térmico de misturas de oleína de palma e óleos vegetais. Óleos \& Grãos, v.5, n.23, p.19-21, 1995. 
MORI, E.E.M. Análise sensorial de óleos e gorduras. Óleos \& Grãos, v.4, n.19, p.1927, 1994.

MORI, E.E.M.; SHIROSE, I.; FERREIRA, V.; CAMPOS, S. Métodos sensoriais e físicos para avaliação de alimentos e bebidas: princípios e aplicação. Campinas: ITAL, 1992. p.irreg.

OBRETENOV, T.D.; IVANOVA,S.D.; KUNTCHEVA,M.J.; SOMOV, G.T. Melanoidin formation in cooked meat products. Journal of Agricultural Food Chemistry, v.41,n.4, p.653-656, 1993.

PARRA, C.D. Analisa gordura hidrogenadas para frituras. Óleos \& Grãos, v.5, n.22, p.5-12, 1995.

PEERS, K.E.; SWOBODA, P.A.T. Deterioration of sunflower seed oil under simulated frying conditions and during small-scale frying of potato. Journal Science Food Agriculture., v.33, n.4, p.389-395, 1982.

PERKINS, E,G.; AKKEREN, V.L.A. Heated fats. IV. Chemical changes in fats subjected to deep fat frying processes: cottonseed oil. Journal American Oil Chemists' Society, v.42, n.9, p.782-786, 1965.

PÉREZ-CAMINO, M.C., MÁRQUES-RUIZ, G., SALGADO-RAPOSO, A., DOBARGANES, M.C. Alteración de grasas usadas en fritura III. Correlación entre indices analíticos y métodos de evaluación directa de compuestos de degradación. Grasas y Aceites, v.39, n.2, p.72-76, 1988.

PIMENTEL, G.F. Curso de estatística experimental. 13.ed. São Paulo: Nobel, 1990. 468p. 
ROHR, R. Mercado atual de óleos no Brasil. Óleos \& Grãos, n.12, p.10, 1993.

ROSSELL, J.B. Industrial frying process. Grasas y Aceites, v.49, n.3-4, p.282-295, 1998.

ROVELLINI, P.; CORTESI, N.; FEDELI, E. Ossidazioni dei lipidi. Nota 1. La Rivista Italiana delle Sostanza Grasse, v.74, n.5, p.181-189. Mag. 1997.

SHAHIII, F. Stability of fats and olis. In: LATIN AMERICAN CONGRESS AND EXHIBIT ON FATS AND OILS PROCESSINGS, 6., Campinas, 1995. Proceedings. Campinas: Sociedade Brasileira de Óleos e Gorduras, 1995. p.47-54.

SMITH, L.M.; CLIFFORD, A.J.; HAMBLIN, C.L., CREVELING, R.K. Changes in physical and chemical properties of shortenings used for commercial deep-fat frying. Journal of the American Oil Chemists' Society, n v.63, n.8, p.1017-1023, 1986.

STAZIONE SPERIMENTALE PER INDUSTRIE DEGLI OLI E DEI GRASSI. Norme italiane per il controllo dei grassi e derivati, 3.d. Milano, 1976.

STEVENSON, S.G.; VAISEY-GENSER, M.; ESKIN, N.A.M. Quality control in the use of deep frying oils. Journal of the American Oil Chemists' Society, v.61, p.1102$1108,1984$.

VARELA, G., MOREIRAS-VARELA, O., RUIZ-ROSO, B. Utilización de algunos aceites en friturąs repetidas. Cambios en las grasa y análisis sensorial de los alimentos fritos. Grasas y Aceites, v.34, n.2, p.101-107, 1983. 
WARNER, K. Sensory evaluation of oils and fat containing foods. In: WARNER, K.; ESKIN, N.A.M. (Eds). Methods to assess quality and stability of oils and fatcontaining foods, Champaign: AOCS, 1995. cap 4. p.49-75.

WESSELS, $\mathrm{H}$. Results of a collaborative study on determination of polar compounds in frying fats. Pure \& Applied Chemistry, v.55, n.8, p.1381-1385, 1983.

WHITE, P.J. Methods for measuring changes in deep-fat frying oils. Food Techonology, v.45, n.2, p.75-80, 1991. 
APÊNDICE 


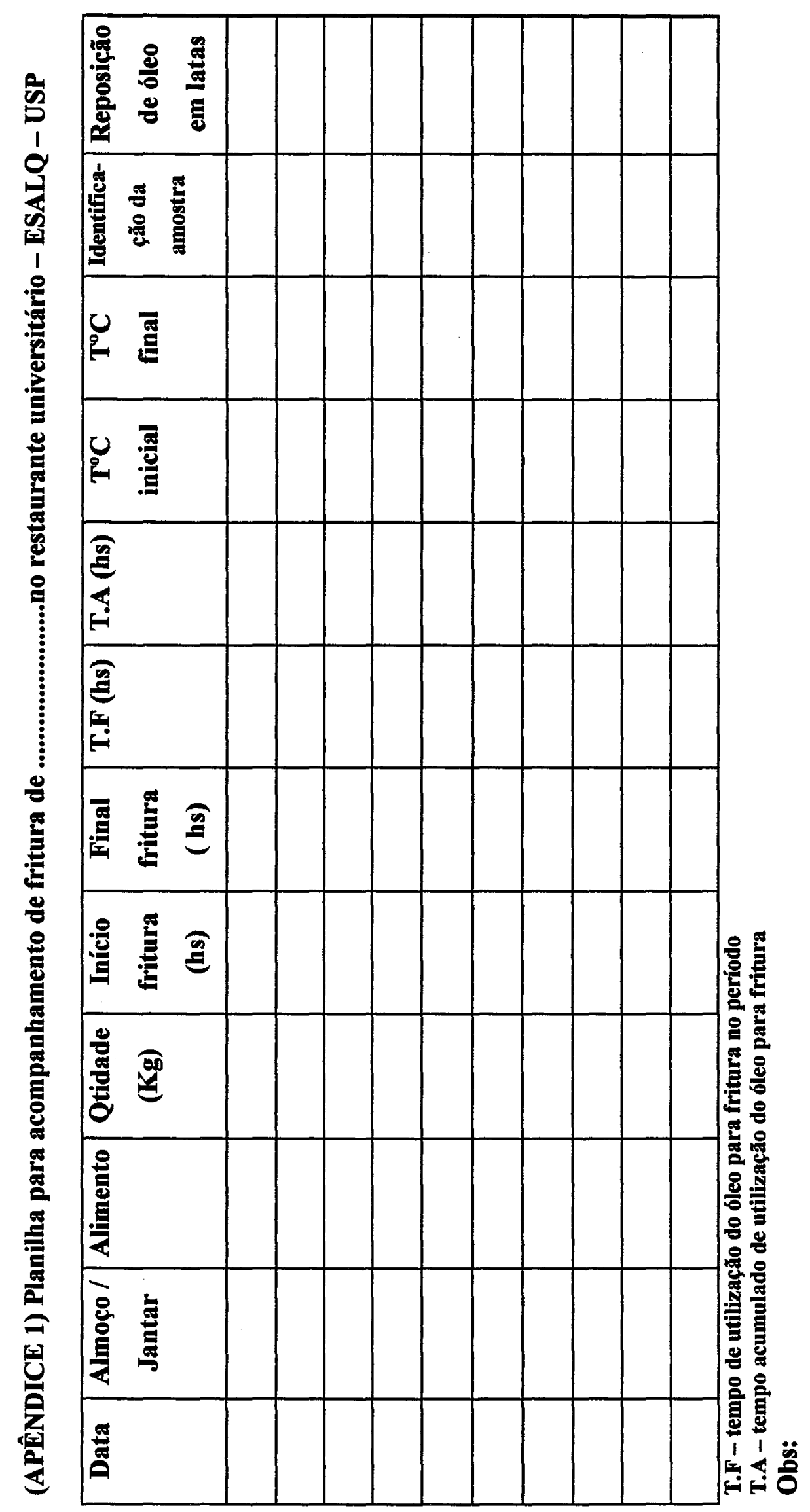




\section{Teste de aceitabilidade}

Nome.

Data

Por favor avalie a QUALIDADE DO ÓLEO usado na fritura de e diga sua preferência de acordo com a escala. Em seguida responda as questões abaixo. Obrigado.

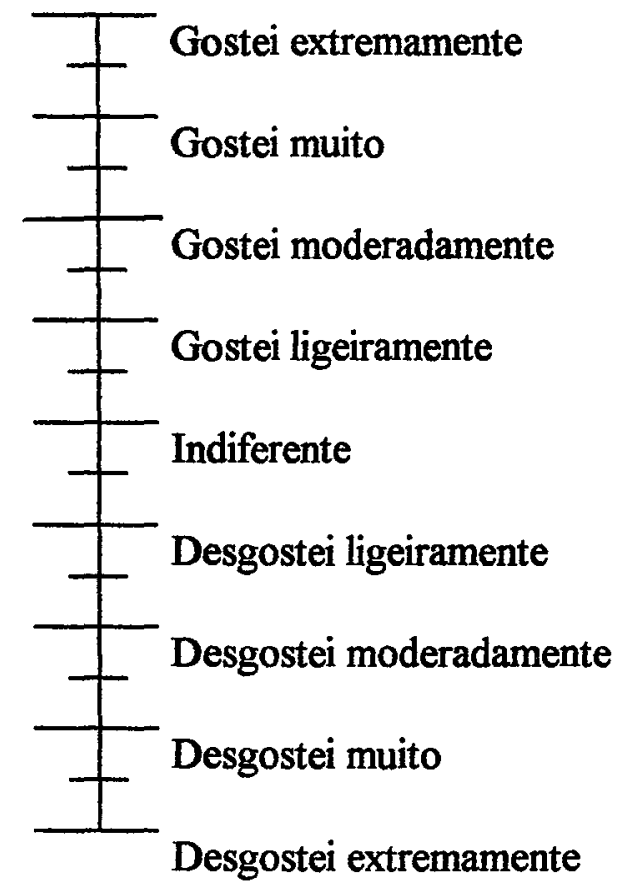

Porque gostei.

Porque desgostei.

Frequência de consumo: $($ ) frequentemente ( ) ocasionalmente $\quad($ ) nunca Em que locais consome este tipo de fritura: ( ) restaurante ( ) casa ( ) outros APÊNDICE 2 - Ficha utilizada no teste de aceitabilidade 